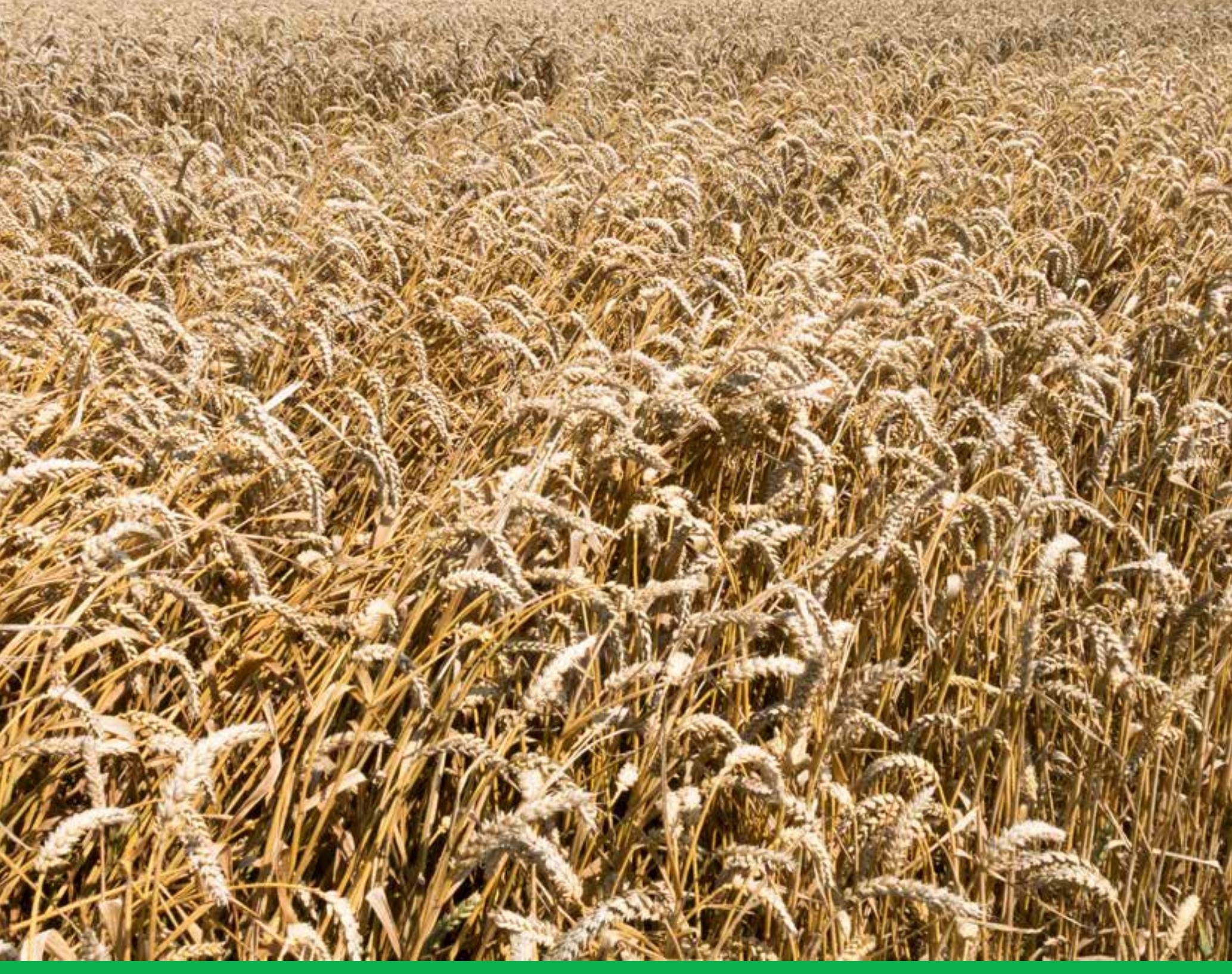

\title{
Economische betekenis van de grondgebonden landbouw in Zuid-Holland in 2016
}




\section{Economische betekenis van de grondgebonden landbouw in Zuid-Holland in 2016}

Theo Vogelzang, Bert Smit, Jakob Jager, David Verhoog, Janneke Vader en Jan-Willem van der Schans

Dit onderzoek is uitgevoerd door LEI Wageningen UR in opdracht van en gefinancierd door de provincie ZuidHolland.

LEI Wageningen UR

Wageningen, juni 2016

RAPPORT

LEI 2016-066

ISBN 978-94-6257-844-9

LE I 
Vogelzang, Theo, Bert Smit, Jakob Jager, David Verhoog, Janneke Vader en Jan-Willem van der Schans, 2016. Economische betekenis van de grondgebonden landbouw in Zuid-Holland in 2016. Wageningen, LEI Wageningen UR (University \& Research centre), LEI Report 2016-066. 54 blz.; 7 fig.; 12 tab.; 24 ref.

De sociaaleconomische positie van de grondgebonden landbouw in de provincie Zuid-Holland hangt deels samen met de perspectieven van het agrocluster, zijnde het totaal van land- en tuinbouwbedrijven, visserij, voedings- en genotmiddelenindustrie en de aan deze sectoren toeleverende bedrijven. Het belang van het grondgebonden landbouwcluster voor Zuid-Holland is in kaart gebracht, met een accent op de primaire sectoren en vooral de land- en tuinbouwbedrijven. De huidige situatie van deze bedrijven is in beeld gebracht, evenals de ontwikkelingen in de afgelopen tien jaar en de perspectieven voor de komende tien jaar. Daarnaast is specifiek gekeken naar de (economische) perspectieven van korte ketens en innovatie voor de grondgebonden landbouw in ZuidHolland.

The socio-economic future of agriculture in the Dutch province of Zuid-Holland is partly linked to the perspectives of the agrocluster, the combination of agricultural and horticultural firms, fishery, food and luxury industry and the firms that supply these sectors. The importance of this cluster for ZuidHolland is described, with a focus on the primary sectors, and especially on the agricultural firms. The current situation of these firms is presented, including the developments in the recent decade and the perspectives for the next decade. Attention is also paid to the (economic) perspectives of short supply chains and innovation for agriculture in Zuid-Holland.

Trefwoorden: Zuid-Holland, agrocluster, structuur grondbonden landbouw, perspectieven, korte ketens, innovatie.

Dit rapport is gratis te downloaden op http://dx.doi.org/10.18174/384970 of op www. wageningenUR.nl/lei (onder LEI publicaties).

(C) 2016 LEI Wageningen UR

Postbus 29703, 2502 LS Den Haag, T 07033583 30,E informatie.lei@wur.nl, www.wageningenUR.nl/lei. LEI is onderdeel van Wageningen UR (University \& Research centre).

\section{(cc) BY-NC}

LEI hanteert voor haar rapporten een Creative Commons Naamsvermelding 3.0 Nederland licentie.

(C) LEI, onderdeel van Stichting Dienst Landbouwkundig Onderzoek, 2016

De gebruiker mag het werk kopiëren, verspreiden en doorgeven en afgeleide werken maken. Materiaal van derden waarvan in het werk gebruik is gemaakt en waarop intellectuele eigendomsrechten berusten, mogen niet zonder voorafgaande toestemming van derden gebruikt worden. De gebruiker dient bij het werk de door de maker of de licentiegever aangegeven naam te vermelden, maar niet zodanig dat de indruk gewekt wordt dat zij daarmee instemmen met het werk van de gebruiker of het gebruik van het werk. De gebruiker mag het werk niet voor commerciële doeleinden gebruiken.

Het LEI aanvaardt geen aansprakelijkheid voor eventuele schade voortvloeiend uit het gebruik van de resultaten van dit onderzoek of de toepassing van de adviezen.

Het LEI is ISO 9001:2008 gecertificeerd.

LEI 2016-066 | Projectcode 2282700235

Foto omslag: Shutterstock 


\section{Inhoud}

Woord vooraf $\quad 5$

$\begin{array}{ll}\text { Samenvatting } & 6\end{array}$

S.1 Belangrijkste uitkomsten $\quad 6$

S.2 Overige uitkomsten $\quad 6$

$\begin{array}{ll}\text { S.3 Methode } & 7\end{array}$

$\begin{array}{ll}\text { Summary } & 8\end{array}$

$\begin{array}{lll}\text { S.1 Key findings } & 8\end{array}$

S.2 Complementary findings $\quad 8$

$\begin{array}{lll}\text { S.3 Method } & 9\end{array}$

1

$\begin{array}{lr}\text { Inleiding } & 10\end{array}$

$\begin{array}{llr}1.1 & \text { Aanleiding } & 10\end{array}$

$\begin{array}{lll}1.2 & \text { Probleemstelling } & 10\end{array}$

$\begin{array}{lll}1.3 & \text { Doelstelling } & 11\end{array}$

1.4 Aanpak 11

2

Structuurverkenning $\quad 12$

2.1 Inleiding $\quad 12$

$\begin{array}{lll}2.2 & \text { Structuur } & 12\end{array}$

$\begin{array}{lll}2.3 & \text { Bedrijfsomvang en inkomenspositie } & 18\end{array}$

$\begin{array}{lll}2.4 & \text { Conclusies } & 20\end{array}$

$3 \quad$ Het agrocluster in Zuid-Holland $\quad 22$

$\begin{array}{lll}3.1 & \text { Inleiding } & 22\end{array}$

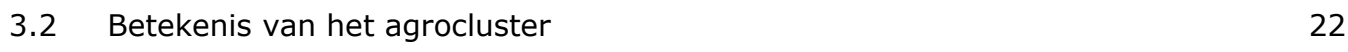

$\begin{array}{lll}3.3 & \text { Conclusies } & 25\end{array}$

$\begin{array}{llr}4 & \text { Innovatie } & \mathbf{2 7}\end{array}$

$\begin{array}{lll}4.1 & \text { Inleiding } & 27\end{array}$

$\begin{array}{lll}4.2 & \text { Innovatie in de Nederlandse land- en tuinbouw } & 27\end{array}$

$\begin{array}{lll}4.3 & \text { Innovatie } & 28\end{array}$

4.4 Trends en ontwikkelingen $\quad 32$

4.5 Mogelijkheden voor provinciaal beleid 33

$5 \quad$ Korte ketens $\quad 34$

$\begin{array}{lll}5.1 & \text { Inleiding } & 34\end{array}$

5.2 Ketenverkorting en -omkering 34

5.3 Groeiende betekenis van en kansen voor korte ketens 35

5.4 Gemeenschappelijk landbouwbeleid en korte ketens 37

$\begin{array}{lll}5.5 & \text { Conclusies } & 37\end{array}$

$6 \quad$ Toekomstperspectief voor de periode tot 202539

6.1 Toekomstverwachtingen per sector 39

6.2 Verwachte arealen, veestapel en aantallen bedrijven in 2025 
$\begin{array}{lll}7.1 & \text { Conclusies } & 42\end{array}$

$\begin{array}{lll}7.2 & \text { Aanbevelingen } & 43\end{array}$

$\begin{array}{ll}\text { Literatuur en websites } & 45\end{array}$

$\begin{array}{lll}\text { Bijlage } 1 & \text { Aanvullende structuurgegevens } & 47\end{array}$

Bijlage 2 Standaardopbrengst (SO) als maat voor de economische bedrijfsomvang in de land- en tuinbouw

Bijlage 3 Achtergrondinformatie bij de input-outputanalyse in hoofdstuk 352 


\section{Woord vooraf}

De grondgebonden landbouw in Zuid-Holland is op veel plaatsen beeldbepalend doordat een groot deel van de grond in de provincie door akkerbouw-, melkvee- en andersoortige grondgebonden agrarische bedrijven wordt gebruikt. Daarnaast is het grondgebonden agrocluster, zijnde de hele keten van toeleverende en verwerkende industrie rond deze grondgebonden primaire bedrijven, voor een relatief groot deel van de toegevoegde waarde en de werkgelegenheid in de provincie verantwoordelijk. De sociaaleconomische toekomst van de provincie Zuid-Holland hangt daarom voor een belangrijk deel samen met de perspectieven van het grondgebonden agrocluster. De leefbaarheid van het ZuidHollandse platteland wordt daarmee in sterke mate beïnvloed door de ontwikkelingen op en rond de primaire bedrijven.

De provincie Zuid-Holland heeft begin 2016 aangegeven dat er behoefte is aan een update van de verkenning voor de grondgebonden landbouw die het LEI in 2010 uitgevoerd heeft. Men achtte een dergelijke verkenning van belang voor de beleidsvorming van het College van Gedeputeerde Staten inzake de toekomst van de grondgebonden landbouw. Als specifieke aandachtspunten zijn de mogelijkheden voor korte ketens en innovatie in de komende jaren meegenomen.

Deze opdracht is aan LEI Wageningen UR verstrekt en dit rapport is in eerste helft van 2016 in nauwe interactie met een begeleidingsgroep vanuit de provincie Zuid-Holland tot stand gekomen, met als leden Jaap Halbersma, Hans Koot en Lucas Mutsaers. Hun nauwe en prettige betrokkenheid bij het onderzoek is door de onderzoekers zeer op prijs gesteld.

Namens het LEI is het onderzoek uitgevoerd door Theo Vogelzang (projectleider), Bert Smit (onderzoeker ondernemerschap, innovatie en duurzame akkerbouw), Jakob Jager (datavoorziening primaire sector), David Verhoog (datavoorziening en analyse agrocluster), Janneke Vader (korte ketens) en Jan-Willem van der Schans (korte ketens). Ten behoeve van het hoofdstuk korte ketens is een interne workshop georganiseerd, waaraan ook LEI-collega's Marc Ruijs, Harry Kortstee en Marijke Dijkshoorn-Dekker een bijdrage geleverd hebben. Hetzelfde was aan de orde voor het hoofdstuk innovatie, waarbij LEI-collega's Marie-José Smits, Trond Selnes en Gerben Splinter een inbreng geleverd hebben.

LEI Wageningen UR bedankt de provincie Zuid-Holland voor deze opdracht en voor de goede samenwerking.

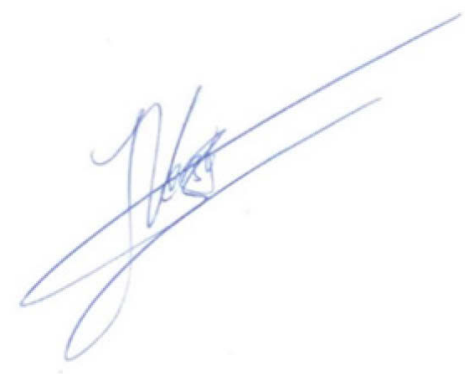

Prof. dr. ir. Jack (J.G.A.J.) van der Vorst

Algemeen Directeur SSG Wageningen UR 


\section{Samenvatting}

\section{S.1 Belangrijkste uitkomsten}

De grondgebonden landbouw in de provincie Zuid-Holland bestaat uit de sectoren (melk)veehouderij, akkerbouw en opengrondsgroententeelt. De bollenteelt wordt hier buiten beschouwing gelaten.

De structuur van de grondgebonden landbouw in de provincie Zuid-Holland is relatief gunstig, met name van de akkerbouw en melkveehouderij. Deze sectoren in Zuid-Holland zijn gemiddeld minder intensief dan in Nederland als geheel.

De primaire land- en tuinbouwsectoren spelen in Zuid-Holland een belangrijke rol in de totstandkoming van de totale toegevoegde waarde van het agrocluster. Voor het totale agrocluster in Zuid-Holland dragen de primaire agrarische sectoren en de voedings- en genotmiddelenindustrie gezamenlijk ruim $60 \%$ bij aan de totale toegevoegde waarde. De overige $40 \%$ is voor een groot deel gelieerd aan het glastuinbouwcomplex in deze provincie.

Het akkerbouwcluster draagt in Zuid-Holland met 31,5\% en bijna 27,5\% bij aan respectievelijk de toegevoegde waarde en de werkgelegenheid van het totale agrocluster in Zuid-Holland. Het totale akkerbouwcluster (inclusief de verwerking van buitenlandse grondstoffen) is in Zuid-Holland goed voor ruim 2,3 miljard euro toegevoegde waarde en bijna 24.000 arbeidsjaren werkgelegenheid. Hiervan hangt $18 \%$ samen met de productie en verwerking van binnenlandse akkerbouwproducten.

Het grondgebonden veehouderijcluster draagt in Zuid-Holland met 11,6 en $14,5 \%$ bij aan respectievelijk de toegevoegde waarde en de werkgelegenheid van het totale agrocluster in ZuidHolland. Op de primaire melkveehouderijbedrijven zelf wordt $12 \%$ van de toegevoegde waarde en $22 \%$ van de werkgelegenheid van dit cluster gerealiseerd. Wat betreft grondgebruik is het veehouderijcluster met ruim $60 \%$ het belangrijkste agrocluster in Zuid-Holland.

In Zuid-Holland zijn veel ondernemers en belanghebbende partijen actief inzake innovaties in de grondgebonden landbouw. De provincie heeft recent ook al invulling gegeven aan haar rol op dat gebied met het opstellen van het Ambitie-programma Duurzame Landbouw, waarmee de komende jaren financiële middelen beschikbaar komen voor systeeminnovaties in de sector. Daarmee wordt ruimte gecreëerd voor experimenten van agrarische ondernemers, maar ook voor het ontwikkelen van nieuwe verdienmodellen voor bijvoorbeeld stadslandbouw en korte ketens. Wel zijn er meer data en berekeningen nodig voor een inschatting van de mogelijke financiële inkomsten van dergelijke innovaties.

In Zuid-Holland is er bij betrokken partijen ook veel aandacht voor het opzetten en stimuleren van korte ketens. Om de ontwikkeling van korte ketens te stimuleren zou de provincie Zuid-Holland zich in eerste instantie kunnen richten op het ondersteunen van primaire producenten die zich organiseren in nieuwe coöperaties en producentenorganisaties. Zij zouden vanuit de provincie ook ondersteund kunnen worden bij het zoeken naar en het vormgeven van nieuwe verdienmodellen, onder andere via investeringssteun.

\section{S.2 Overige uitkomsten}

De provincie Zuid-Holland zou innovatie in de grondgebonden landbouw in haar regio meer ruimte kunnen geven door middel van de volgende (stimulerings)maatregelen:

- stimuleren en faciliteren van experimenten door boeren

- grootschalige adoptie van ICT en inzetten op Big Data, ook om duurzaamheid te managen (onder andere via precisielandbouw) 
- meer co-creatie tussen consumenten en producenten, onder andere via het stimuleren van korte ketens

- het creëren van financiële en organisatorische ruimte voor de betrokken ondernemers om nieuwe verdienmodellen te ontwikkelen.

\section{Aanbevelingen}

- inzet van het EIP uit het Plattelandsontwikkelingsprogramma (POP3) voor innovatie ten aanzien van samenwerking tussen ondernemers en het opzetten van kenniskringen voor innovaties

- investeringssteun voor innovatieve bedrijven

- garantstelling voor investeringen van agrarische ondernemers in innovaties.

\section{Overige aanbevelingen}

- Organiseer de ruimtelijke ordening in de provincie Zuid-Holland meer flexibel om korte ketens meer kansen te geven.

- Verruim in dat kader ook de interpretatie van het begrip 'huisverkoop', zodat daar meer activiteiten onder kunnen vallen.

- Ondersteun de infrastructurele ontsluiting van betrokken bedrijven, zodat er mee ruimte is voor logistieke bewegingen die noodzakelijk zijn om korte ketens meer kansen te geven.

- Zet zowel de provincie als betrokken kennisinstellingen meer in op gegevensverzameling ten aanzien van de opbouw en de (economische) inkomsten van zowel innovatie als korte ketens in de grondgebonden landbouw.

\section{S.3 Methode}

$\mathrm{Er}$ is aandacht besteed aan de volgende hoofdonderwerpen:

1. De huidige en toekomstige structuur van de grondgebonden landbouw in Zuid-Holland.

2. De economische betekenis van het grondgebonden agrocluster in de provincie.

3. Verwachte trends en ontwikkelingen inzake innovatie in de grondgebonden landbouw in de provincie.

4. Verwachte trends en ontwikkelingen inzake korte ketens in de provincie.

5. Advies aan de provincie.

Voor de onderdelen 1 en 2 zijn data verzameld, geanalyseerd en gerapporteerd uit verschillende bronnen, zoals de Landbouwtelling van het CBS en het Bedrijveninformatienet (Informatienet) van het LEI. Daarbij zijn verschillende structuur- en inkomensindicatoren in beeld gebracht voor de jaren 2003, 2008, 2013 en 2015 voor Zuid-Holland en voor Nederland als geheel. Hoewel de vraag van de provincie was om dit te doen voor de periode van 2008 tot en met 2015, is hier gekozen voor perioden van 5 jaar omdat die meer onderscheidend zijn.

De betekenis van het agrocluster, onderdeel 2, is in beeld gebracht door een provinciale inputoutputanalyse uit te voeren, gebruik makend van regionale LISA-gegevens (bron: Kamer van Koophandel).

De verwachte trends en ontwikkelingen inzake innovatie in de grondgebonden landbouw in Zuid-Holland, onderdeel 3, zijn in kaart gebracht door ontwikkelingen op dit gebied binnen en buiten Zuid-Holland te vertalen naar hun mogelijke invloed op de trends in Zuid-Holland zelf. Voor een inschatting van het economische perspectief van innovatie in de grondgebonden landbouw, nu en in de toekomst, is meer vervolgonderzoek vereist.

De verwachte trends en ontwikkelingen inzake korte ketens in de grondgebonden landbouw in Zuid-Holland, onderdeel 4, zijn in kaart gebracht door ontwikkelingen binnen en buiten Zuid-Holland te vertalen naar hun mogelijke invloed op de trends in Zuid-Holland zelf. Ook hier is getracht om een inschatting te maken van het economische perspectief van deze ketens, nu en in de toekomst, maar ook hierbij is geconcludeerd is dat dit vervolgonderzoek vereist.

De studie sluit af met conclusies en aanbevelingen. 


\section{Summary}

\section{S.1 Key findings}

Land-based agriculture in the province of South Holland consists of three sectors: livestock and dairy farming, arable farming and open air vegetable cultivation. Bulb cultivation has not been included in this report.

The structure of land-based agriculture in South Holland is fairly favourable, especially for arable farming and dairy farming. On average, these sectors are less intensive in South Holland than in the rest of the Netherlands.

The primary agricultural and horticultural sectors in South Holland make an important contribution to the total added value of the agro-cluster. The primary agricultural sectors and the food and beverages industry together make up just over $60 \%$ of the total added value of the entire agro-cluster. The other $40 \%$ is largely made up by the greenhouse horticulture complex in the province.

The arable farming cluster creates $31.5 \%$ of the added value and nearly $27.5 \%$ of employment opportunities of the entire agro-cluster in South Holland. The entire arable farming cluster (including the processing of imported raw materials) in South Holland is worth 2.3 billion euros of added value and nearly 24,000 annual labour units. $18 \%$ of this is related to the production and processing of domestic arable farming products.

The land-based livestock farming cluster contributes $11.6 \%$ to the added value and $14.5 \%$ to employment opportunities of the total agro-cluster in South Holland. At primary dairy farms this amounts to $12 \%$ of the added value and $22 \%$ of the employment opportunities of this cluster. With regard to land use, the livestock farming cluster, which uses over $60 \%$ of the land, is the most important agro-cluster in South Holland.

Many businesses and stakeholders in South Holland are involved with innovations in land-based agriculture. Recently, the province also made a contribution to land-based agriculture by setting up the Sustainable Agriculture ambition programme which will make financial resources available for the development of system innovations in this sector in the next few years. This makes experiments by farmers possible and also helps to develop new revenue models for urban agriculture and short chains. More data and calculations are required to make an estimation about the possible financial revenues of such innovations.

Stakeholders in South Holland are also focusing on creating and stimulating short chains. In order to stimulate the development of short chains, South Holland should first focus on supporting primary producers who have organised into new cooperatives and producers' organisations. The province should also support them in exploring and creating new revenue models through investment aid for example.

\section{S.2 Complementary findings}

The province of South Holland could create more opportunities for innovation in land-based agriculture through the following stimulating measures:

- Stimulating and facilitating experiments by farmers

- Large-scale implementation of ICT and focusing on big data which will also help to manage sustainability (through precision farming, for instance) 
- More co-creation between consumers and producers through stimulating short chains and other measures

- Creating financial and organisational opportunities for involved businesses to develop new revenue models

\section{Recommendations}

- Implementing the Entrepreneurship and Innovation Programme (EIP) from the third rural development programme (POP3) for innovations relating to collaborations between businesses and setting up knowledge networks for innovations

- Investment aid for innovate businesses

- Guarantees for investments of farmers in innovations

\section{Other recommendations}

- Increase the flexible organisation of spatial planning in South Holland to give short chains more opportunities

- Expand the interpretation of the concept of sales from the farmhouse to include more activities

- Support the infrastructural expansion of involved businesses so that there is more space for the logistical movements that are needed to give short chains more opportunities

- The province and involved knowledge institutes should focus more on data collection for the advancement and economic revenue of innovation and short chains in land-based agriculture

\section{S.3 Method}

The following main topics have been addressed:

1. The current and future structure of land-based agriculture in South Holland.

2. The economic importance of the land-based agro-cluster in the province.

3. Expected trends and developments regarding innovation in land-based agriculture in the province.

4. Expected trends and developments for short chains in the province.

5. Recommendations for the province.

Data has been collected, analysed and cited from different sources such as the Agricultural Census of Statistics Netherlands (CBS) and the LEI Wageningen UR Farm Accountancy Data Network (FADN) for parts 1 and 2. In addition, various structural and revenue indicators have been identified for 2003, 2008, 2013 and 2015 for South Holland and the Netherlands as a whole. Although the province had requested that this be done for the period from 2008 up to and including 2015, the choice was made to use periods of five years each, as they are more distinctive.

The importance of the agro-cluster, part 2, is demonstrated by conducting a provincial input and output analysis that makes use of regional data from the Landelijk Informatiesysteem van Arbeidsplaatsen (national database of work locations, LISA) (source: Dutch Chamber of Commerce).

The expected trends and developments in innovation in land-based agriculture in South Holland, part 3, are expounded by translating developments in this field within and outside South Holland into their possible impact on trends in the province itself. More follow-up research is required for an estimation of the economic prospects of innovation in land-based agriculture, now and in the future.

The expected trends and developments in short chains in land-based agriculture in South Holland, part 4, are expounded by translating developments in this field within and outside South Holland into their possible impact on trends in the province itself. An attempt was made to make an estimation about the economic prospects of these chains, now and in the future. However, it was concluded that this would also require further research.

Finally, the study presents its conclusions and recommendations. 


\section{$1 \quad$ Inleiding}

\section{$1.1 \quad$ Aanleiding}

Het LEI is door de Provincie Zuid-Holland verzocht om een update te maken van LEI-rapport 2010-007, De grondgebonden landbouw in Zuid-Holland; Structuur en ontwikkeling (Blokland et al., 2010). Deze update betrof de volgende punten:

1. De thermometer: ofwel de huidige staat van de grondgebonden landbouw in Zuid-Holland. Hierbij werd ook de stand van zaken in het agrocluster betrokken. Het LEI werd gevraagd inzicht te geven in:

- de ontwikkeling van de werkgelegenheid in de grondgebonden landbouw in de provincie tussen 2008 en 2016, met name voor de sectoren melkveehouderij, akkerbouw en vollegrondsgroenteteelt, ook in relatieve zin

- de toegevoegde waarde die deze sectoren anno 2016 genereren

- de leeftijd van de actieve ondernemers in deze sectoren, inclusief opvolgingssituatie

- de inkomensontwikkeling op de grondgebonden agrarische bedrijven in de provincie

- de toegevoegde waarde van en de werkgelegenheid in het grondgebonden agrocluster in Zuid-Holland.

Het ging hierbij om trends en ontwikkelingen gedurende een reeks van jaren, op basis van eerdere LEI-rapportages. Aanvullend werd gevraagd om een korte duiding te geven van de betekenis van de bovengenoemde ontwikkelingen richting 2025;

2. Trends en ontwikkelingen inzake innovatie in de grondgebonden landbouw in de provincie: wat is de economische betekenis van, of wat kan de economische betekenis zijn van, innovatie in de grondgebonden landbouw in Zuid-Holland? Kan het innovatieve karakter van de grondgebonden landbouw in Zuid-Holland worden aangegeven met een aantal indicatoren, die in de loop van de jaren ook bijgehouden kunnen worden?

3. Trends en ontwikkelingen in de korte ketens in Zuid-Holland: wat is de economische betekenis van, of wat kan de economische betekenis zijn van, korte ketens in de grondgebonden landbouw in Zuid-Holland; ofwel wat is de economische potentie van die korte ketens en wat zijn de voorwaarden om die potentie te benutten?

\subsection{Probleemstelling}

De provincie Zuid-Holland heeft in het voorjaar van 2016 aangegeven dat er behoefte is aan actueel inzicht in de economische betekenis van de grondgebonden landbouw in haar regio. Men achtte een dergelijke verkenning van belang ter voorbereiding van het Ambitiedocument Duurzame Landbouw in Zuid-Holland, dat GS in juni 2016 aan PS wil presenteren.

In 2010 heeft het LEI voor de provincie Zuid-Holland een rapport opgesteld over de structuur en ontwikkeling van de grondgebonden landbouw op haar grondgebied (LEI-rapport 2010-007). Begin 2016 bleek dat er bij de provincie behoefte was aan een update van (gedeelten) uit dat rapport. Daarnaast wilde de provincie graag een analyse en een visie van het LEI op de twee thema's 'innovatie' en 'korte ketens' met betrekking tot de toekomst van de land- en tuinbouwsector in haar regio.

De kernvraag in dit onderzoek was dan ook:

'Wat is het economische belang van de grondgebonden landbouw en het daaraan verbonden agrocluster in de provincie Zuid-Holland en wat kunnen innovatie en korte ketens daaraan bijdragen?' 


\subsection{Doelstelling}

Het doel van deze verkenning was om de provincie een helder beeld te laten krijgen van:

1. De economische betekenis van de grondgebonden landbouw en het bijbehorende agrocluster in Zuid-Holland in 2016.

2. De economische potentie van innovatie en de toekomst van korte ketens in de grondgebonden landbouw in Zuid-Holland.

Dit beeld was nodig als bouwsteen voor het Ambitiedocument Duurzame Landbouw in Zuid-Holland, dat GS in juni 2016 aan PS heeft gepresenteerd.

\subsection{Aanpak}

De volgende activiteiten c.q. methodieken zijn uitgevoerd of gebruikt. Per onderdeel ging het daarbij om:

1. De thermometer: voor dit onderdeel werden vooral databronnen geraadpleegd om de genoemde thema's voor de sector en het agrocluster in Zuid-Holland in beeld te brengen. Daarbij ging het onder andere om de CBS-Landbouwtelling, het Bedrijveninformatienet (Informatienet) van het LEI en LISA-gegevens.

2. Verwachte trends en ontwikkelingen inzake de onderwerpen innovatie en korte ketens in de grondgebonden landbouw in Zuid-Holland; een bespreking met LEI-deskundigen en (beperkte) literatuurstudie vormden in deze fase bij beide onderwerpen de belangrijkste activiteiten;

3. Conclusies en aanbevelingen. 


\section{$2 \quad$ Structuurverkenning}

\section{$2.1 \quad$ Inleiding}

Dit hoofdstuk beschrijft de structuur van de grondgebonden landbouw in Zuid-Holland en de ontwikkelingen die daarin de afgelopen jaren hebben plaatsgevonden. Na een schets van het totaalbeeld van de arealen voor de verschillende sectoren in Zuid-Holland gaan we in op de stand van zaken en de ontwikkelingen in die sectoren. Vervolgens wordt aandacht besteed aan de schaalvergroting in de provincie en wordt ook bezien hoe de opvolgingssituatie in de sector eruitziet. We eindigen dit hoofdstuk met een overzicht van de inkomensontwikkeling en de saldi in de verschillende sectoren. In alle gevallen wordt ook een vergelijking gemaakt met de situatie in Nederland als geheel of met andere vergelijkbare landbouwgebieden in Nederland.

\subsection{Structuur}

\section{Meeste grondgebonden bedrijven zijn melkvee-, graasdier- of akkerbouwbedrijven}

In de provincie Zuid-Holland zijn de melkveehouderij, de overige graasdierbedrijven en de akkerbouwbedrijven qua aantallen bedrijven de grootste grondgebonden sectoren. In Tabel 2.1 is het aantal bedrijven in verschillende grondgebonden sectoren weergegeven in zowel de provincie Zuid-Holland als Nederland als geheel. In 2015 telde Nederland 64.000 land- en tuinbouwbedrijven, waarvan er $9 \%$ in de provincie Zuid-Holland lagen. Van die 64.000 bedrijven behoorden er 49.000 , ofwel 76\%, tot de grondgebonden bedrijfstypen. Zuid-Holland telde in 2015 een kleine 3.400 grondgebonden bedrijven op een totaal van ruim 5.800 land- en tuinbouwbedrijven, ofwel $58 \%$. Er zijn in de provincie relatief veel niet-grondgebonden bedrijven, met name glastuinbouwbedrijven. Dit blijkt ook uit het feit dat zich in deze provincie $16 \%$ van de niet-grondgebonden bedrijven bevindt. Het aantal opengrondsgroentebedrijven is daarentegen vrij gering, namelijk 34 ofwel $4 \%$ van het nationale aantal.

In Zuid-Holland bevindt zich $7 \%$ van het totaal aantal grondgebonden bedrijven in Nederland. Daarbij gaat het vooral om melkveebedrijven (ruim 1.200), overige graasdierbedrijven (eveneens ruim 1.200; het gaat hierbij om bedrijven met andere graasdieren dan melkkoeien, zoals jongvee, schapen, vleesen zoogkoeien) en akkerbouwbedrijven. In Zuid-Holland zijn dus de melkveehouderij, de overige graasdier-bedrijven en de akkerbouwbedrijven qua aantallen bedrijven de grootste grondgebonden sectoren. Zie voor het overzicht Tabel 2.1.

Tabel 2.1

Aantal land- en tuinbouwbedrijven in Zuid-Holland en Nederland in 2015 naar bedrijfstype

\begin{tabular}{|c|c|c|c|}
\hline \multirow[t]{2}{*}{ Bedrijfstype } & \multicolumn{2}{|c|}{ Aantal bedrijven in regio: } & \multirow[t]{2}{*}{ Aandeel ZH in totaal $(\%)$} \\
\hline & Zuid-Holland & Nederland & \\
\hline Melkvee & 1.215 & 16.697 & 7 \\
\hline Opengrondsgroente & 34 & 961 & 4 \\
\hline Overige graasdieren & 1.211 & 15.704 & 8 \\
\hline Totaal aantal bedrijven & 5.839 & 63.915 & 9 \\
\hline Totaal grondgebonden c) & 3.364 & 48.836 & 7 \\
\hline
\end{tabular}

a) Gemengde bedrijven hebben meerdere takken op hun bedrijf, bijvoorbeeld akkerbouw en melkvee;

b) Overige bedrijven vallen onder de types hokdieren, tuinbouw en blijvende teelten;

c) Totaal grondgebonden zijn alle typen behalve de overige bedrijven.

Bron: CBS, Landbouwtelling 2015. 
Tabel 2.1 geeft de aantallen bedrijven in 2015. Die aantallen zijn voor alle bedrijfstypen lager dan in 2003, zowel in Zuid-Holland als nationaal, maar er zijn grote verschillen tussen bedrijfstypen

(Figuur B1.1).

Het totaal aantal grondgebonden bedrijven in zowel Zuid-Holland als Nederland als geheel is in de afgelopen 12 jaar met $20 \%$ gedaald. Opvallend is de daling van het aantal opengrondsgroentebedrijven (33\% in Nederland, $66 \%$ in Zuid-Holland) en van het aantal gemengde bedrijven (een halvering op zowel provinciaal als nationaal niveau). Het aantal melkvee- en akkerbouwbedrijven is met ongeveer $20 \%$ gedaald. Dat is voor de melkveehouderij even sterk als in Nederland als geheel, maar voor de akkerbouw is de daling dubbel zo groot als nationaal gezien. Voor de overige graasdierbedrijven geldt het omgekeerde. Bij dat bedrijfstype is het aantal bedrijven nationaal met bijna 20\% gedaald maar provinciaal vrijwel constant gebleven. Deze ontwikkelingen vertalen zich ook in werkgelegenheid op de verschillende bedrijfstypen (zie hieronder). De aantallen bedrijven zijn dus voor alle bedrijfstypen lager dan in 2003, zowel in Zuid-Holland als nationaal. Er zijn echter grote verschillen tussen bedrijfstypen, variërend tussen $-2 \%$ bij graasdierbedrijven tot - $66 \%$ bij opengronds-groentebedrijven.

\section{Relatief veel werkgelegenheid op melkvee-, graasdier- en akkerbouwbedrijven}

Agrarische bedrijvigheid brengt werkgelegenheid met zich mee, zowel op de agrarische bedrijven zelf als in de rest van de agroketen. Het belang van de verschillende ketenpartijen wordt in hoofdstuk 3 toegelicht aan de hand van een input-outputtabel; in dit hoofdstuk gaat het om de werkgelegenheid op de grondgebonden bedrijven zelf, bestaande uit de ondernemer zelf en eventuele meewerkende gezinsleden, vaste en tijdelijke medewerkers.

In Figuur 2.2 is de werkgelegenheid in de verschillende grondgebonden bedrijfstypen in de provincie Zuid-Holland weergegeven in de jaren 2003, 2008, 2013 en 2015. De exacte data bij deze figuur zijn weergegeven in Tabel B1.1). Er blijft ten opzichte van Nederland als geheel in Zuid-Holland relatief veel werkgelegenheid op melkvee-, graasdier- en akkerbouwbedrijven. De opengrondsgroente- en gemengde bedrijven toonden daarbij de grootste daling in die periode.

De totale werkgelegenheid op grondgebonden bedrijven in Zuid-Holland vertoont sinds 2003 een dalende trend. Het totaal aantal arbeidsjaareenheden in de grondgebonden sectoren bedroeg in dat jaar nog ruim 6.600 en daalde naar ruim 5.700 in 2015, een daling van bijna $15 \%$. Alleen op de overige graasdier-bedrijven is de werkgelegenheid sinds 2003 toegenomen, namelijk met meer dan $20 \%$. De meeste werkgelegenheid bevindt zich op melkveebedrijven. Maar op die bedrijven is de werkgelegenheid sinds 2003 in absolute termen ook het sterkst gedaald, namelijk met ruim 500 arbeidsjaareenheden. Relatief gezien is de daling het sterkst geweest op de opengrondsgroentebedrijven, namelijk met meer dan $50 \%$.

De meeste werkgelegenheid bevindt zich, na de melkveebedrijven, op de overige graasdier- en akkerbouwbedrijven in Zuid-Holland. Opvallend is in de provincie de omvang van de overige graasdier-bedrijven, zowel in aantallen bedrijven als in werkgelegenheid. Dit bedrijfstype is over het algemeen minder intensief dan de melkveehouderij, maar blijkbaar vindt er op de overige graasdierbedrijven in Zuid-Holland veel economische activiteit plaats. Dit is ook wel te verklaren gezien het aantal bedrijven dat in de provincie in deze sector actief is.

\section{Tabel 2.2}

Ontwikkeling van de werkgelegenheid in de periode 2003-2015 op grondgebonden bedrijfstypen in Zuid-Holland

\begin{tabular}{|c|c|c|c|c|}
\hline \multirow[t]{2}{*}{ Bedrijfstype } & \multicolumn{4}{|c|}{ Werkgelegenheid (totaal aantal arbeids-jaareenheden) in jaar: } \\
\hline & 2003 & 2008 & 2013 & 2015 \\
\hline Melkvee & 3.096 & 2.758 & 2.596 & 2.579 \\
\hline Akkerbouw & 1.280 & 1.064 & 1.042 & 1.078 \\
\hline Opengrondsgroente & 241 & 150 & 118 & 99 \\
\hline Overige graasdieren & 1.339 & 1.700 & 1.717 & 1.630 \\
\hline Gemengde bedrijven & 691 & 516 & 348 & 361 \\
\hline
\end{tabular}




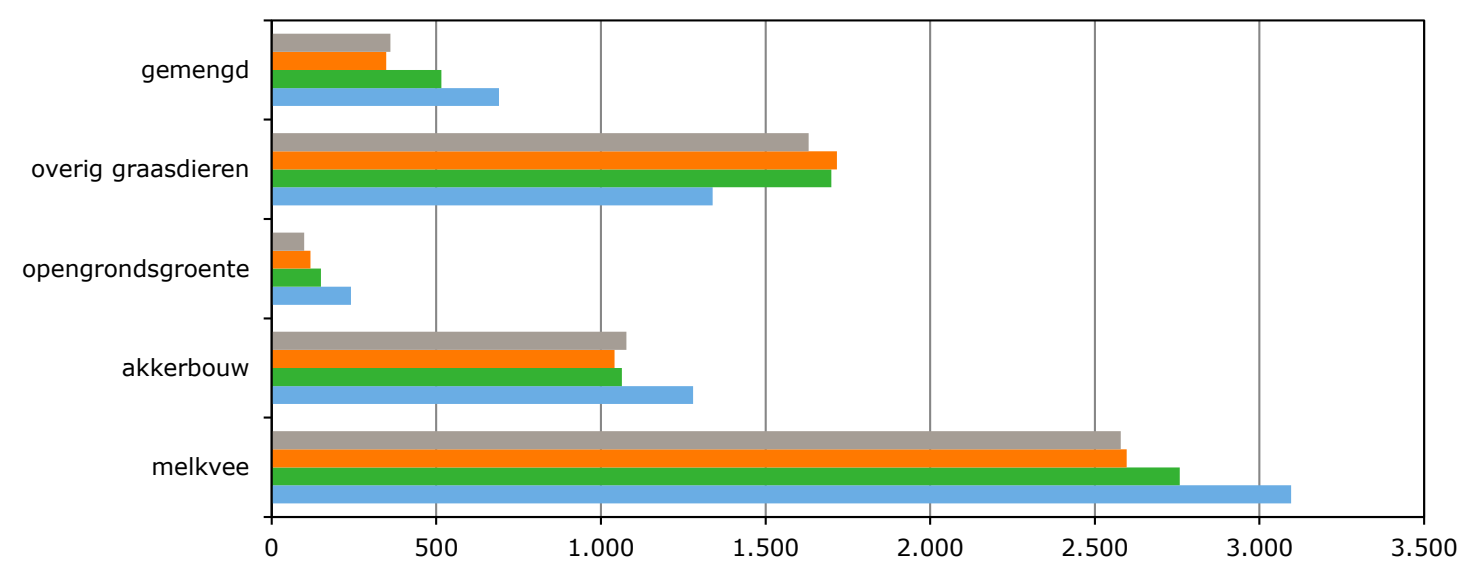

$2015-2013=2008-2003$

Figuur 2.1 Werkgelegenheid op grondgebonden bedrijfstypen in Zuid-Holland in 2003, 2008, 2013 en 2015

Bron: CBS, Landbouwtelling, diverse jaren.

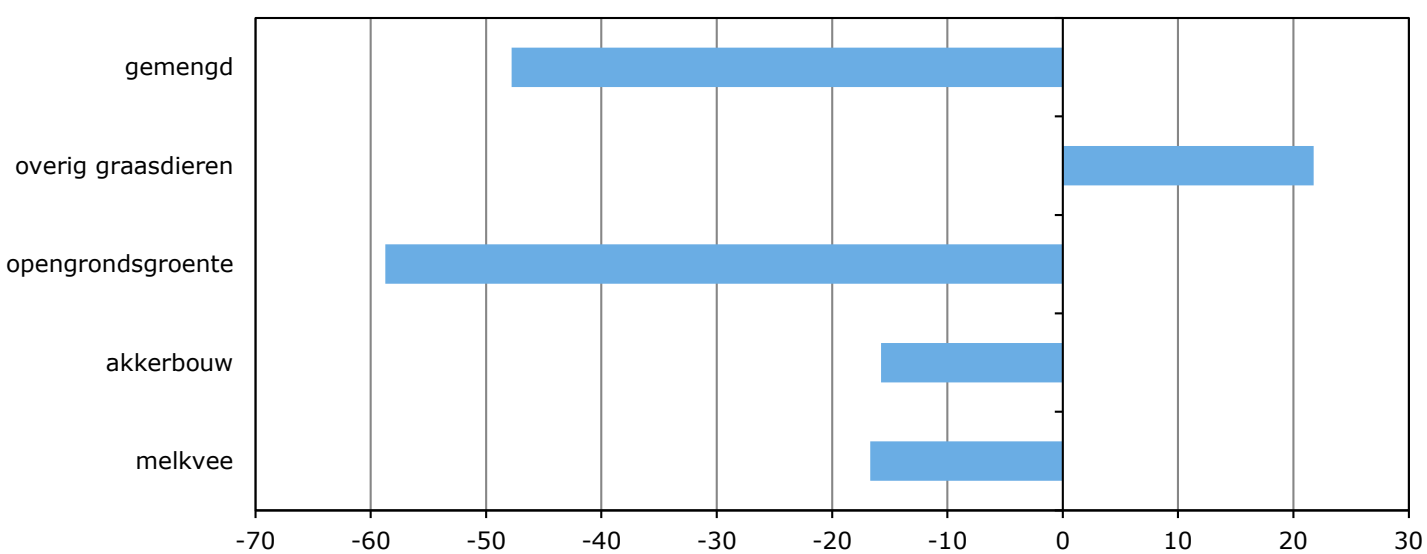

Figuur 2.2 Ontwikkeling van de werkgelegenheid op grondgebonden bedrijfstypen in Zuid-Holland in 2015 ten opzichte van 2003 (in \%; 2003=100)

Bron: CBS, Landbouwtelling, diverse jaren.

\section{Meer groenvoedergewassen en granen, melkkoeien, jongvee en geiten in Zuid-Holland} In de bijlagen wordt ook informatie gegeven over de gewasarealen en dieraantallen in de provincie. Figuur B1.2 toont de arealen grondgebonden gewassen in de jaren 2003, 2008, 2013 en 2015. Het totale areaal grondgebonden gewassen is sinds 2003 in Zuid-Holland afgenomen. Dat geldt ook voor de meeste afzonderlijk weergegeven gewassen of gewasgroepen, maar bij groenvoedergewassen en granen zijn de arealen tussen 2003 en 2015 licht toegenomen.

Grasland beslaat met 68.000 ha het grootste areaal in Zuid-Holland, wat mede verklaarbaar is door de grote omvang van de veenweidegebieden in het Zuid-Hollandse deel van het Groene Hart. Daarbij aansluitend wordt in de provincie ongeveer 12.000 ha groenvoedergewassen geteeld, met name snijmais. Bij de akkerbouwgewassen vallen met name de granen met ruim 15.000 ha en de aardappelen met 10.000 ha op. Deze gewassen worden met name geteeld op de Zuid-Hollandse 
eilanden en in de droogmakerijen. De opengrondsgroentesector heeft met 12.500 ha ook een significant aandeel van de grond in gebruik.

Het totale areaal grondgebonden gewassen is dus sinds 2003 in Zuid-Holland afgenomen. Dat geldt in lichte mate ook voor grasland, maar dat is wel het belangrijkste gewas in Zuid-Holland gebleven.

Figuur B1.3 in Bijlage 1 bij dit rapport laat de absolute ontwikkeling van het aantal dieren per diersoort zien sinds 2003. Zuid-Holland telt relatief veel melkkoeien, jongvee en schapen en lammeren. De aantallen melkkoeien, jongvee en geiten zijn (licht) toegenomen. De aantallen vleesrunderen, paarden/pony's en schapen zijn afgenomen. In de provincie Zuid-Holland bevinden zich ongeveer 100.000 melkkoeien, maar het aantal schapen en lammeren is groter, bijna 110.000. Dit aantal neemt evenwel trendmatig af, met in 2003 nog meer dan 135.000 schapen en lammeren. Het aantal stuks jongvee tussen 0 en 2 jaar bedraagt in totaal ruim 70.000. Het belang daarvan is duidelijk groter dan van vleesrunderen, waarvan het aantal gedaald is naar minder dan 14.000. Het aantal geiten is de afgelopen jaren met meer dan 5.000 dieren toegenomen, wat een stijging van meer dan $50 \%$ betekent.

Zuid-Holland telt dus relatief veel melkkoeien, jongvee en schapen en lammeren. De aantallen melkkoeien, jongvee en geiten nemen in de loop van de jaren toe. Bij vleesrunderen, paarden/pony's en schapen is een afname te zien.

\section{Meer dan de helft van de grond in eigendom}

Het benodigde vermogen om een bedrijf te kunnen runnen hangt met name in de grondgebonden sectoren van de land- en tuinbouw sterk samen met de vraag of de ondernemer de grond in eigendom heeft of die geheel of gedeeltelijk kan pachten. De hoge grondprijzen in Nederland, zeker ook in ZuidHolland, leiden tot een hoge financieringsbehoefte en een hoge schuldenlast van de grondgebonden land- en tuinbouwbedrijven. Figuur B1.4 geeft aan welk deel van de grond in Zuid-Holland in eigendom, pacht of erfpacht wordt ingezet. Meer dan de helft van de grond blijkt in eigendom te zijn.

Het areaal erfpacht in de provincie is ongeveer 1.000 ha en vrij constant. Van de in totaal ruim 125.000 ha land- en tuinbouwgrond op grondgebonden bedrijven was in 201570.000 ha ofwel 56\% eigendom en de resterende 55.000 ha of $44 \%$ pacht. Het totale landbouwareaal is sinds 2014 afgenomen van meer dan 140.000 naar minder dan 130.000 ha. Met name het areaal grond in eigendom is gedaald. Maar nog steeds is meer dan de helft van de grond in eigendom.

\section{Minder eigendom in melkveehouderij, meer in akkerbouw}

Bovenstaande informatie over eigendom en pacht is ook nader uitgesplitst naar melkveehouderij en akkerbouw. Dan blijkt dat het aandeel eigendom in de melkveehouderij sinds 2003 is gedaald en in de akkerbouw gestegen.

In Figuur B1.5 en Tabel B1.1 (in de bijlagen) is de verdeling tussen pacht, erfpacht en eigendom weergegeven in 2003, 2008, 2013 en 2015 voor de melkveehouderij in Zuid-Holland. In deze sector is tussen 2003 en 2015 het aandeel grond in eigendom afgenomen van 67 naar 64\%. Blijkbaar is dit een nationale trend, want gemiddeld voor Nederland is dit aandeel van 65 naar $64 \%$ gegaan.

In Figuur B1.6 en Tabel B1.2 (in de bijlagen) is de verdeling tussen pacht, erfpacht en eigendom weergegeven in 2003, 2008, 2013 en 2015 voor de akkerbouw in Zuid-Holland. Opvallend is dat in deze sector tussen 2003 en 2015 het aandeel grond in eigendom juist toegenomen is, namelijk van 49 naar 55\%. Blijkbaar is ook dit een nationale trend, want gemiddeld voor Nederland is dit aandeel van 51 naar $57 \%$ gegaan. In de melkveehouderij is dus de afgelopen jaren het aandeel eigendom afgenomen en in de akkerbouw juist toegenomen. ${ }^{1}$

\footnotetext{
1 Het totaal aandeel eigendom in Zuid-Holland over alle bedrijfstypen ging tussen 2003 en 2015 van 60 naar 55\%. Voor Nederland als geheel ging dit van 59 naar $58 \%$. Met name bij de overige graasdieren daalde het aandeel eigendom sterk (meer dan 10\%), zowel in Zuid-Holland als in Nederland. Op biologische bedrijven is er landelijk geen daling van het aandeel eigendom (wel is het niveau lager met 41\%), maar in Zuid-Holland is het aandeel op biologische bedrijven sterker gezakt dan op alle bedrijven (respectievelijk 11 en 5\%).
} 


\section{Leeftijdsopbouw: vergrijzing in alle sectoren}

Figuur 2.3 toont de leeftijdsopbouw in de grondgebonden bedrijfstypen in Zuid-Holland in 2000, 2004, 2008, 2012 en 2015. Het blijkt dat in alle sectoren vergrijzing optreedt. Opvallend is dat bij alle bedrijfstypen in 201560 tot soms $80 \%$ van de ondernemers 50 jaar of ouder is. In de akkerbouw (30\%) en op de overige graasdierbedrijven (40\%) is een significant aandeel van de ondernemers zelfs $65^{+}$. Bij de melkveehouders en de opengrondsgroentetelers zijn deze percentages kleiner (15\%), waarschijnlijk omdat in deze sectoren het werk fysiek zwaarder is. Gemiddeld was in 2012 slechts $10 \%$ van de ondernemers jonger dan 40 jaar en $30 \%$ jonger dan 50 jaar. Op de overige graasdierbedrijven ${ }^{2}$ was het aantal ondernemers jonger dan 50 jaar zelfs minder dan een kwart. Er treedt in de weergegeven jaren een verschuiving op naar hogere leeftijden, zodat sprake is van vergrijzing. Dat betekent overigens niet dat er grond buiten gebruik geraakt is of iets dergelijks, maar wel dat het doorschuiven van bedrijven en grond naar jongere generaties niet optimaal verloopt.

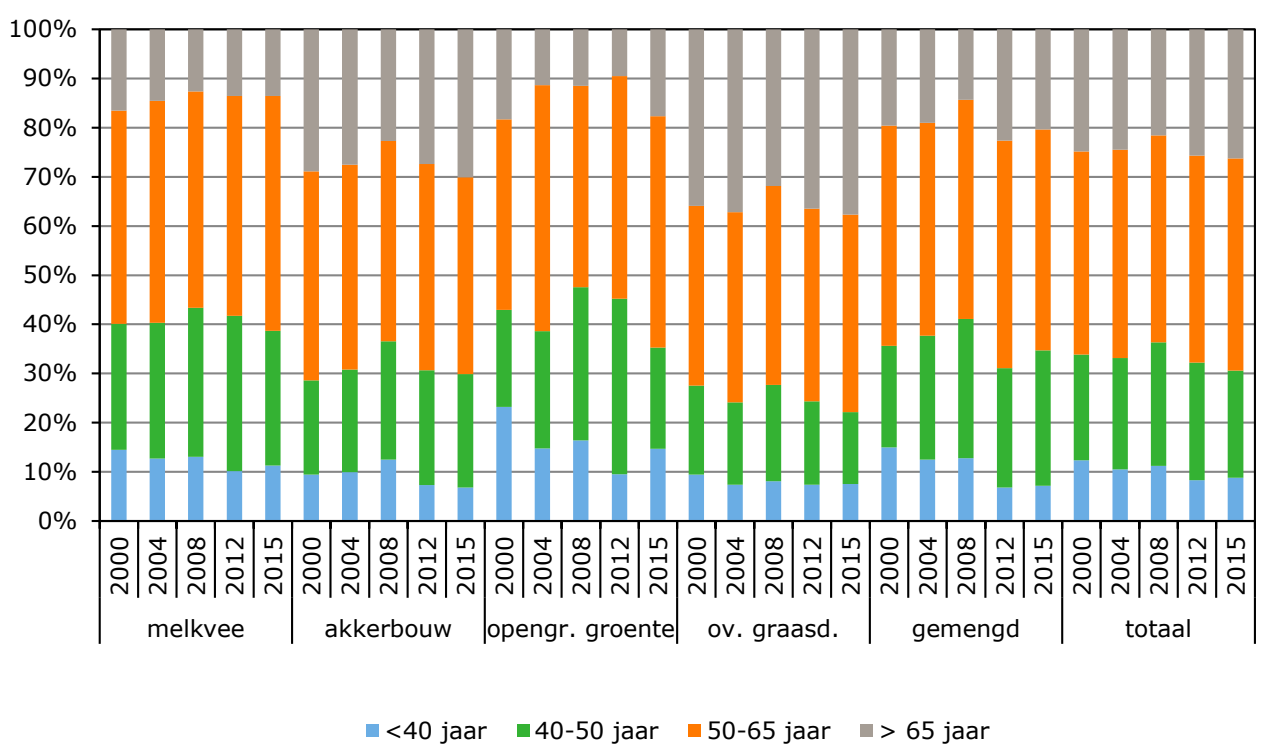

Figuur 2.3 Verdeling van de grondgebonden bedrijven naar bedrijfstype en leeftijd in 2000, 2004, 2008, 2012 en 2015

Bron: CBS Landbouwtelling, diverse jaren.

\section{Opvolgingssituatie op opengrondsgroente- en graasdierbedrijven zorgelijk}

De eerder geconstateerde vergrijzing in alle grondgebonden sectoren in Zuid-Holland hoeft voor de sectoren als totaal geen probleem te zijn als er maar voldoende opvolgers zijn. De opvolgingssituatie op met name de opengrondsgroente- en graasdierbedrijven in Zuid-Holland is wel zorgelijk.

In de landbouwtelling van het CBS wordt iedere vier jaar onderzocht welk deel van de ondernemers ouder dan 50 jaar een opvolger heeft. ${ }^{3}$ De resultaten voor Zuid-Holland bij de laatste vier meetmomenten, 2000, 2004, 2008 en 2012, worden getoond in Figuur 2.4. Deze figuur lijkt op Figuur 2.3 in die zin dat de twee onderste categorieën, jonger dan 40 jaar en '40-50 jaar' gelijk zijn aan de weergave in Figuur 2.3, maar de categorieën '50-65 jaar' en 'ouder dan 65 jaar' zijn nu vervangen door 'ouder dan 50 jaar' met of zonder opvolger.

\footnotetext{
2 Voor een deel gaat het bij dit bedrijfstype om ex-melkveehouders die bij het ouder worden hun melkkoeien vervangen door jongvee-opfok, schapenteelt of vleesvee/zoogkoeien.

3 Ondernemers jonger dan 50 jaar kunnen ook een opvolger hebben, maar vooral bij jonge kinderen en tieners is hun toekomstvisie lang niet altijd al duidelijk.
} 


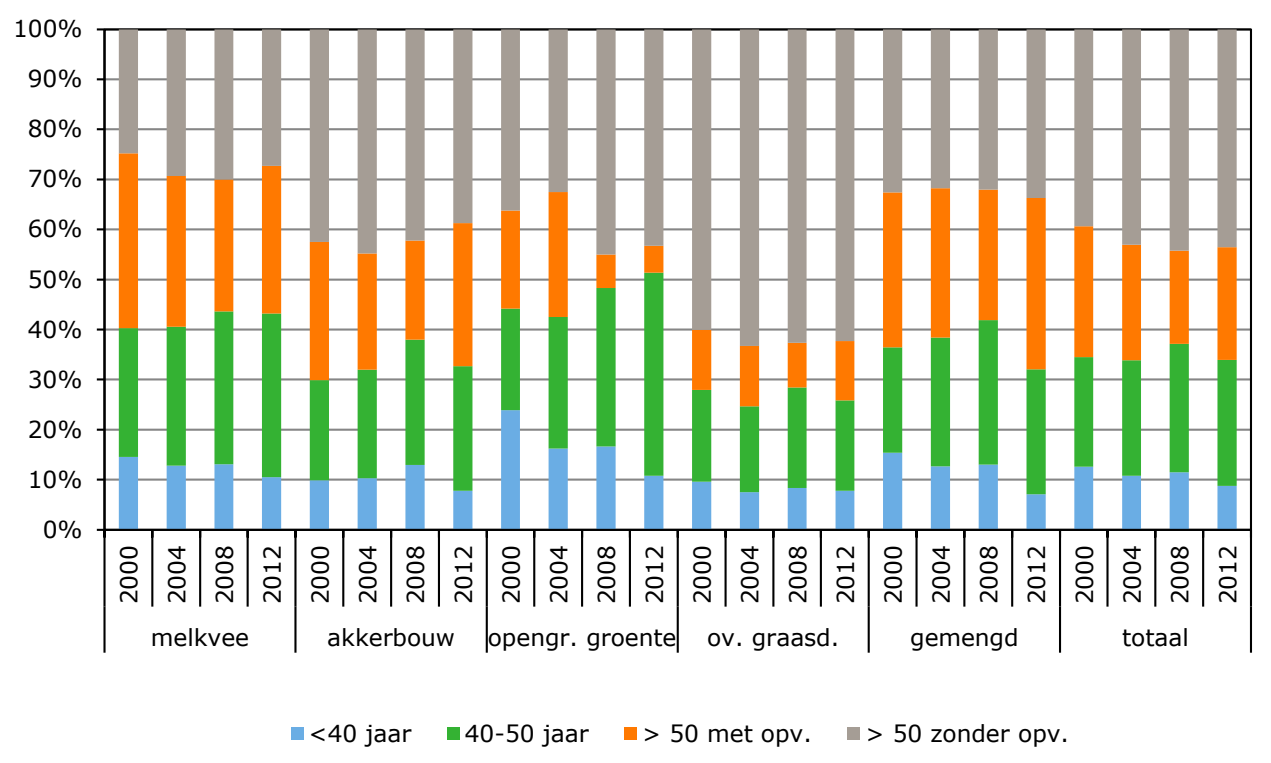

Figuur 2.4 Leeftijd en opvolgingssituatie in Zuid-Holland naar bedrijfstype in 2000, 2004, 2008 en 2012

Bron: CBS-Landbouwtelling, diverse jaren.

Gemiddeld had in 2012 20\% van de ondernemers in de grondgebonden sectoren in Zuid-Holland ouder dan 50 jaar een opvolger. De verschillen tussen de sectoren zijn evenwel groot op dit gebied. Op de opengrondsgroente- en overige graasdierbedrijven lagen de aandelen onder of net boven $10 \%$. Op de melkvee-, gemengde en akkerbouwbedrijven lag het percentage in dat jaar rond de $30 \%$. Een laag percentage opvolgers in combinatie met een laag percentage ondernemers jonger dan 50 jaar kan op termijn betekenen dat er grond uit met name de graasdierhouderij vrijkomt, waarmee andere bedrijven uit dezelfde of uit andere sectoren de noodzakelijke schaalvergroting kunnen realiseren. De opvolgingssituatie op met name de opengrondsgroente- en graasdierbedrijven is dus zorgelijk, maar dat biedt kansen voor bedrijven die willen of moeten groeien in omvang om rendabel te blijven of te worden.

\section{Opvolgingssituatie biologische sector gemiddeld vergelijkbaar met gangbaar}

In deze paragraaf krijgt de leeftijdsopbouw en opvolgingssituatie in de biologische sector specifiek aandacht. Deze sector kenmerkt zich door een ecologische of biologisch-dynamische (BD) werkwijze. Samen worden die 'biologisch' genoemd. Daarbij gebruikt men bij de teelt van gewassen geen kunstmest en chemische gewasbeschermingsmiddelen en in de dierhouderij (vrijwel) geen medicijnen. De organisaties SKAL en Demeter certificeren de ecologische en de BD-bedrijven en controleren of zij zich aan de regels houden. De biologische sector werkt wezenlijk anders dan de 'gangbare' sector en heeft onder andere als doel het milieu minder te belasten en het dierenwelzijn te versterken.

Figuur 2.5 heeft dezelfde opbouw als Figuur 2.4, maar heeft dus alleen betrekking op biologische ondernemers; Figuur 2.4 had betrekking op alle ondernemers, dus zowel gangbare als biologische ondernemers. Omdat er veel minder biologische dan gangbare boeren zijn, kon voor bepaalde sectoren of jaren geen diagram gemaakt worden; de aantallen voor dat segment waren te klein. De opvolgings-situatie was in de biologische melkveehouderij slechter dan in de gangbare melkveehouderij, maar voor de biologische akkerbouw beter. 


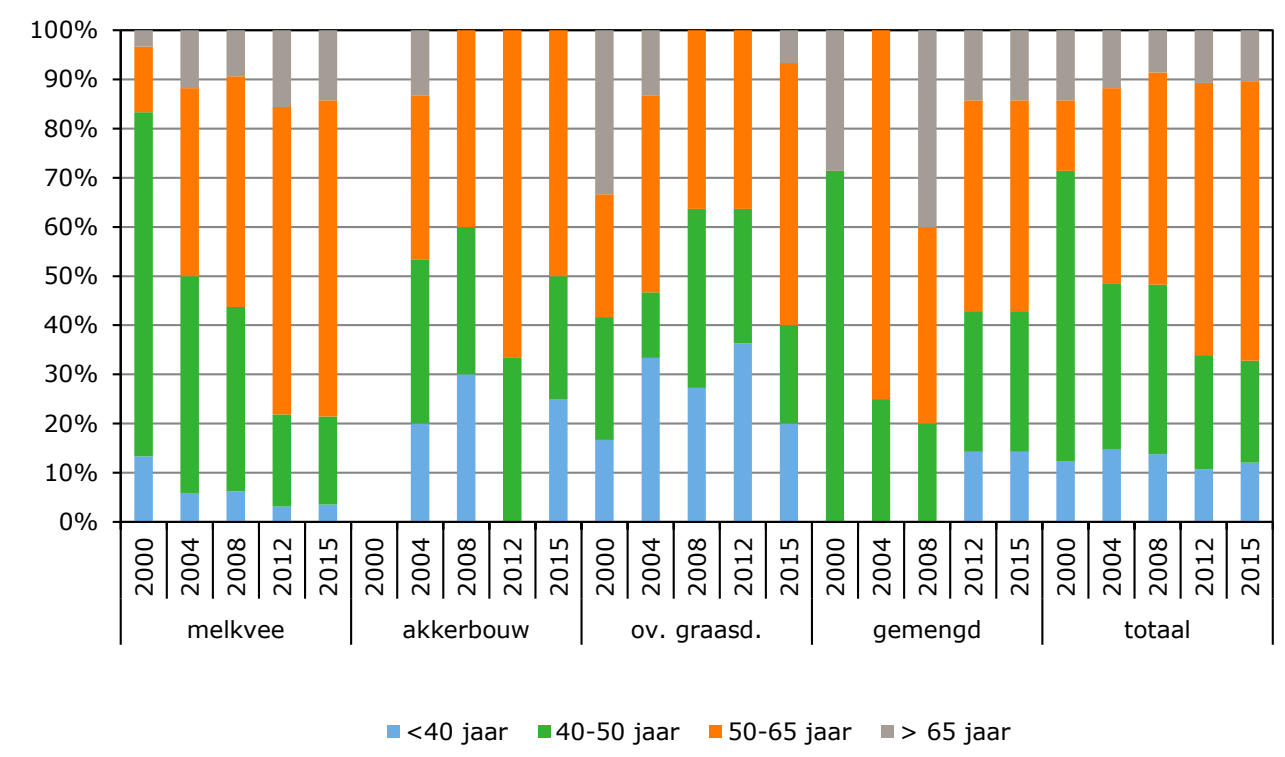

Figuur 2.5 Verdeling van de biologische grondgebonden bedrijven naar bedrijfstype en leeftijd in Zuid-Holland in 2000, 2004, 2008, 2012 en 2015. Voor akkerbouw waren er in 2000 te weinig waarnemingen

Bron: CBS-Landbouwtelling, diverse jaren.

Deze figuur voor alleen de biologische bedrijven in Zuid-Holland levert voor alle grondgebonden bedrijfstypen hetzelfde beeld op als voor de gangbare typen: 65\% van de ondernemers was in 2012 ouder dan 50 jaar en een kwart had een opvolger. In de biologische melkveehouderij was het aandeel bedrijven met opvolger kleiner dan in de gangbare melkveehouderij. Het aandeel $50^{+}$was in 2012 in de biologische melkveehouderij veel groter dan bij de gangbare collega's (bijna 80\% tegenover nog geen $60 \%$ ). Tegelijkertijd was het aandeel zonder opvolger binnen deze groep in dat jaar groter (50\% tegenover 30\%). Op de overige graasdierbedrijven was er in 2012 bij de gangbare bedrijven nog een klein aandeel met opvolger; op de biologische bedrijven ontbraken opvolgers echter volledig. Op de kleine groep van slechts 5 gemengde biologische bedrijven is het beeld qua $50^{+}$(minder, namelijk $50 \%$ ) en aandeel met opvolger (meer, namelijk $30 \%$ ) iets gunstiger. Bij de kleine groep van biologische akkerbouwbedrijven was het aandeel $50^{+}$redelijk vergelijkbaar en het aandeel met opvolger iets groter. Het aantal biologische akkerbouwbedrijven is sinds 2004 (toen nog 15) wel sterk gedaald en bedroeg in 2012 nog maar 6. De opvolgingssituatie was in de biologische melkveehouderij dus slechter dan in de gangbare melkveehouderij, maar voor de biologische akkerbouw beter. Gemiddeld was de opvolgingssituatie van de biologische sector vergelijkbaar met de gangbare sector.

\subsection{Bedrijfsomvang en inkomenspositie}

\section{Bedrijfsomvang en inkomenspositie in Zuid-Holland relatief gunstig}

Tabel 2.3 geeft informatie over de omvang en inkomenspositie van de twee belangrijkste grondgebonden sectoren in Zuid-Holland, de akkerbouw en de melkveehouderij. Daarbij zijn de gemiddelde parameters voor Zuid-Holland vergeleken met die van Nederland als geheel. Gemiddeld zijn de structuur en het inkomen op de akkerbouw- en melkveebedrijven in Zuid-Holland beter dan gemiddeld in Nederland. Uit de tabel blijkt dat zowel de akker- als de melkveebedrijven in ZuidHolland uitgedrukt in SO, aantal onbetaalde arbeidsjaareenheden (aantal meewerkende ondernemers en gezinsleden), areaal (ha) en netto toegevoegde waarde groter zijn dan gemiddeld in Nederland. Dat resulteert in hogere inkomens per bedrijf en per meewerkende ondernemer en gezinslid. Alleen is deze laatste lager op akkerbouwbedrijven in Zuid-Holland als gevolg van het grotere aantal onbetaalde arbeidskrachten c.q. meewerkende gezinsleden. Anders gezegd verdient men op ZuidHollandse akkerbouwbedrijven wel meer dan gemiddeld in Nederland, maar omgerekend naar alle 
meewerkende gezinsleden is het inkomen lager. De structuur en het inkomen op de akkerbouw- en melkveebedrijven in Zuid-Holland zijn dus beter dan gemiddeld in Nederland.

Tabel 2.3

Structuur en bedrijfsresultaat: 5-jaarlijkse gemiddelden (2010-2014) voor Zuid-Holland en Nederland voor akkerbouw- en melkveebedrijven

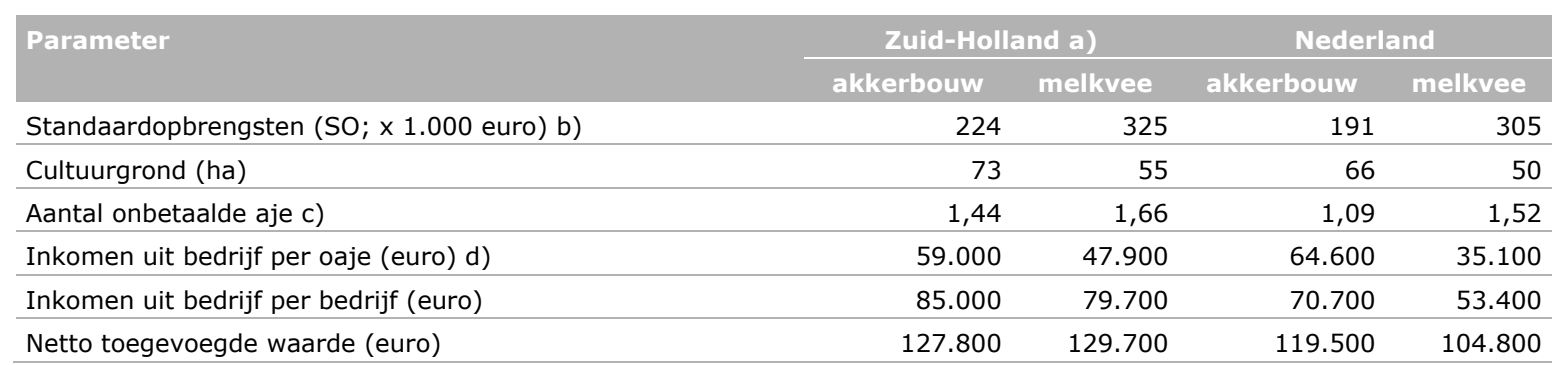

a) De akkerbouwbedrijven in Zuid-Holland bevinden zich met name op de Zuid-Hollandse eilanden. De akkerbouwbedrijven in de Noordwesthoek van Brabant zijn meegenomen om voldoende waarnemingen te genereren voor statistische betrouwbare uitkomsten;

b) Standaardopbrengst (SO) is een maat voor de economische bedrijfsomvang. In Bijlage 2 wordt over dit begrip een toelichting gegeven;

c) Aje = arbeidsjaareenheden, een maat voor de arbeidsinzet op het bedrijf;

d) Oaje = Onbetaalde arbeidsjaareenheden, een maat voor de arbeidsinzet van de ondernemer(s) en eventueel meewerkende gezinsleden op het bedrijf.

Bron: Bedrijveninformatienet van LEI Wageningen UR.

\section{Intensiteit van de grondgebonden landbouw}

De intensiteit van de landbouw zegt iets over de mate waarin de grond wordt gebruikt voor de teelt van gewassen of het houden van koeien of andere graasdieren. Over het algemeen gaat een hogere intensiteit samen met een hogere toegevoegde waarde en omzet per ha. Wereldwijd gezien is de landen tuinbouw in Nederland tamelijk intensief. Dat heeft onder andere te maken met de hoge prijzen van grond, arbeid en gebouwen in ons land, waardoor er een noodzaak is om hoge opbrengsten van hoogwaardige gewassen te realiseren. In Figuur B1.7 (in de bijlagen) is de intensiteit van het grondgebruik in de onderscheiden grondgebonden sectoren uitgedrukt in euro Standaardopbrengst per ha. Uit de figuur blijkt dat de opengrondsgroente- en gemengde bedrijven in Zuid-Holland minder intensief zijn dan gemiddeld in Nederland. De melkvee-, graasdier- en akkerbouwbedrijven zijn ongeveer even intensief. Het gaat hierbij in Zuid-Holland om SO's van 6.500, 2.600 en 3.200 euro per ha. De intensiteit van de rundveehouderij kan ook uitgedrukt worden in gve per ha (veedichtheid). Voor andere veehouderij-sectoren is dat niet mogelijk. Zuid-Holland is extensiever dan het landelijk gemiddelde, zoals blijkt uit Figuur B1.8. Bijna 90\% van de melkkoeien en het jongvee wordt gehouden op bedrijven met een intensiteit van minder dan $3 \mathrm{gve} / \mathrm{ha}$. Voor Nederland als geheel ligt dit percentage rond de $75 \%$.

\section{Beschouwing over de afschaffing van de melkquota}

De melkprijs staat momenteel (mei 2016) fors onder druk, maar ligt nog wel een paar eurocent boven het laagste niveau van 2009. De EU-interventieregeling voor melk en zuivelproducten is eind 2008 buiten werking getreden, waardoor (met name neerwaartse) schommelingen in melkprijzen niet meer gedempt worden. Naar verwachting zullen die schommelingen de komende jaren toenemen door het wegvallen van de melkquotering per 1 april 2015. Op Europees niveau is er per begin $20165 \%$ meer melk aangevoerd dan het jaar daarvoor. Wel is er een 'lichte' interventieregeling ingesteld als reactie op de Ruslandboycot in augustus 2014. Dit houdt in dat er openbare en particuliere opslagregelingen gelden. ${ }^{4}$

De Rabobank ziet in haar reactie op de huidige lage melkprijzen nog geen licht aan het eind van de tunnel wat betreft de melkprijzen en noemt hiervoor een aantal oorzaken, zoals de lage olieprijs van

4 http://ec.europa.eu/agriculture/milk-market-observatory/pdf/eu-stocks-butter-smp_en.pdf 
zuivelimporterende landen, de algemene slechte economische situatie, gunstige weersomstandigheden in Oceanië en een stijging van de melkproductie in het Midwesten van de Verenigde Staten. ${ }^{5}$

Naast effecten op de melkprijs heeft de afschaffing van het melkquotum ook effecten gehad op de mestproductie en op de vraag naar ruwvoer en grond. Dat betekent dat er ook voor de akkerbouwsector een grotere druk op de grondprijs is gekomen, dat er meer mest aangeboden wordt en vaker ruwvoedergewassen op akkerbouwbedrijven worden geteeld.

\section{Beschouwing over de relatie tussen bedrijfsomvang en inkomen}

In de melkveehouderij wordt er in een jaar met matige prijzen door de grote bedrijven naar verhouding minder verdiend dan op de kleinere bedrijven. Dit wordt duidelijk zichtbaar wanneer 2009 wordt vergeleken met 2014. In 2009 was de melkprijs $€ 27,5$ en in 2014 bijna $€ 42,5$ per $100 \mathrm{~kg}$. Tabel 2.4 laat zien welke inkomensverschillen dit oplevert naar bedrijfsomvang in so gemeten.

\section{Tabel 2.4}

Schaal- en inkomenseffecten uit bedrijf voor melkveebedrijven in relatie tot melkprijs

\begin{tabular}{|c|c|c|c|c|c|}
\hline \multirow[t]{2}{*}{ Inkomen in jaar: } & \multirow[b]{2}{*}{ alle } & \multicolumn{4}{|c|}{ Klassen in omvang (SO * 1.000 euro) } \\
\hline & & $<150$ & $150-250$ & 250-500 & $>500$ \\
\hline \multicolumn{6}{|l|}{2009} \\
\hline Inkomen uit bedrijf per onbetaalde aje & -2.000 & 0 & 1.600 & -7.900 & 7.600 \\
\hline Inkomen uit bedrijf & 65.200 & 23.700 & 35.300 & 63.300 & 152.800 \\
\hline Inkomen uit bedrijf per onbetaalde aje & 42.400 & 21.100 & 27.000 & 39.600 & 77.000 \\
\hline
\end{tabular}

Bron: Bedrijveninformatienet van LEI Wageningen UR, eigen bewerking.

Wat opvalt is dat het absolute verschil in inkomen per onbetaalde aje tussen de groep grootste en kleinste bedrijven in 20098.000 euro was. In 2014 was dit 56.000 euro. Het inkomen per eenheid melk was in 2009 voor de grootste bedrijven dan ook veel kleiner dan in 2014. Bij een nog lagere prijs keert zich dit tegen de omvang van de grotere bedrijven. Dan zou het inkomen zelfs lager kunnen uitpakken dan op de kleinere bedrijven doordat op elke liter melk geld toegelegd moet worden.

\subsection{Conclusies}

In dit hoofdstuk komt een relatief gunstig beeld naar voren over de structuur van de grondgebonden landbouw in de provincie Zuid-Holland, met name van de akkerbouw en melkveehouderij. In ZuidHolland bevindt zich $7 \%$ van het totaal aantal grondgebonden bedrijven in Nederland. Daarbij gaat het vooral om melkveebedrijven (ruim 1.200), overige graasdierbedrijven (eveneens ruim 1.200) en akkerbouwbedrijven (ruim 700). In Zuid-Holland zijn dus de melkveehouderij, de overige graasdierbedrijven en de akkerbouwbedrijven qua aantallen bedrijven de grootste grondgebonden sectoren. Wel vertoont de totale werkgelegenheid op de grondgebonden bedrijven in Zuid-Holland sinds 2003 een dalende trend. De meeste werkgelegenheid bevindt zich op de melkveehouderijbedrijven in ZuidHolland, maar op die bedrijven is de werkgelegenheid sinds 2003 in absolute termen ook het sterkst gedaald. Opvallend is dat op de overige graasdierbedrijven de werkgelegenheid sinds 2003 is toegenomen, namelijk met meer dan 20\%. Dit komt met name door de verschuiving van melkvee naar overige graasdieren.

$\overline{5 \text { www.rabobank.nl/bedrijven/cijfers-en-trends/veehouderij/kwartaalbericht-zuivel-april-2016 }}$ 
Grasland beslaat met 68.000 ha het grootste areaal in Zuid-Holland, wat mede verklaarbaar is door de relatief grote omvang van de veenweidegebieden in het Zuid-Hollandse deel van het Groene Hart. Daarbij aansluitend wordt in de provincie ongeveer 12.000 ha groenvoedergewassen geteeld, met name snijmais. Bij de akkerbouwgewassen vallen met name de granen met ruim 15.000 ha en de aardappelen met 10.000 ha op. Deze gewassen worden met name geteeld op de Zuid-Hollandse eilanden en in de droogmakerijen. De opengrondsgroentesector heeft met 12.500 ha ook een significant aandeel van de grond in gebruik.

Op de grondgebonden bedrijven in Zuid-Holland treedt in alle sectoren vergrijzing op. Opvallend is dat bij alle grondgebonden bedrijfstypen in de provincie in 201560 tot soms $80 \%$ van de ondernemers 50 jaar of ouder is. In de akkerbouw en op de overige graasdierbedrijven is een significant aandeel van de ondernemers zelfs $65^{+}$.

Gemiddeld had in 2012 20\% van de ondernemers in de grondgebonden sectoren in Zuid-Holland ouder dan 50 jaar een opvolger. De verschillen tussen de sectoren zijn evenwel groot op dit gebied. Op de opengrondsgroente- en overige graasdierbedrijven lagen de aandelen onder of net boven $10 \%$. Op de melkvee-, gemengde en akkerbouwbedrijven lag het percentage in dat jaar rond de $30 \%$.

Gemiddeld zijn de structuur en het inkomen op de akkerbouw- en melkveebedrijven in Zuid-Holland beter dan gemiddeld in Nederland. Zowel de akker- als de melkveebedrijven in Zuid-Holland zijn gemiddeld groter zijn dan in Nederland als geheel. Dat resulteert in relatief hogere inkomens per bedrijf en per meewerkende ondernemer en meewerkend gezinslid. 


\section{Het agrocluster in Zuid-Holland}

\subsection{Inleiding}

In dit hoofdstuk gaan we in op de bijdrage van het grondgebonden agrocluster in Zuid-Holland aan de totale werkgelegenheid en de toegevoegde waarde in deze provincie. De primaire land- en tuinbouwsectoren zijn zowel aan de inputkant (veevoer, kunstmest) als aan de outputkant (verwerkende industrie) nauw verweven met andere sectoren in de economie. Het agrocluster is in deze studie gedefinieerd als het totaal van land- en tuinbouwbedrijven, visserij, voedings- en genotmiddelenindustrie en de aan deze sectoren toeleverende bedrijven. De werkgelegenheid en toegevoegde waarde van alle betrokken toeleverende bedrijven worden niet volledig meegenomen. Alleen het deel van hun omzet dat gegenereerd wordt uit toelevering aan de primaire sectoren en de verwerkende industrie wordt meegerekend in het agrocluster. In Bijlage 3 van dit rapport wordt verder ingegaan op de achtergronden van dit hoofdstuk, zoals gebruikte informatie en methodiek. Ook wordt nader ingegaan op definities en afbakening. In paragraaf 3.2 wordt eerst de betekenis van het agrocluster in Zuid-Holland beschreven. Ten slotte worden in de laatste paragraaf een aantal conclusies getrokken.

\subsection{Betekenis van het agrocluster}

Het agrocluster in een gebied in de definitie van het LEI bestaat uit drie hoofdsectoren: land- en tuinbouw, visserij en voedings- en genotmiddelenindustrie (zie Bijlage 3). Ook de toeleverende bedrijven worden, voor het deel dat ze toeleveren aan de drie hoofdsectoren, tot het agrocluster gerekend. Volgens de Landbouwtelling van het CBS waren er in Zuid-Holland in 2013 ruim 30.000 arbeidskrachten (in arbeidsjaareenheden, aje) werkzaam in de land- en tuinbouw. Hiervan is het grootste deel (55\%) werkzaam in de glastuinbouw, gevolgd door $26 \%$ in de opengrondstuinbouw. Het aandeel van de intensieve veehouderij is met $1 \%$ het laagst. Zuid-Holland heeft een aandeel van $19 \%$ in het totale aantal arbeidskrachten werkzaam in de land- en tuinbouw in Nederland en behoort daarmee samen met Noord-Brabant tot de grootste provincies voor wat betreft het aantal personen die in de land- en tuinbouw werkzaam zijn.

De voedings- en genotmiddelenindustrie is nauw verweven is met de primaire productiesectoren (landbouw, tuinbouw en visserij). Echter, omdat de glastuinbouw, de grootste sector in Zuid-Holland wat betreft werkgelegenheid in de land- en tuinbouw, nauwelijks verbonden is met een verwerkende industrie zien we deze nauwe verwevenheid niet direct terugkomen in de cijfers in Tabel 3.1, waarin het aantal werkzame personen in de voedings- en genotmiddelenindustrie in Zuid-Holland in 2013 weergegeven is.

Los van de nauwe verwevenheid met de primaire sectoren kan de voedings- en genotmiddelenindustrie in een bepaalde provincie ook groot zijn door een strategische ligging (haven, vliegveld, rivier). Dit speelt vooral bij de verwerking van buitenlandse agrarische grondstoffen zoals oliehoudende zaden, koffie, thee, cacao en veevoedergrondstoffen. In Tabel 3.1 wordt dit belang onderschreven met het aandeel (56\%) van Zuid-Holland in de totale werkgelegenheid van de margarine-, vetten- en oliënindustrie in Nederland. Daarnaast is ook het aandeel van Zuid-Holland in vervaardiging van overige voedingsmiddelen hoog. Het grote aandeel van de drankenindustrie in ZuidHolland is nagenoeg volledig toe te schrijven aan de aanwezigheid van Heineken in deze provincie. 
Tabel 3.1

Aantal werkzame personen in de voedings- en genotmiddelenindustrie in Zuid-Holland en Nederland, 2013

\begin{tabular}{|c|c|c|c|}
\hline Cluster & Zuid-Holland & Nederland & $\begin{array}{c}\text { Aandeel van } \\
\text { Zuid-Holland } \\
\text { in Nederland } \\
(\%)\end{array}$ \\
\hline Slachterijen en vleesverwerkende industrie & 2.020 & 18.685 & $10,8 \%$ \\
\hline Visverwerkende industrie & 321 & 3.819 & $8,4 \%$ \\
\hline Aardappelverwerking & 324 & 4.064 & 8,0 \\
\hline Groenten- en fruitverwerkende industrie & 364 & 5.890 & 6,2 \\
\hline Margarine-, vetten- en oliën industrie & 1.591 & 2.826 & 56,3 \\
\hline Meel- en zetmeelindustrie & 373 & 2.697 & 13,8 \\
\hline Brood- en banketbakkerijen en deegwarenindustrie & 4.596 & 32.647 & 14,1 \\
\hline Overige voedingsmiddelenindustrie & 3.444 & 11.485 & 30,0 \\
\hline Drankenindustrie & 2.950 & 8.249 & 35,8 \\
\hline Totaal voedings- en genotmiddelenindustrie & 18.007 & 122.568 & 14,7 \\
\hline
\end{tabular}

Bron: LISA 2013, na bewerking met Agrarische input-outputtabel.

Uit Tabel 3.1 blijkt dat de totale werkgelegenheid in de voedings- en genotmiddelenindustrie in Zuid-Holland bijna $15 \%$ van die in deze sector in heel Nederland bedraagt. Dit is zo'n $4 \%$ lager dan het aandeel van Zuid-Holland in de nationale werkgelegenheid in de primaire land- en tuinbouw en de visserij.

De totale toegevoegde waarde van alle economische activiteiten in Zuid-Holland samen bedroeg volgens het CBS in 2013 ruim 124 miljard euro. Dit komt neer op iets meer dan $21 \%$ van de totale nationale toegevoegde waarde. Zuid-Holland is daarmee de grootste provincie van ons land qua economische activiteiten. Ook het totale arbeidsvolume van Zuid-Holland komt, met bijna anderhalf miljoen arbeidsjaren, uit op iets meer dan $21 \%$ van het Nederlandse totaal en heeft daarmee in 2013 de grootste werkgelegenheid van alle provincies.

Het totale agrocluster in Zuid-Holland genereerde in 2013 circa 7,5 miljard euro toegevoegde waarde en bijna 90.000 arbeidsjaren werkgelegenheid. Het aandeel van het totale agrocluster, dus inclusief de op buitenlandse agrarische grondstoffen gebaseerde voedings- en genotmiddelenindustrie en de toeleverende bedrijven aan de agribusiness, in de totale economie van Zuid-Holland ligt voor zowel toegevoegde waarde als de werkgelegenheid rond de $6 \%$ (zie Tabel 3.2). Vergeleken met het vergelijkbare cijfer voor Nederland $(8 \%)$ is dit percentage voor Zuid-Holland relatief laag te noemen. Dit hangt onder andere samen met de mate van industrialisatie in Zuid-Holland en het aantal personen dat in overheidsdienst is, onder andere op de diverse ministeries.

De primaire land- en tuinbouwbedrijven, de op binnenlandse grondstoffen gebaseerde verwerkende industrie en de daarmee samenhangende toelevering en distributie dragen samen voor ongeveer $75 \%$ bij aan de werkgelegenheid en de toegevoegde waarde van het agrocluster in Zuid-Holland. De op buitenlandse agrarische grondstoffen gebaseerde verwerkende industrie draagt nog eens zo'n $25 \%$ bij. Binnen die $92 \%$ zijn het vooral de primaire productie en de toelevering met respectievelijk $40 \%$ en $25 \%$ die het meeste bijdragen. 
Tabel 3.2

Kerncijfers van het totale agrocluster in Zuid-Holland, 2013

\begin{tabular}{|c|c|c|}
\hline Cluster & $\begin{array}{c}\text { Toegevoegde waarde } \\
\text { (m/n. euro) }\end{array}$ & $\begin{array}{c}\text { Werkgelegenheid } \\
\text { (arbeidsjaren) }\end{array}$ \\
\hline Agrocluster, totaal & $7.481,1$ & $87.189,8$ \\
\hline Primaire productie & $3.028,7$ & $35.798,8$ \\
\hline Verwerking & 406,9 & $5.631,8$ \\
\hline Distributie & 361,9 & $4.633,6$ \\
\hline
\end{tabular}

Bron: LEI, Agrarische input-outputtabel 2013.

\section{Akkerbouwcluster}

Het akkerbouwcluster draagt in Zuid-Holland met 31,5\% en bijna 27,5\% relatief minder bij aan respectievelijk de toegevoegde waarde en de werkgelegenheid van het totale agrocluster dan gemiddeld voor heel Nederland (zie Tabel 3.3). Het akkerbouwcluster is, wat betreft toegevoegde waarde, in Zuid-Holland wel het tweede agrocluster in belangrijkheid. Het totale akkerbouwcluster (inclusief de verwerking van buitenlandse grondstoffen) was in Zuid-Holland in 2013 goed voor ruim 2,3 miljard euro toegevoegde waarde en bijna 24.000 arbeidsjaren werkgelegenheid. Hiervan hangt $18 \%$ samen met de productie en verwerking van binnenlandse akkerbouwproducten. Door de aanwezigheid van de Rotterdamse haven worden er in Zuid-Holland relatief veel buitenlandse agrarische grondstoffen verwerkt in bijvoorbeeld de oliën- en vettenindustrie, de meelindustrie en de veevoederindustrie.

\section{Grondgebonden veehouderijcluster}

Het grondgebonden veehouderijcluster (melkveehouderij en overige graasdieren) realiseerde in Zuid-Holland in 2013 bijna 900 miljoen euro toegevoegde waarde en meer dan 12.000 arbeidsjaren werkgelegenheid. De bijdrage van dit cluster aan de toegevoegde waarde van het totale agrocluster in Zuid-Holland is met ruim $11 \%$ relatief bescheiden. Dit heeft te maken met het relatief geringe aantal melkkoeien in de provincie (ongeveer $6 \%$ van het landelijk totaal) en het relatief lage aantal zuivelverwerkende bedrijven en slachterijen (zie Tabel 3.1). Op de primaire melkveebedrijven zelf wordt $12 \%$ van de toegevoegde waarde en $22 \%$ van de werkgelegenheid van dit cluster gerealiseerd. Wat betreft grondgebruik is het veehouderijcluster met ruim $60 \%$ wel het belangrijkste agrocluster in ZuidHolland. Landelijk gezien draagt het grondgebonden veehouderijcluster circa $20 \%$ bij aan de totale toegevoegde waarde van het nationale agrocluster.

\section{Opengrondstuinbouwcluster}

Het opengrondstuinbouwcluster omvat in dit rapport de teelt en verwerking van opengrondsgroenten, fruit, bloembollen en boomkwekerijproducten, evenals de aan deze sectoren toeleverende bedrijven. Hoewel dit agrocluster in de primaire land- en tuinbouwbedrijven veel werkgelegenheid biedt, is het belang van dit agrocluster in de werkgelegenheid van het totale agrocluster in Zuid-Holland beperkt. Dit hangt samen met het feit dat dit cluster nauwelijks verwerkende industrie heeft. Het totale opengronds-tuinbouwcluster (inclusief de verwerking van buitenlandse groenten en fruit) is in Zuid-Holland goed voor meer dan $305 \mathrm{mln}$. euro toegevoegde waarde en ruim 5.100 arbeidsjaren werkgelegenheid. Hiervan hangt bijna $90 \%$ samen met de productie en verwerking van in het binnenland geproduceerde agrarische producten en is ongeveer $50 \%$ respectievelijk $60 \%$ gerealiseerd op de primaire land- en tuinbouwbedrijven. 
Tabel 3.3

Aandeel van afzonderlijke deelclusters in het totale agrocluster, 2013

\begin{tabular}{|c|c|c|c|c|}
\hline Cluster & \multicolumn{2}{|c|}{ Toegevoegde waarde ( $\%)$} & \multicolumn{2}{|c|}{ Werkgelegenheid (\%) } \\
\hline Akkerbouw & 31,5 & 45,8 & 27,4 & 37,5 \\
\hline Glastuinbouw & 48,2 & 15,4 & 46,3 & 14,5 \\
\hline Grondgebonden veehouderij & 11,6 & 19,9 & 14,5 & 23,5 \\
\hline Visserij & 1,4 & 1,7 & 1,3 & 1,6 \\
\hline
\end{tabular}

Bron: LEI, Agrarische input-outputtabel 2013.

\section{Glastuinbouwcluster}

Het glastuinbouwcluster draagt in Zuid-Holland met respectievelijk $48 \%$ en $46 \%$ beduidend meer bij aan de toegevoegde waarde en werkgelegenheid van het totale agrocluster dan gemiddeld in Nederland (15\%). Het totale glastuinbouwcluster (inclusief de verwerking van buitenlandse groenten) is hiermee dan ook veruit het belangrijkste cluster in Zuid-Holland en is goed voor bijna 3,6 miljard euro toegevoegde waarde en circa 40.000 arbeidsjaren werkgelegenheid. Hiervan is ongeveer $72 \%$ respectievelijk $71 \%$ direct afkomstig van de primaire land- en tuinbouwbedrijven. Net als bij het opengrondstuinbouwcluster draagt de verwerkende industrie zeer gering bij aan het totale resultaat.

\section{Intensieve veehouderijcluster}

Het intensieve veehouderijcluster omvat het houden van dieren (kalveren, pluimvee, varkens) op intensieve wijze in stallen. Met uitzondering van varkens ( $1 \%$ van het nationaal totaal) komt intensieve veehouderij in Zuid-Holland nauwelijks voor. De bijdrage van het intensieve veehouderijcluster aan de toegevoegde waarde en de werkgelegenheid van het totale agrocluster in Zuid-Holland is daardoor met ongeveer $4 \%$ dan ook zeer gering.

\section{Visserijcluster}

Het visserijcluster draagt in Zuid-Holland met ruim 100 miljoen euro toegevoegde waarde en ruim 1.100 arbeidsjaren werkgelegenheid relatief in zeer geringe mate bij aan het totale agrocluster in Zuid-Holland.

\subsection{Conclusies}

De totale toegevoegde waarde van alle economische activiteiten in Zuid-Holland samen bedroeg volgens het CBS in 2013 ruim 124 miljard euro. Dit komt neer op iets meer dan 21\% van de totale nationale toegevoegde waarde. Zuid-Holland is daarmee, wat betreft toegevoegde waarde, de grootste provincie van Nederland. Ook het totale arbeidsvolume van Zuid-Holland komt, met bijna 1,5 miljoen arbeidsjaren, uit op meer dan 21\% van het Nederlandse totaal en is daarmee in 2013 de hoogste van alle provincies.

Het aandeel van het totale agrocluster, dus inclusief de voedings- en genotmiddelenindustrie die is gebaseerd op buitenlandse grondstoffen, in de totale economie van Zuid-Holland ligt voor zowel toegevoegde waarde als werkgelegenheid rond de $6 \%$. Vergeleken met het cijfer voor Nederland (8\%) is dit voor Zuid-Holland laag.

De bijdrage van de diverse schakels (primair, verwerking, toelevering en distributie) binnen het totale agrocluster in Zuid-Holland verschilt sterk van deelcluster tot deelcluster (Figuur 3.1). In het akkerbouw-cluster wordt relatief veel toegevoegde waarde gecreëerd in de industrieën die toeleveren aan de verwerkende industrie. Dit hangt sterk samen met het grote belang van de verwerkende industrie in dit cluster. 
Het akkerbouwcluster draagt in Zuid-Holland met 31,5\% en bijna 27,5\% bij aan respectievelijk de toegevoegde waarde en de werkgelegenheid van het totale agrocluster in Zuid-Holland. Het akkerbouwcluster is, wat betreft toegevoegde waarde, in Zuid-Holland het tweede agrocluster in belangrijkheid. Het totale akkerbouwcluster (inclusief de verwerking van buitenlandse grondstoffen) was in Zuid-Holland in 2013 goed voor ruim 2,3 miljard euro toegevoegde waarde en bijna 24.000 arbeidsjaren werkgelegenheid. Hiervan hangt $18 \%$ samen met de productie en verwerking van binnenlandse akkerbouwproducten.

De bijdrage van het grondgebonden veehouderijcluster aan de toegevoegde waarde van het totale agrocluster in Zuid-Holland is met ruim $11 \%$ relatief bescheiden te noemen. Op de primaire melkveebedrijven zelf wordt $12 \%$ van de toegevoegde waarde en $22 \%$ van de werkgelegenheid van dit cluster gerealiseerd. Wat betreft grondgebruik is het veehouderijcluster met ruim $60 \%$ wel het belangrijkste agrocluster in Zuid-Holland.

Het voorgaande is samengevat in Figuur 3.1.

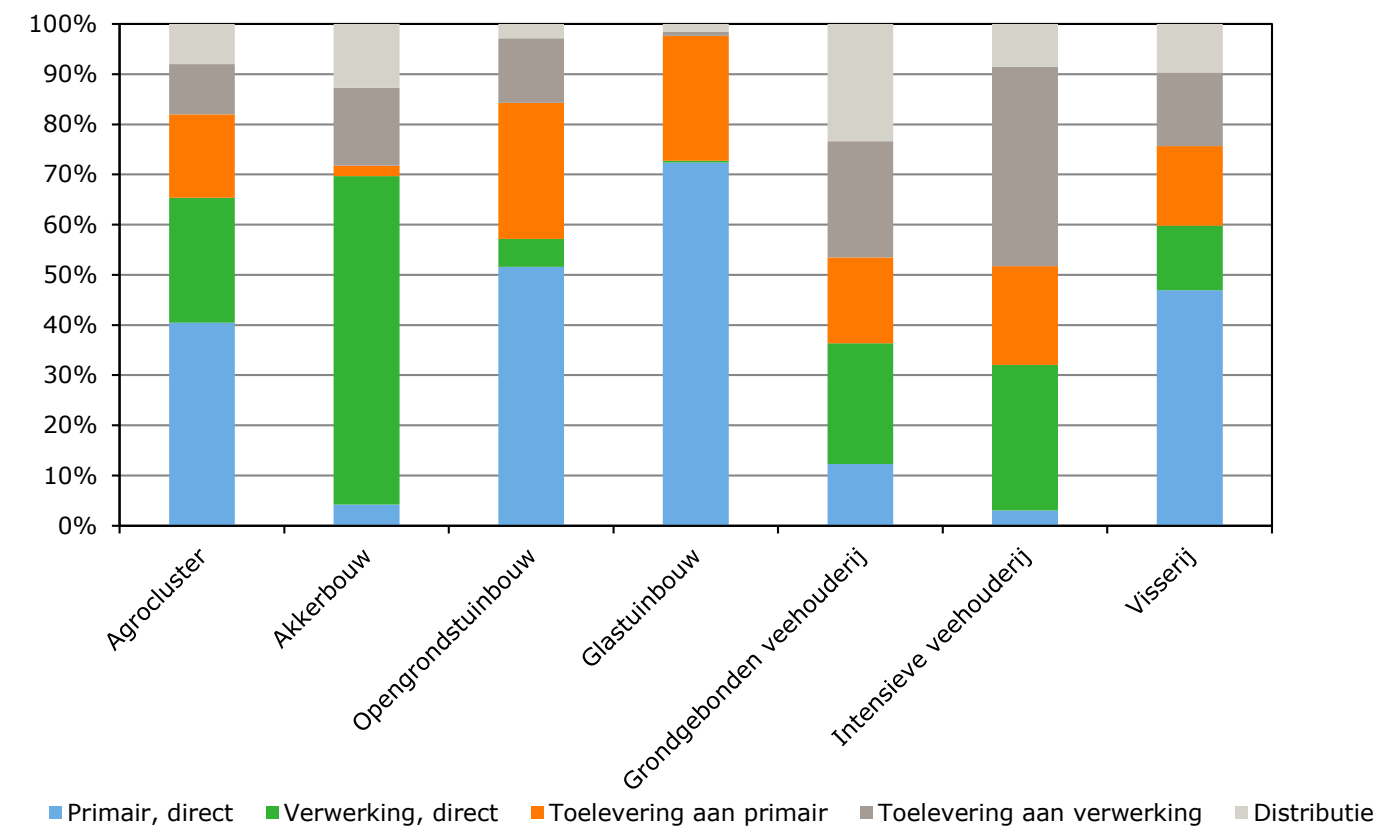

Figuur 3.1 Relatieve bijdrage van diverse schakels aan de toegevoegde waarde van de verschillende clusters in Zuid-Holland (\%), 2013 


\section{Innovatie}

\subsection{Inleiding}

Innovatie op allerlei niveaus is een belangrijke voorwaarde om de Nederlandse land- en tuinbouw onderscheidend en concurrerend te houden. Agrarische ondernemers nemen hiertoe dikwijls zelf het initiatief maar werken daarbij wel vaak samen met collega's, het 'grote' bedrijfsleven, kennisinstellingen en overheden. In de provincie Zuid-Holland is momenteel veel aandacht voor innovatie als drijvende kracht voor de toekomst van de land- en tuinbouw in de regio, zeker voor de grondgebonden sectoren. In dit hoofdstuk gaan we daar nader op in. Eerst geven we een korte beschouwing over innovatie in de land- en tuinbouw in het algemeen en vervolgens zoomen we in op de grondgebonden landbouw in de provincie Zuid-Holland. Vervolgens signaleren we een aantal trends en ontwikkelingen op dit vlak, om ten slotte te komen tot een aantal mogelijkheden om innovatie in de grondgebonden landbouw in de provincie verder te versterken.

\subsection{Innovatie in de Nederlandse land- en tuinbouw}

Innovatie is één van de speerpunten van het huidige Nederlandse kabinet, maar ook van de Europese Commissie. Nederland is een belangrijke voedselproducent en -exporteur in Europa en in de wereld; een positie die mede is te danken aan voortdurende innovaties in de hele agrokolom. Hierbij kan het gaan om 'echte' innovaties, waarbij er een eerste introductie of ingebruikname is, om (technische) vernieuwingen die door de bedrijven zelf als een aanzienlijke verbetering van de bedrijfsvoering worden gezien of om producten die voor het bedrijf nieuw zijn. Bij productinnovaties gaat het om de introductie van nieuwe producten, zoals nieuwe soorten bloemen en planten, nieuwe smaaktomaten of streek-producten. Een nieuwe plantmachine of een innovatieve voerschuifrobot zijn voorbeelden van proces-innovaties. Soms gaan product- en procesinnovaties samen, bijvoorbeeld als een pluimveehouder een sterker kuiken gebruikt dat beter groeit, of als een nieuwe kleinbladige komkommerplant wordt gebruikt. Kostenbesparing en verbetering van de productkwaliteit gaan zo soms hand in hand. Naast product- en procesinnovaties zijn er ook vernieuwingen in de keten, zoals nieuwe businessmodellen voor bijvoorbeeld korte ketens of voor financiering (zie onder andere Van der Schans et al., 2015). We kennen ook sociale innovaties, waarbij vernieuwingen in het maatschappelijke en overheidsdomein aan de orde zijn (bijvoorbeeld vernieuwingen in de gezondheidszorg, zoals zorglandbouw).

In de meeste gevallen zijn het de agrarische ondernemers zelf die het initiatief nemen tot (een) innovatie. Bij productinnovaties spelen ook toeleveranciers en collega-ondernemers een belangrijke rol als mede-initiatiefnemer. Nieuwe producten worden veelal door boeren en tuinders zelf ontwikkeld. Bij de procesinnovaties is dat minder het geval. In sommige gevallen worden door boeren en tuinders aparte ondernemingen opgericht om innovaties te ontwikkelen, vooral met het oog op risicospreiding.

De meeste innovaties worden ingevoerd om meerdere redenen. Verlaging van de kostprijs in het algemeen blijft een belangrijk doel. In veel gevallen speelt vervanging of uitbreiding van productiemiddelen een belangrijke rol, waarmee duidelijk wordt dat ondernemers innovatie en vernieuwing vaak als een integraal onderdeel zien van de investeringscyclus en de bedrijfsgroei. Arbeidsbesparing en verbetering van de arbeidsomstandigheden zijn belangrijke redenen om de productieprocessen te vernieuwen, evenals verlaging van het energiegebruik (kostenbesparing in met name de glastuinbouw) en verbetering van de milieuprestaties. Relatief veel vernieuwingen in de veehouderij hebben momenteel te maken met dierenwelzijn en diergezondheid.

In de agrarische sector komen relatief meer procesinnovaties dan productinnovaties voor. Hoewel procesinnovaties zeker belangrijk zijn - ook voor verbetering van de milieuprestaties, het dierenwelzijn 
en de arbeidsomstandigheden - zal het voor primaire bedrijven in de toekomst steeds belangrijker worden om daadwerkelijk toegevoegde waarde voor afnemers en consumenten te leveren. Producten marketinginnovaties spelen daarbij een grote rol. Op kostprijs concurreren is en blijft een hard gevecht, en klantenbinding door kwaliteit, niches, service en samenwerking is een manier om de concurrentiekracht duurzaam te verbeteren. Natuurlijk zijn hiervoor de mogelijkheden in de ene sector groter dan in de andere, maar de afgelopen jaren is er wel in alle sectoren een beweging zichtbaar naar product-innovaties. Via streekproducten, tussensegmenten, merken en duurzame ketenrelaties gebaseerd op snelheid en service proberen ondernemers een niche voor zichzelf te creëren (zie onder andere Van der Meer et al., 2015).

Innovatie is van strategisch belang voor agrarische bedrijven en bedrijven in de keten. Innovatie is echter ook een belangrijke voorwaarde voor een goede voedselvoorziening binnen veranderende maatschappelijke randvoorwaarden. De agrosector in Nederland kan worden geduid als een kennisintensieve sector. Kennis is een belangrijke drijvende kracht achter de innovatie in de Nederlandse agrosector. Bedrijfsleven, overheid en de kennisinstellingen zijn daarom van oudsher sterk met elkaar verbonden. Het vroegere OVO-drieluik, waarbij (publiek) onderzoek via voorlichting bij de primaire bedrijven en onderwijs werd verspreid, is echter grotendeels verdwenen en langzamerhand overgegaan in de 'gouden driehoek' van overheden, bedrijven en kennisinstellingen. Dit drieluik functioneert vanuit dezelfde doelstellingen, maar heeft een veel sterkere private inbreng in publiek-private samenwerkingen in de vorm van convenanten en innovatieprogramma's als Food \& Nutrition Delta. De innovatie op boerderijniveau wordt geacht hier veel meer te verlopen via de grote bedrijven in de toelevering en voedselverwerking die belang hebben bij innovatie op boerderijniveau.

De agrofoodsector is bij uitstek een sector die meer en meer te maken heeft met maatschappelijke randvoorwaarden, zoals dierenwelzijn, klimaatmaatregelen en dergelijke. De opgave om op duurzame wijze voldoende voedsel te produceren, waarbij ook de kosten en baten evenwichtig over de ketenschakels worden verdeeld, vergt een systeeminnovatie op vele fronten. Systeeminnovaties zijn bij uitstek complexe veranderingsprocessen, die zowel technische, organisatorische en marktinnovatie vragen en waarbij interactie tussen ondernemers, beleid en maatschappij belangrijk is. Waar in het verleden de primaire sector de belangrijkste vertegenwoordiging van het bedrijfsleven in de gouden driehoek was, is dit het laatste decennium drastisch veranderd. Een breed scala aan bedrijven uit de hele keten, maar ook ngo's, participeert nu in de genoemde driehoek en geeft innovaties in gezamenlijkheid vorm.

Innovatie op allerlei niveaus is dus een belangrijke voorwaarde om de Nederlandse land- en tuinbouw onderscheidend en concurrerend te houden. Agrarische ondernemers nemen hiertoe dikwijls zelf het initiatief, maar werken daarbij wel vaak samen met collega's, het 'grote' bedrijfsleven, kennisinstellingen en overheden.

\subsection{Innovatie}

1. Wat is innovatie?

2. Wie innoveert?

3. Hoe meten/schatten we de inkomsten van die innovaties?

4. Welke trends en ontwikkelingen doen zich hierin voor?

5. Welk beleid zou de provincie Zuid-Holland kunnen voeren ten aanzien van innovatie in de grondgebonden landbouw?

Door de provincie is aan LEI Wageningen UR ook de vraag gesteld wat investeringen in innovatie in de grondgebonden landbouw op leveren, maar voor de beantwoording van deze vraag is meer onderzoek nodig.

We onderscheiden de volgende vormen van innovatie:

- eerste introductie of ingebruikname

- technische of procesinnovaties

- productinnovaties 
- keteninnovaties, waaronder nieuwe businessmodellen voor korte ketens

- systeeminnovaties, bijvoorbeeld van gangbare naar biologische landbouw

- sociale innovaties, bijvoorbeeld door nieuwe netwerken en instituties te creëren.

Bij innovatie zijn onder andere de volgende partijen betrokken c.q. te onderscheiden:

- individuele primaire ondernemers

- individuele ondernemers samen met collega's, bijvoorbeeld in producentenorganisaties

- individuele of groepen ondernemer samen met ketenpartijen - veredelaars, afnemers

- individuele of groepen ondernemers samen met dienstverleners - landbouwmechanisatiebedrijven, adviseurs, ontwerpers.

\section{Wat levert innovatie op?}

Voor primaire ondernemers kan het leiden tot hogere opbrengst en/of kwaliteit, hogere toegevoegde waarde, hogere arbeidsproductiviteit en/of lagere kosten. Voor ketenpartijen gaat het hierbij om een groter onderscheidend vermogen, beter scoren op nichemarkten en ook een hogere toegevoegde waarde. Voor dienstverleners gaat het veelal om een hogere omzet. De regionale economie kan door innovatie gestimuleerd worden middels versterking van het ondernemerschap en van de regionale vitaliteit, nieuwe netwerken, naamsbekendheid, export en meer omzet, winst en werkgelegenheid.

De inkomsten en ook de kosten van innovaties zijn over het algemeen fase-afhankelijk (Figuur 4.1). Het huidige instrumentarium van subsidies en fiscaliteiten is vooral geschikt om de ontwikkeling van eerste prototypes (subsidies) of een brede uitrol van perspectiefrijke innovaties (fiscale instrumenten) te ondersteunen. Vooral in de fase van opschaling van eerste prototypen naar marktintroducties zijn de financiële risico's groot te noemen. Hiervoor is overigens wel in het kader van het Gemeenschappelijk Landbouwbeleid van de EU de Garantieregeling Marktintroductie Innovaties geïntroduceerd. Daar kunnen de provincie en andere betrokken stakeholders ook gebruik van maken.

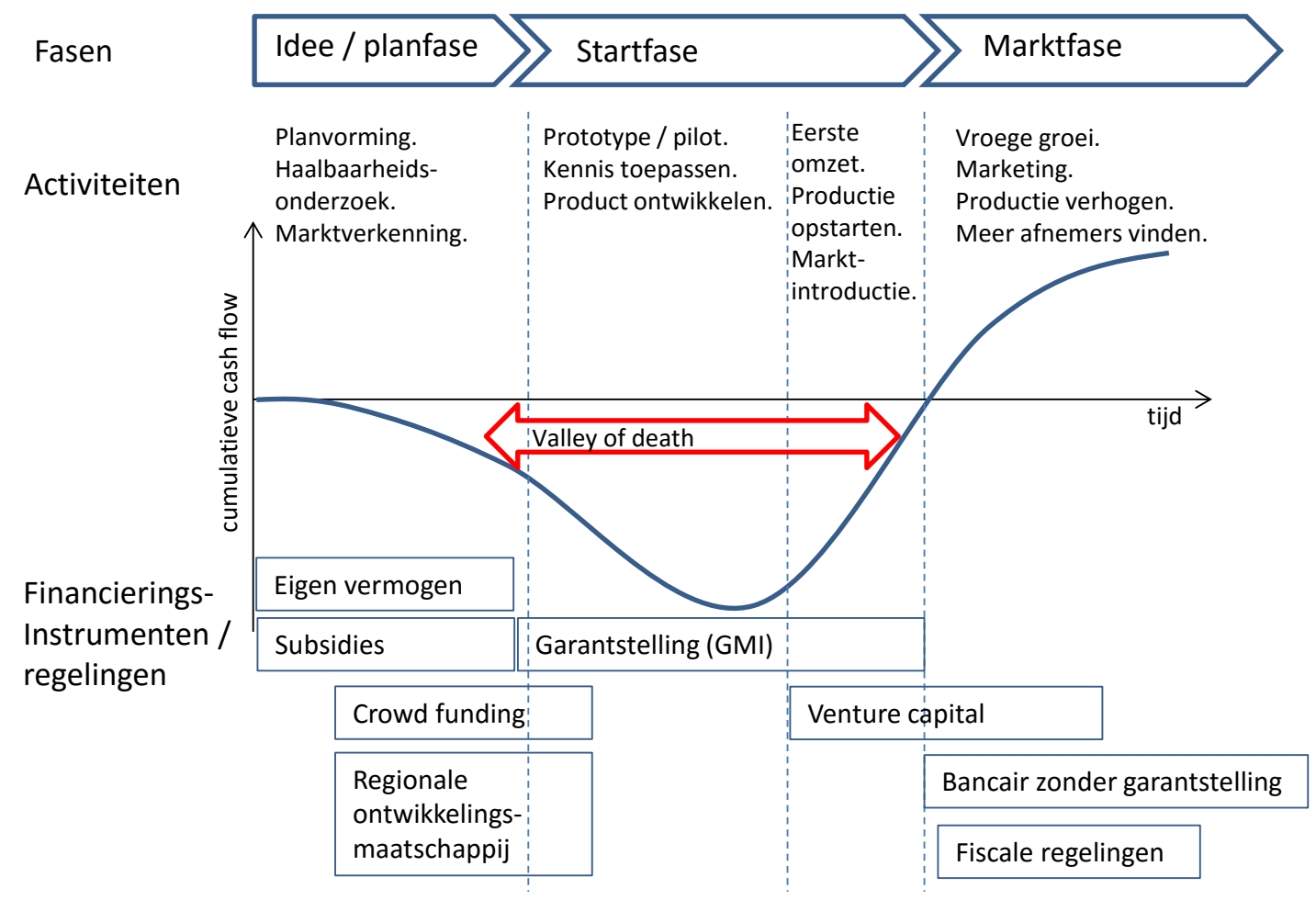

Figuur 4.1 Innovatiefasen en hun financieringsinstrumenten Bron: LEI Wageningen UR (Van der Meulen et al., 2014). 
Hoe kan de provincie Zuid-Holland in innovatie in de grondgebonden landbouw investeren? De provincie kan hiervoor met name putten uit $\mathrm{POP}^{6}$ en daarin weer met name uit:

- Prioriteit 1

bevordering kennisoverdracht en innovatie in landbouw- en bosbouwsector en plattelandsgebieden

- Prioriteit 2

versterken levensvatbaarheid en concurrentievermogen landbouwbedrijven in alle regio's; bevorderen innovatieve landbouwtechnologieën en duurzaam bosbeheer.

Cofinanciering is hierbij een voorwaarde. POP3 is gestart in 2015, maar er zijn nog geen data beschikbaar over de bestedingen in dat kader. De desbetreffende data uit POP2 zijn niet op provinciaal niveau beschikbaar en kunnen hier dan ook niet weergegeven worden.

In welke innovatiethema's kan de provincie Zuid-Holland dan investeren? Daarbij gaat het in eerste instantie om maatregelen voor innovatie en verduurzaming van de landbouw uit POP3:

- Paragraaf 2.1: Trainingen, workshops, ondernemingscoaching en demonstraties

- Paragraaf 2.2: Fysieke investeringen voor innovatie en modernisering van agrarische ondernemingen

- Paragraaf 2.3: Fysieke investeringen verduurzaming agrarische ondernemingen jonge landbouwers

- Paragraaf 2.7: Samenwerken voor innovaties

- Paragraaf 2.8.: Samenwerken in het kader van Europees Innovatie Partnerschap (EIP).

De begroting voor de Zuid-Hollandse invulling van POP3 bedraagt voor de periode 2014-2020 $€ 54,4$ miljoen. Daarvan is $€ 1,7$ miljoen bestemd voor doel $1-5$, te weten 'Sterke positie voor duurzame ecologische en rendabele grondgebonden landbouw'. Overige bronnen waaruit geput zou kunnen worden zijn Horizon 2020, Life+, Interreg en het Operationeel Programma Kansen voor West II (met name voor de mkb-sector).

\section{Hoe meten/schatten we de inkomsten van innovaties?}

Bij primaire ondernemers gaat het in dit geval om hogere opbrengsten c.q. kwaliteit van de producten, een hogere toegevoegde waarde, een hogere arbeidsproductiviteit en lagere kosten. Bij ketenpartijen gaat het in dit geval om een hogere toegevoegde waarde, net als bij de dienstverleners. Bij de regionale economie kan gekeken worden naar omzet, winst en werkgelegenheid. Hierbij moet wel aangetekend worden dat de inkomsten van innovaties niet altijd eenduidig vast te stellen zijn. Niet elke toename in omzet, toegevoegde waarde, opbrengst of productiviteit is toe te schrijven aan innovatie. Het kan ook gaan om prijsfluctuaties of 'gewone' uitbreidingen van de productie. De vraag is dan hoe hiervoor te corrigeren. Daartoe zou een trendanalyse op prijzen, productieomvang en/of productiviteit toegepast moeten worden. Ook van investeringen in innovatief vermogen en ondernemerschap, onder andere via onderwijs, zijn de inkomsten moeilijk te kwantificeren.

Uit de innovatieliteratuur inzake de agrarische sector in ons land blijkt dat vernieuwers beter scoren op rentabiliteit, inkomen en solvabiliteit en omvang in balanswaarde en Standaardopbrengsten (zie Bijlage 2 bij dit rapport). Meer specifiek voor Zuid-Holland kan dit inzichtelijk gemaakt worden met de volgende tabel (Van der Meer et al., 2014), die overigens ook betrekking heeft op de nietgrondgebonden sectoren. Daaruit blijkt dat over de periode 2010-2012 niet-vernieuwende agrarische bedrijven gemiddeld een inkomen per oaje ${ }^{7}$ behaalden van $€ 29.000$ tegenover $€ 53.000$ bij vernieuwers. De netto investeringen bij de vernieuwers waren met $€ 165.000$ twee keer zo groot als bij de niet-vernieuwers. Beide posten kunnen samenhangen met hun bedrijfsomvang, een kleine $€ 800.000$ Standaardopbrengst ofwel bijna twee keer zo groot als bij de niet-vernieuwers. Niet altijd is duidelijk of het inkomen en de investeringen groter zijn doordat de bedrijven van de vernieuwers groter zijn of dat vernieuwers een grotere bedrijfsomvang weten te realiseren door hun innoverende

\footnotetext{
6 POP = Plattelandsontwikkelingsprogramma, bedoeld om activiteiten en projecten gericht op het behoud en de versterking van de leefbaarheid op het platteland te bevorderen.

7 Oaje = onbetaalde arbeidsjaareenheid: dit betreft de agrarische ondernemer en de eventueel op het bedrijf meewerkende gezinsleden.
} 
houding. In ieder geval scoren vernieuwers op bedrijfseconomisch gebied beter dan niet-vernieuwers en daarbij wordt vaak ook meer aandacht besteed aan duurzaamheid.

Tabel 4.1

Financiële kengetallen van vernieuwers (innovatoren en volgers) en niet-vernieuwers, gemiddeld 2010-2012

\begin{tabular}{|c|c|c|c|c|c|c|c|c|}
\hline & \multicolumn{2}{|c|}{ Glastuinbouwbedrijven } & \multicolumn{2}{|c|}{ Varkensbedrijven } & \multicolumn{2}{|c|}{ Melkveebedrijven } & \multicolumn{2}{|c|}{ Totaal } \\
\hline Rentabiliteit & 92 & & 92 & 94 & 86 & 93 & 88 & 94 \\
\hline Inkomen uit bedrijf per oaje & 43 & 86 & 22 & 39 & 29 & 49 & 29 & 53 \\
\hline Solvabiliteit & 54 & 38 & 53 & 47 & 72 & 73 & 66 & 63 \\
\hline Eindbalanswaarde leningen & 1.300 & 3.933 & 778 & 1.841 & 787 & 772 & 851 & 1.441 \\
\hline Omvang (euro SO) & 1.156 & 2.482 & 557 & 1.101 & 271 & 298 & 426 & 796 \\
\hline
\end{tabular}

Vern. = vernieuwer

Bron: Bedrijveninformatienet van LEI Wageningen UR en Innovatie-enquête

Wanneer we de inkomsten van innovaties willen meten of schatten komen we op grond van de Innovatie-monitor van het LEI (Van der Meer et al., 2014) voor de primaire bedrijven in de land- en tuinbouw in Zuid-Holland tot de volgende formule:

1. Schat het aantal vernieuwers in de sector $=$ voorlopers + (vroege) volgers.

2. Schat de percentages hogere omzet + inkomen ten opzichte van niet-vernieuwers en druk deze uit in concrete bedragen per bedrijf.

3. Corrigeer voor een betere uitgangssituatie voor wat betreft de omvang van de bedrijven door middels van een coëfficiënt.

4. Bereken de investeringen van de provincie + andere overheden in innovatie.

De inkomsten kunnen dan uitgedrukt worden in de vorm van de volgende multiplier: $((1 * 2 * 3) / 4) *$ $100 \%$. Bij gebrek aan gegevens hebben we deze berekening voor Zuid-Holland niet concreet uit kunnen voeren.

Voor ketens zouden de inkomsten als volgt kunnen worden berekend:

1. Bereken omzet en werkgelegenheid van de schakels in de grondgebonden sectoren uit de Agrarische input-outputtabel uit het verleden, bijvoorbeeld vanaf 2010 (zie ook Blokland et al., 2010).

2. Idem in het meest recente jaar, zie de update in hoofdstuk 3.

3. Corrigeer de omzet in de primaire sectoren voor de prijsindex van de producten in de grondgebonden sectoren en druk deze uit in een coëfficiënt.

4. Corrigeer de omzet ketenschakels voor inflatie en druk deze uit in een coëfficiënt.

5. Bereken de investering van de provincie per schakel; de multiplier per schakel is dan:( (2 - 1$)$ * (3 of 4 ) / 5) *100\%.

Ook hier hebben we wegens gebrek aan gegevens deze berekening niet uit kunnen voeren.

De kernvraag is voor de provincie: wat leveren investeringen in innovatie in de grondgebonden landbouw op? In het tijdsbestek van deze studie is het niet mogelijk gebleken om de bovengenoemde multipliers daadwerkelijk aan de gedane investeringen te koppelen. Daarvoor is vervolgonderzoek nodig. 


\subsection{Trends en ontwikkelingen}

In en om de agrarische sector doen zich verschillende trends en ontwikkelingen voor die vragen om innovaties op verschillende niveaus. Die innovaties zijn nodig om de sector een goed perspectief te geven, ook in relatie tot ketenpartijen en maatschappelijke actoren zoals stadsbewoners.

De belangrijkste trend in de grondgebonden landbouw, ook in Zuid-Holland, is en blijft schaalvergroting.

Innovaties die op dat vlak aan de orde kunnen zijn (en die ook gericht zijn op duurzaamheid), zijn kavelruil (noodzakelijk voor beperking transportbewegingen en om de 'koe in de wei' beter mogelijk te maken bij toenemende koppelgrootte), ICT (noodzakelijk voor grotere arbeidsproductiviteit per hectare en/of meer koeien per arbeidskracht) en precisielandbouw/smart farming.

Daarnaast zijn ook verduurzaming en/of kwaliteitsverbetering van producten belangrijke trends op het gebied van innovatie. Dit kan onder andere door:

- verhoging van inputefficiëntie door precisielandbouw/smart farming

- verlaging van inzet van meststoffen en gewasbeschermingsmiddelen door een grotere mate van resistentie, precisielandbouw en drone-waarnemingen

- naast resistentieveredeling rassen met meer smaak.

Een ander speerpunt voor innovaties in de grondgebonden landbouw is de noodzakelijke verlaging van de emissies van broeikasgassen. Mogelijke innovaties op dit gebied zijn:

- verlaging van energiegebruik door middel van innovaties in motoren en warmteterugwinningssystemen

- toename in gebruik van alternatieve energiebronnen voor motoren, zoals elektra, waterstof, koolzaadolie

- toename in productie van duurzame energie op landbouwbedrijven

- afname van lachgas- en methaanemissie door middel van innovaties in stal-, mest- en bemestingssystemen.

De provincie zou sterker in kunnen zetten op versterking van de biobased c.q. de circulaire economie.

Nieuwe verdienmodellen voor agrarische ondernemers staan ook sterk in de belangstelling:

- specifieke producten, kwaliteiten, niches enzovoort, eventueel als korte keten

- natuurinclusieve landbouw ontwikkelt door collectieven voor agrarisch natuurbeheer;

- verbreding, diversificatie en samenwerking

- zilte landbouw als kans in de Zuid-Hollands Delta.

Belangrijk hierbij is de toenemende belangstelling vanuit de stad voor de ontwikkelingen op het platteland. Veel partijen zoeken naar andere en nieuwe organisatievormen voor boer-burgerrelaties en ook naar combinaties van stadslandbouw, waardoor de voedselproductie dichter bij de burger gebracht kan worden. Sommige afnemers stimuleren boeren ook om zich meer op maatschappelijke opgaven te richten. Zo wordt weidegang nu al vanuit meerdere zuivelondernemingen extra beloond in de melkprijs en is het stimuleren van biodiversiteit een nieuw element dat ook langs die weg extra beloond gaat worden.

Ten slotte is hierbij verbetering en versterking van het ondernemerschap van agrariërs aan de orde. Daarbij kan ook gekeken worden naar de wijze waarop agrarische ondernemers opgeleid worden. De indruk bestaat dat, met name in de veehouderij-opleidingen op het mbo en hbo, de aandacht voor het ondernemerschap vrij eenzijdig gericht wordt op verhoging van de productiviteit op de bedrijven. Het zou goed zijn als ondernemers in opleiding ook meegenomen worden in mogelijke innovaties in de bedrijfsvoering die een breder maatschappelijk doel dienen.

In en om de agrarische sector doen zich dus verschillende trends en ontwikkelingen voor die vragen om innovaties op verschillende niveaus. Die innovaties zijn nodig om de sector een goed perspectief te geven, ook in relatie met ketenpartijen en maatschappelijke actoren zoals stadsbewoners. 


\subsection{Mogelijkheden voor provinciaal beleid}

Naast een noodzaak voor innovaties zijn er zeker ook mogelijkheden voor provinciaal beleid inzake innovatie in de grondgebonden landbouw. De provincie zou daarbij met name kunnen inzetten op thema's van regionale aard. De provincie Zuid-Holland zou zich meer specifiek kunnen richten op de volgende mogelijke innovaties in haar grondgebonden landbouw:

- experimenten door boeren met nieuwe rassen (gewassen en dieren), melk- en stalsystemen

- experimenten door boeren met nieuwe bedrijfssystemen, onder andere om bodemdaling tegen te gaan

- grootschalige adoptie van ICT en inzetten op Big Data, ook om duurzaamheid te stimuleren

- kavelruil en bedrijfsverplaatsing om een meer duurzame bedrijfsvoering mogelijk te maken

- aanpassing weg- en watersystemen, met name om logistieke problemen te ondervangen

- creëren van ruimte voor nieuwe verdienmodellen en meer co-creatie tussen consumenten en producenten, onder andere via korte ketens.

$\mathrm{Er}$ is in de provincie dus zeker aanleiding voor innovatie in de grondgebonden landbouw en er zijn ook veel mogelijke thema's en partijen in beeld om hiermee concreet aan de slag te gaan. Bij mogelijke investeringen van de provincie op dit gebied kan vooral gedacht worden aan specifieke regionale innovaties, zoals:

- verkaveling, weg- en watersystemen

- relatie stad en land, consumenten, korte ketens

- betere kwaliteit van water, lucht, natuur.

Wel zijn er meer data en berekeningen nodig voor een inschatting van de mogelijke inkomsten van dergelijke innovaties.

Wat er moet veranderen in de grondgebonden landbouw, ook in Zuid-Holland, om innovatie meer de ruimte te geven is het volgende:

- stimuleren en faciliteren van experimenten door (groepen van) boeren;

- grootschalige adoptie van ICT en inzetten op Big Data, ook om duurzaamheid te managen (onder andere precisielandbouw);

- meer co-creatie tussen consumenten en producenten onder andere via het stimuleren van korte ketens

- het creëren van ruimte om nieuwe verdienmodellen voor agrariërs te ontwikkelen.

Als mogelijke provinciale beleidsmaatregelen hiervoor kunnen gezien worden:

- de inzet van het EIP uit POP3 voor innovaties ten aanzien van de meervoudige benutting van landbouwproducten en voor samenwerking tussen ondernemers, bijvoorbeeld in de vorm van het opzetten van kenniskringen voor innovaties

- investeringssteun voor innovatieve bedrijven

- garantstelling voor investeringen van agrarische ondernemers in innovaties. 


\section{$5 \quad$ Korte ketens}

\section{$5.1 \quad$ Inleiding}

Door verschillende ontwikkelingen in de keten en in de maatschappij is er momenteel veel belangstelling voor het tot stand brengen van zogenoemde 'korte ketens' in en om de landbouw in ons land. De (organisatorische en fysieke) afstand tussen primaire producenten (boer en tuinder) en de consumenten is in dergelijke ketens kleiner dan in de gangbare, dikwijls grootschalige ketens.

Zowel in Nederland als in de EU speelt in toenemende mate de discussie over de geringe macht van de primaire producenten in de keten. Geconstateerd wordt allerwegen dat die macht de afgelopen decennia sterk afgenomen is en dat heeft volgens velen ook gevolgen gehad voor de prijs die de primaire producenten voor hun producten krijgen. Deze wordt in toenemende mate bepaald door een beperkt aantal ketens van grote supermarkten. Daarom klinkt in met name Noordwest-Europa de roep om meer rechtvaardige ketens, waarin de primaire producten een prijs voor hun producten krijgen die recht doet aan de inspanningen die politiek en maatschappij van ze vereisen, en de daaruit resulterende kostprijs.

We beginnen met een schets van de begrippen ketenverkorting en -omkering en geven we aan wat dit kan betekenen voor de verdienmodellen van agrarische ondernemers. Ook schetsen we het belang van hernieuwde relaties tussen producenten en consumenten, mede met het oog op het versterken van de 'licence to produce' van de agrarische sector in ons land. Vervolgens gaan we in op de groeiende betekenis van en de kansen voor korte ketens in Zuid-Holland. Daarna besteden we aandacht aan het onderwerp 'Gemeenschappelijk landbouwbeleid en korte ketens', waarna in paragraaf 5.5 conclusies volgen.

\subsection{Ketenverkorting en -omkering}

Er zijn in politiek en maatschappij een aantal ontwikkelingen gaande die leiden tot vragen om ketenverkorting en ketenomkering (deze begrippen worden hieronder toegelicht). Zo zien we wereldwijd een toenemende trend dat meer mensen voedsel uit langere ketens proberen te vermijden en vaker producten kopen die dichter bij huis worden geproduceerd. Boerenmarkten en groenteabonnementen zijn in opkomst, maar ook supermarkten profileren zich steeds meer met boeren uit de regio en restaurants kopen direct in bij de boer. Voedingsbedrijven kopen hun grondstoffen steeds minder in op anonieme markten en steeds meer via bekende toeleveranciers. Deze trend heeft onder andere te maken met (gepercipieerde) gezondheidsvoordelen van versketens (ook deze term wordt hieronder toegelicht), maar ook met milieuproblemen die samenhangen met het transport van voedsel en voedingsingrediënten over grote afstanden (uitgedrukt in zogenoemde food miles). Daarnaast spelen vragen over arbeids- en milieuomstandigheden of een eerlijke verdeling van schaarse grondstoffen een rol.

Ook is er een gebrek aan transparantie in de keten. Producenten- en consumentenorganisaties wijzen steeds op de afnemende geloofwaardigheid van gevestigde instituties, zowel van bedrijven en certificerende instanties, evenals van overheden en controlerende instanties (zoals bij de EHEC-crisis of de paardenvlees-affaire bleek). Het Nederlandse exportmodel is gebaseerd op een grenzeloos vertrouwen in de instituties die de Europese en internationale handel reguleren (kwaliteit, voedselveiligheid, financiering). Deze instituties blijken niet altijd goed te werken of worden zelf speelbal van particuliere sentimenten en belangen. Daarom is er een toenemende behoefte aan tegenwicht tegen de grote industriële en retailbelangen die de ontwikkelingen in de keten beheersen en bepalen. Dat tegenwicht komt zowel van consumenten als van primaire producenten. Consumenten kiezen steeds vaker voor producten uit korte ketens en primaire producenten verenigen zich in producenten- 
organisaties om gezamenlijk een vuist te kunnen maken tegen de andere ketenpartijen waar zij mee te maken hebben (zie onder andere van der Schans et al., 2015).

Dit alles betekent, mede gezien het verdienmodel van de primaire sector, dat ketenomkering en verkorting een steeds belangrijkere rol gaat spelen inzake de toekomst van de land- en tuinbouw in ons land. Bij ketenverkorting gaat om het verminderen van het aantal schakels tussen producent en consument (zie ook paragraaf 4.2). Dit betekent allereerst een mogelijke verbetering van de ketenmarge voor de overgebleven schakels in de keten. Maar het betekent ook een meer overzichtelijke keten, waarbij duidelijker is waar het product vandaan komt, onder welke voorwaarden het is geproduceerd, verwerkt en gedistribueerd, en welke partijen een rol spelen in de waardeketen. Dit geldt vooral voor de versketens (rechtstreekse levering aan supermarkten en/of aan eindconsumenten), maar in toenemende mate zien we dit ook optreden in ketens van bewerkte producten (bijvoorbeeld de fritesindustrie koopt rechtstreeks in bij de boer).

$\mathrm{Er}$ is dus door verschillende ontwikkelingen in de keten en in de maatschappij veel belangstelling voor het tot stand brengen van zogenoemde 'korte ketens'. De (organisatorische en fysieke) afstand tussen primaire producenten (boer en tuinder) en de consumenten is in dergelijke ketens kleiner dan in de gangbare, dikwijls grootschalige ketens. Dat spreekt zowel consumenten als producenten aan.

\subsection{Groeiende betekenis van en kansen voor korte ketens}

Het is lastig de economische betekenis van korte ketens in Zuid-Holland te kwantificeren. Maar er zijn wel aanwijzingen dat ze van toenemend belang zijn. Daar zijn ook kansen voor, waarbij de provincie Zuid-Holland in principe een stimulerende rol kan spelen.

De eerste vraag is wat nu precies onder een korte keten verstaan kan worden. Wij hanteren hier de definitie dat een korte keten 0 schakels tot 1 schakel bevat tussen producent en consument. Hierbij gaat het veelal om rechtstreekse verkoop van producent naar consument ( 0 schakels), of via een tussenpersoon, bijvoorbeeld een slager (1 schakel). Logistiek kan ook een schakel zijn. Deze definitie sluit veel activiteiten op dit gebied uit, maar geeft wel duidelijkheid. Er kan eventueel ook nog een maximale geografische afstand aan gekoppeld worden. In de EU geldt hiervoor een grens van maximaal 80 tot $100 \mathrm{~km}$. In de Nederlandse context wordt dit meestal beperkt tot maximaal 25 tot $40 \mathrm{~km}$.

De volgende kanalen worden onderscheiden:

- Huisverkoop van agrarische ondernemers

- Korte keteninitiatieven als Willem \& Drees

- Boerenmarkten: bijvoorbeeld Rotterdamse Oogstmarkten

- Internetverkoop: Willem \& Drees, Rechtstreeks, enzovoort

- Horeca: Deli XL, Vers 24/7

- (Regionale) supermarkten als Hoogvliet en Plus

- Marqt

- Agrimarkt

- Institutionele catering: Sodexo, Albron, enzovoort

- (Regionale) tuincentra.

Om iets te kunnen zeggen over de economische betekenis van de korte ketens in de Zuid-Hollandse grondgebonden landbouw zijn we in eerste instantie te rade gegaan bij het Bedrijveninformatienet (Informatienet) van het LEI. Uit een inventarisatie van gegevens daaruit bleek in 2012 dat 17 agrarische bedrijven in Zuid-Holland zich bezighielden met huisverkoop (Van der Schans, 2012). De exacte omzet daarvan was niet bekend. Aanvullend hebben we een aantal van de betrokken bedrijven uit Zuid-Holland benaderd met de vraag welke omzet zij nu draaien in de korte ketens en welke omzet zij daarbij op termijn verwachten. Daaruit zijn de volgende gegevens naar voren gekomen:

- een toonaangevend tuinbouwbedrijf in Zuid-Holland meldt recent dat men in 2015 ongeveer $1 \%$ van de omzet in korte ketens afgezet heeft. Men verwacht in dat segment wel een omzetstijging van 10 tot $15 \%$ in de komende 15 jaar. 
- een van de partijen die zich in Zuid-Holland vanuit de keten bezighoudt met het verwerken en verkopen van streekproducten, geeft aan dat zij in 2015 op dat vlak een omzet van circa 100.000 euro behaald heeft en verwacht dat die omzet de komende 5 jaar met $5 \%$ zal groeien.

- een volgende indicatie komt van een andere ketenpartij, die aangeeft dat men in 2015 een omzet van 300.000 euro gerealiseerd heeft in korte ketens en in 2016 een verdubbeling daarvan verwacht.

- een van de partijen die zich bezighoudt met de verkoop van streekproducten in Zuid-Holland meldt dat men in 2016 een omzet van bijna 1 miljoen euro denkt te gaan realiseren. Men verwacht die omzet de komende 2 jaar te kunnen verdubbelen en ook het aantal verkooppunten uit te kunnen breiden.

- een partij uit Zuid-Holland die ook landelijk actief is meldt dat zij in 2015 bijna 8 miljoen euro omgezet heeft in korte ketens. Dat betreft wel een landelijk cijfer, wat verder niet provinciaal uitgesplitst kon worden. Naar verwachting stijgt die landelijke omzet in 2016 naar iets meer dan 14 miljoen euro.

Er is dus duidelijke een stijgende lijn te zien, maar een meer gedetailleerde en onderbouwde inschatting van de (mogelijke) omzet van korte ketens in de grondgebonden landbouw in Zuid-Holland vereist een nader onderzoek.

Korte ketens in Zuid-Holland hebben zeker groeipotentie. Daarvan is op basis van consumentenprofielen een inschatting gemaakt in een rapport van Monteny en Van der Schans uit 2015. Daaruit blijkt dat er met name in de Rotterdamse regio een groei van de stedelijke vraag naar producten uit korte ketens mogelijk is. Overigens kan ook de glastuinbouw in de regio een motor zijn voor korte ketens.

Nader inzicht ontstaat door extrapolatie van trends in de groei van korte ketens in de grondgebonden landbouw in Zuid-Holland uit toekomstscenario's van onder andere de Rabobank. Als mogelijke 'drivers' voor die korte ketens kunnen de volgende ontwikkelingen genoemd worden:

- mogelijke alternatieven voor de supermarkten

- een andere en innovatieve organisatie van de logistiek

- verschillende beleidsdomeinen aan elkaar verbinden, zoals bijvoorbeeld voeding en gezondheid

- aanpassing van de koopomgeving: korte ketens op ooghoogte, enzovoort.

Om korte ketens te stimuleren kan de provincie gebruik maken van POP-gelden, bijvoorbeeld door het ondersteunen van Operational Groups van ondernemers in het kader van het Europese Innovatie Programma (EIP). Ook zou de provincie logistieke initiatieven van producenten in korte ketens kunnen ondersteunen, evenals het opzetten van consumentenkringen om de producten daaruit af te nemen. Met dat laatste kan ook de inkomenszekerheid van boeren die in korte ketens investeren, versterkt worden. Voor een boer of tuinder is het overstappen naar een korte keten een complexe verandering met de nodige leerprocessen en investeringen. Het is goed dat de betrokken ondernemers daarbij een steuntje in de rug krijgen.

Een trend die gezien kan worden bij consumenten en burgers is dat solidariteit met de omgeving en solidariteit met de Derde Wereld toegenomen is. Ook worden familiebedrijven weer belangrijker in de ogen van burgers. Sommige bedrijven willen juist investeren in schaalverkleining in plaats van schaalvergroting. Kijk naar de ontwikkelingen bij Lely Machinebouw, maar ook bij microbrouwerijen, en microslachterijen. Tegenwoordig is daar ook de juiste technologie voor ontwikkeld. Verwerkers kunnen nu ook schaalverkleining aan. Denk bijvoorbeeld aan een mobiel slachthuis.

Verder zien steeds meer ondernemers de voordelen van clustervorming en 'shared infrastructure'. Zo kan gebruik gemaakt worden van supermarktstructuren om een overdekte boerenmarkt op te zetten. De potentie van korte ketens ligt vooral bij de 'gewone' consument. Start ups halen eerder de consument bij andere initiatieven weg dan dat ze een nieuwe markt aanboren.

Qua logistiek zouden korte ketens ook mee kunnen liften met andere logistieke stromen. Daarbij kan ook nagedacht worden over het combineren van food- en non-foodstromen. Vraag en aanbod uit korte ketens komen steeds meer via internet bij elkaar. Zonder internet is het vaak niet mogelijk om een 
alternatief voor een supermarkt te vinden. Sociale media stimuleren ook een verscheidenheid aan initiatieven voor korte ketens.

Het is dus lastig de economische betekenis van korte ketens in Zuid-Holland te kwantificeren. Maar er zijn wel aanwijzingen dat ze van toenemend belang zijn. Daar zijn ook kansen voor, waarbij de Provincie Zuid-Holland in principe een stimulerende rol kan spelen.

\subsection{Gemeenschappelijk landbouwbeleid en korte ketens}

Het Gemeenschappelijk Landbouw Beleid (GLB) heeft tot nu toe het ontstaan van korte ketens niet bevorderd. Maar er zijn met name binnen het POP wel degelijk mogelijkheden om de ontwikkeling van korte ketens te bevorderen. De Europese Unie streeft naar een duurzame en concurrerende land- en tuinbouw en heeft dat streven vastgelegd in het GLB. Voor korte ketens zijn met name de Gemeenschappelijke Marktordening (GMO) voor Groenten en Fruit en het Plattelandsontwikkelingsprogramma (POP) van belang. Nederland heeft voor beide het Europese beleid vertaald in nationaal beleid.

Provincie Zuid-Holland wil in haar beleid voor de grondgebonden land- en tuinbouw een stimulans geven aan korte ketens via het POP. De vraag is hoe het Europese beleid ten aanzien van korte ketens verder kan worden vertaald via nationaal beleid naar provinciaal beleid en op welke wijze dat het beste vorm is te geven. Is dit via het stimuleren van producenten om zich te verenigen in horizontale samenwerkingsverbanden (= producentenorganisaties of PO's) en/of meer focus te leggen op waardetoevoeging en verduurzaming in de korte keten? In de GMO voor groenten en fruit is het oprichten van PO's een voorwaarde om in aanmerking te komen voor stimuleringsprogramma's (lees subsidies). De praktijk leert echter dat in de GMO de meeste aandacht en middelen zijn gegaan naar verduurzaming en capaciteitsvergroting van deelnemende bedrijven in de bestaande ketenstructuur, waardoor de verzadigde markt in de EU nog meer wordt overspoeld met - overigens kwalitatief goede - producten.

In de nieuwe GMO voor groenten en fruit komt de focus meer te liggen op versterking van de marktstructuur, marktgericht produceren en verdergaande verduurzaming. Het vereisen van PO's had als onbedoeld effect dat deze bedrijven vooral de focus legden op het vergroten en het efficiënter maken van de productie om de concurrentie met niet-EU-landen vol te houden en/of te verbeteren. Echter door de verzadigde markt van met name verse groenten levert een kleine verstoring van de markt grote tot zeer grote prijsfluctuaties op (prijsvolatiliteit) in zowel positieve als negatieve zin. Het Europese en nationale subsidiebeleid binnen GMO heeft daarmee onbedoeld de situatie voor de bedrijven verslechterd (prijsdaling van producten). Dit is dan ook de reden dat individuele bedrijven wanneer het kan - uit de PO's stappen en alleen of in kleiner verband verder gaan. Weliswaar zonder EU- en/of nationale subsidies, maar ook zonder de administratieve lastendruk en de regelzucht.

Voor de (overige) grondgebonden sectoren zijn geen subsidies vanuit het GMO beschikbaar. Daar heeft het GMO dus ook niet die uitwerking op schaalvergroting en prijsdaling gehad als in de groente en fruitsector. Dat beleid heeft voornamelijk invloed gehad op de glastuinbouwsector en daarnaast op de opengrondsgroenten- en de fruitteelt, twee sectoren die in Zuid-Holland relatief onbelangrijk zijn in vergelijking met de glastuinbouw.

\subsection{Conclusies}

Producenten en bedrijven moeten de bedreigingen en de kansen voor korte ketens vooral vanuit de marktkant benaderen. Het verenigen in samenwerkingsverbanden van primaire producenten is daarvan een (weliswaar belangrijke) afgeleide. Samenwerking kan nuttig om producten in voldoende omvang, breed van assortiment en van goede en identieke kwaliteit te leveren direct aan of aan de laatste schakel voor de consument. Essentieel is met name het marktgericht produceren door goed te luisteren naar de wensen van de consumenten en tegelijkertijd voldoende vooruitgang te boeken op de duurzaamheidsbarometer. 
Om de ontwikkeling van korte ketens te stimuleren zou de provincie Zuid-Holland zich dan ook in eerste instantie kunnen richten op het ondersteunen van primaire producenten die zich ten behoeve van die korte ketens organiseren in nieuwe coöperaties en/of producentenorganisaties. Die organisaties zouden vanuit de provincie ook ondersteund kunnen worden bij het zoeken naar en het vormgeven van nieuwe verdien-modellen, onder andere via investeringssteun vanuit het POP.

De provincie kan zich vervolgens bij het ondersteunen van korte ketens het beste richten op het ondersteunen van oplossingen op maat. Daarbij gaat het met name om het ondersteunen van de infrastructuur, de logistiek, de ruimtelijke ordening en het ondernemerschap van de betrokken ondernemers (onder andere via kenniskringen, masterclasses, enzovoort). 


\section{Toekomstperspectief voor de periode tot 2025}

\subsection{Toekomstverwachtingen per sector}

De verwachting is dat in de akkerbouw in Zuid-Holland de komende jaren de arealen van de voedergewassen en granen nog toe zullen nemen. De arealen van de hoogsalderende gewassen in deze sector zullen afnemen. De opbrengstprijs van suikerbieten zal naar beneden gaan en daardoor ook het areaal. Het aantal melkveehouders in Zuid-Holland zal de komende jaren, conform het landelijk beeld, afnemen. Het aantal melkkoeien neemt tot 2025 naar verwachting toe met circa $8 \%$. Dat is minder dan de landelijke verwachting (+ 20\%), wat komt doordat de komende fosfaatquotering een forse rem op de groei zal zetten. De melkproductie per koe zal blijven stijgen. De melkproductie per ha zal naar verwachting toenemen. Grondruil met akkerbouwers zal verder in belang toenemen.

Momenteel verkeert de melkveehouderijsector in ons land in zwaar weer. Sinds de afschaffing van het melkquotum in 2015 is het aantal melkkoeien in Nederland sterk gestegen. Mede daardoor is de melkprijs fors gedaald, waardoor op diverse bedrijven liquiditeitsproblemen zijn ontstaan. Daarnaast is de mestproductie zodanig sterk gestegen dat van overheidswege de melkveehouderij grondgebonden moest worden. Dat gaat onder andere tot de invoering van fosfaatrechten leiden. Schaalvergroting van blijvende melkveebedrijven zal veel geld gaan kosten, omdat naast grond ook fosfaatrechten aangekocht moeten worden. Op dit moment is moeilijk te voorspellen welke structuurverandering zich de komende jaren zal voordoen door de beschreven ontwikkelingen.

\subsection{Verwachte arealen, veestapel en aantallen bedrijven in 2025}

\section{Gewasarealen}

$\mathrm{Er}$ is een inschatting gemaakt van de te verwachten gewasarealen in Zuid-Holland in 2025. In Tabel 6.1 zijn deze arealen weergegeven, waarbij er rekening mee is gehouden dat de komende tien jaar ongeveer 8.000 ha aan het landbouwareaal in Zuid-Holland zal worden onttrokken voor de ontwikkeling van andere (niet-agrarische) sectoren. Ter vergelijking zijn ook de arealen anno 2015 in de tabel opgenomen. De belangrijkste uitkomst van de inschatting zoals weergegeven in Tabel 6.1, is dat de voedergewassen en granen de komende jaren iets in belang toe zullen nemen en dat het belang van de hoogsalderende gewassen aardappelen, suikerbieten en tuinbouw zal gaan afnemen. Over de hele linie wordt een daling van het areaal cultuurgrond verwacht.

Tabel 6.1

Geregistreerde en te verwachten gewasarealen in Zuid-Holland in 2015 en 2025 (in ha)

\begin{tabular}{lrr} 
Gewasgroep & 2015 & 2025 \\
Granen & 15.720 & 960 \\
\hline Zaden & 10.090 & 670 \\
\hline Aardappelen & 3.470 & 8.870 \\
\hline Suikerbieten & 1.930 \\
\hline Groenvoedergewas & 12.260 & 13.470 \\
\hline Tuinbouw & 12.460 & 10.990 \\
\hline Grasland & 67.900 & 66.500 \\
\hline Overig grondgebonden & 1.150 & 730 \\
\hline Cultuurgrond totaal & 128.820 & 121.290 \\
\hline
\end{tabular}

Bron: Inschattingen LEI op basis van trendmatige ontwikkelingen uit CBS-Landbouwtelling. 


\section{Veestapel}

Evenals voor de gewasarealen is ook voor de veestapel een inschatting gemaakt van de te verwachten omvang in de komende jaren (Tabel 6.2). Verwacht wordt dat het aantal melkkoeien in Zuid-Holland in de komende 10 jaar met $8 \%$ zal toenemen (met bijbehorend jongvee). De aantallen vleesrunderen, paarden en schapen zullen naar verwachting de komende jaren gaan krimpen. Het aantal geiten heeft de afgelopen jaren een sterke stijging doorgemaakt. Deze zet zich door. De verwachting is dat deze nog met een kwart zal doorgroeien.

\section{Tabel 6.2}

Huidige en te verwachten veestapel in Zuid-Holland in 2015 en 2025 (in aantallen dieren)

\begin{tabular}{lrr} 
Diersoort & 2015 & 2025 \\
Melkkoe & 100.540 & 108.140 \\
\hline Jongvee $<1$ jaar & 34.380 & 37.430 \\
\hline Jongvee $>1$ jaar & 37.030 & 42.250 \\
\hline Vleesrund & 13.790 & 10.1840 \\
\hline Paard en pony & 11.470 & 85.770 \\
\hline Lam/schaap & 109.560 & 19.010 \\
\hline Geit & 14.980 & \\
\hline
\end{tabular}

Bron: Inschattingen LEI op basis van trendmatige ontwikkelingen uit CBS-Landbouwtelling.

\section{Aantal bedrijven en gemiddelde bedrijfsomvang}

Aan de hand van het aantal te verwachten dieren en de ontwikkelingen in schaalgrootte is het aantal land- en tuinbouwbedrijven in Zuid-Holland in de periode 2015-2025 geschat (Tabel 6.3). Daaruit blijkt een afname van het aantal bedrijven met bijna $2 \%$ per jaar. Dat percentage ligt op eenzelfde niveau als in de afgelopen jaren (2003-2015). Hierbij is geen rekening gehouden met een eventueel sterkere daling door de problemen met melkprijzen en mestafzet in het voorjaar van 2016. De totale omvang van de sector zal daardoor echter nauwelijks beïnvloed worden. Op basis van de schattingen van aantallen bedrijven, arealen c.q. dieren in de grondgebonden bedrijfstypen is de gemiddelde bedrijfsomvang voor 2025 geschat (Tabel 6.4). Voor de gangbare akkerbouwbedrijven neemt deze met 4 hectare toe $(+8 \%)$. Voor de melkveebedrijven is dit met $35 \%$ aanzienlijk groter. De groei van de biologische melkveebedrijven ligt hier met $20 \%$ tussenin. In de tabellen staan alleen de belangrijkste grondgebonden bedrijfstypen.

\section{Tabel 6.3}

Huidige en te verwachten aantallen gespecialiseerde bedrijven in Zuid-Holland

\begin{tabular}{|c|c|c|}
\hline Sector & 2015 & 2025 \\
\hline Akkerbouw & 737 & 630 \\
\hline Overig graasdieren & 1.211 & 1.190 \\
\hline Gemengd & 167 & 90 \\
\hline Totaal & 5.839 & 4.194 \\
\hline Totaal grondgebonden & 3.364 & 2.884 \\
\hline
\end{tabular}

Bron: Landbouwtelling 2015; 2025: Inschattingen LEI op basis van trendmatige ontwikkeling. 
Tabel 6.4

Verwachte ontwikkeling aantal hectare op akkerbouw- en melkveebedrijven naar 2025 (gangbaar en biologisch) in Zuid-Holland

\begin{tabular}{|c|c|c|c|}
\hline Gangbaar & 2010 & 2015 & 2025 \\
\hline Akkerbouw & 43,5 & 45,3 & 49 \\
\hline Melkveehouderij & 68,7 & 80,0 & 108 \\
\hline Melkveehouderij & 63,8 & 70,0 & 84 \\
\hline
\end{tabular}

Bron: Landbouwtelling 2015; 2025: Inschattingen LEI op basis van trendmatige ontwikkeling.

De groep biologische akkerbouwbedrijven in Zuid-Holland is te gering om een betrouwbare schatting van te geven. 


\section{$7 \quad$ Conclusies en aanbevelingen}

\subsection{Conclusies}

\section{Over de structuur van de grondgebonden landbouw in Zuid-Holland}

De structuur van de grondgebonden landbouw is relatief gunstig, met name van de akkerbouw en de melkveehouderij. Ook zijn de bedrijven in deze sectoren gemiddeld minder intensief dan nationaal.

In Zuid-Holland zijn de melkveehouderij, de overige graasdierbedrijven en de akkerbouwbedrijven qua aantallen bedrijven de grootste grondgebonden sectoren. Wel vertoont de totale werkgelegenheid op de grondgebonden bedrijven in Zuid-Holland sinds 2003 een dalende trend. De meeste werkgelegenheid bevindt zich op de melkveehouderijbedrijven in Zuid-Holland, maar op die bedrijven is de werkgelegenheid sinds 2003 in absolute termen ook het sterkst gedaald. Opvallend is dat op de overige graasdierbedrijven de werkgelegenheid sinds 2003 toegenomen is, namelijk met meer dan $20 \%$.

Op de grondgebonden bedrijven in Zuid-Holland treedt in alle sectoren vergrijzing op. Opvallend is dat bij alle grondgebonden bedrijfstypen in de provincie in 201560 tot soms $80 \%$ van de ondernemers 50 jaar of ouder is. In de akkerbouw en op de overige graasdier-bedrijven is een significant aandeel van de ondernemers zelfs $65^{+}$.

Gemiddeld had in 2012 20\% van de ondernemers in de grondgebonden sectoren in Zuid-Holland ouder dan 50 jaar een opvolger. De verschillen tussen de sectoren zijn evenwel groot op dit gebied. Op de melkvee- en akkerbouwbedrijven lag het percentage in dat jaar rond de $30 \%$. Op de opengrondsgroente- en overige graasdierbedrijven lagen de aandelen onder of net boven $10 \%$.

Gemiddeld zijn de structuur en het inkomen op de akkerbouw- en melkveebedrijven in Zuid-Holland beter dan gemiddeld in Nederland. Zowel de akker- als de melkveebedrijven in Zuid-Holland zijn gemiddeld groter zijn dan in Nederland als geheel. Dat resulteert in relatief hogere inkomens per bedrijf en per meewerkende ondernemer en gezinslid.

\section{Over het grondgebonden agrocluster}

De totale toegevoegde waarde van alle economische activiteiten in Zuid-Holland bedroeg volgens het CBS in 2013 ruim 124 miljard euro. Dit komt neer op iets meer dan $21 \%$ van de totale nationale toegevoegde waarde. Zuid-Holland is daarmee, wat betreft toegevoegde waarde, de grootste provincie van Nederland. Ook het totale arbeidsvolume van Zuid-Holland komt, met bijna 60.000 arbeidsjaren, uit op meer dan $21 \%$ van het Nederlandse totaal en is daarmee in 2013 de hoogste van alle provincies.

Het aandeel van het totale agrocluster, dus inclusief de voedings- en genotmiddelenindustrie die is gebaseerd op buitenlandse grondstoffen, in de totale economie van Zuid-Holland ligt voor zowel toegevoegde waarde als werkgelegenheid rond de $6 \%$. Vergeleken met het cijfer voor Nederland $(8 \%)$ is dit voor Zuid-Holland laag.

De bijdrage van de diverse schakels (primair, verwerking, toelevering en distributie) binnen een cluster verschilt sterk van cluster tot cluster. In het akkerbouwcluster en het visserijcluster wordt in Zuid-Holland relatief veel toegevoegde waarde gecreëerd in de industrieën die toeleveren aan de verwerkende industrie. Dit hangt ook samen met de aanwezigheid van de verwerkende industrie.

Het akkerbouwcluster draagt in Zuid-Holland met 31,5\% en bijna 27,5\% bij aan respectievelijk de toegevoegde waarde en de werkgelegenheid van het totale agrocluster in Zuid-Holland. Het totale akkerbouwcluster (inclusief de verwerking van buitenlandse grondstoffen) is in Zuid-Holland goed voor 
ruim 2,3 miljard euro toegevoegde waarde en bijna 24.000 arbeidsjaren werkgelegenheid. Hiervan hangt $18 \%$ samen met de productie en verwerking van binnenlandse akkerbouwproducten.

Het grondgebonden veehouderijcluster draagt in Zuid-Holland met 11,6 en 14,5\% bij aan respectievelijk de toegevoegde waarde en de werkgelegenheid van het totale agrocluster in ZuidHolland. Op de primaire melkveehouderijbedrijven zelf wordt $12 \%$ van de toegevoegde waarde en $22 \%$ van de werkgelegenheid van dit cluster gerealiseerd. Wat betreft grondgebruik is het veehouderijcluster met ruim $60 \%$ wel het belangrijkste agrocluster in Zuid-Holland.

\section{Over innovatie}

In Zuid-Holland liggen er veel kansen voor de volgende innovaties in haar grondgebonden landbouw. Daarbij kan met name gedacht worden aan:

- experimenten door boeren met nieuwe rassen (gewassen en dieren), melk- en stalsystemen

- experimenten door boeren met nieuwe bedrijfssystemen onder andere in het kader van de bodemdaling

- grootschalige adoptie van ICT en inzetten op Big Data, ook om duurzaamheid te stimuleren

- kavelruil en bedrijfsverplaatsing, gericht op structuurverbetering van de primaire bedrijven

- aanpassing weg- en watersystemen, onder andere gericht op een betere logistiek

- creëren van ruimte voor nieuwe verdienmodellen en meer co-creatie tussen consumenten en producenten, onder andere via korte ketens

- het versterken van de relatie tussen stad en land, ook gericht op recreatie en toerisme

- de productie van duurzame energie op landbouwbedrijven.

Wel zijn er meer data en berekeningen nodig voor een inschatting van de mogelijke inkomsten van dergelijke innovaties.

\section{Over korte ketens}

In Zuid-Holland liggen veel kansen voor het opzetten en stimuleren van korte ketens in de grondgebonden landbouw in de provincie. Om de ontwikkeling van die korte ketens te stimuleren zou de provincie Zuid-Holland zich in eerste instantie kunnen richten op het ondersteunen van primaire producenten die zich organiseren in nieuwe coöperaties en producentenorganisaties. Zij zouden vanuit de provincie ook ondersteund kunnen worden bij het zoeken naar en het vormgeven van nieuwe verdienmodellen, onder andere via investeringssteun.

De provincie kan zich bij het ondersteunen van korte ketens het beste richten op het ondersteunen van oplossingen op maat. Daarbij gaat het met name om het ondersteunen van de infrastructuur, de logistiek en het ondernemerschap van de betrokken ondernemers (kenniskringen, masterclasses, enzovoort). Ten slotte kan de provincie de juridische kaders en financiële risico's van korte ketens in kaart (laten) brengen en daarover de communicatie met betrokken stakeholders aangaan.

\subsection{Aanbevelingen}

\section{Structuur en innovatie}

Bij het gezond houden en maken van de bedrijfsstructuur, verduurzaming en nieuwe verdienmodellen in de grondgebonden landbouw in Zuid-Holland, zouden 'proeftuinen' voor innovatie een goede rol kunnen spelen. Het zetten van stappen richting een duurzamere, deels meer op de stad gerichte landbouw vraagt durf en creativiteit van agrarische ondernemers, maar ook van de betrokken overheden. Ondernemers leren over het algemeen het beste van ondernemers zelf en daarom is het belangrijk dat er in Zuid-Holland meer samenwerkingsverbanden opgezet worden van agrarische ondernemers om innovatieve ontwikkelingen met elkaar uit te kunnen werken en te bespreken. Het zou goed zijn als de provincie die proeftuinen actief stimuleert en eventueel ook financieel ondersteunt.

Financiering van nieuwe investeringen is momenteel een van de grootste problemen in de grondgebonden land- en tuinbouw in Zuid-Holland, mede door de lage melkprijzen. Een proeftuin voor innovatie zou daarom ook aandacht aan alternatieve financieringsvormen moeten besteden. Gebleken 
is daarbij dat er ruimte en animo is bij burgers om te participeren in medefinanciering van bedrijven, in ruil voor een persoonlijke betrokkenheid bij het bedrijf en het meedelen in de producten van het bedrijf. Dergelijke vormen van samenwerking en interactie bevorderen de relatie tussen stad en platteland en versterken de financieringskracht van agrarische bedrijven. Deze vormen zouden door de provincie actief gesteund en gepromoot kunnen worden.

\section{Innovatie}

Om innovatie in de grondgebonden landbouw meer de ruimte te geven zou de provincie het volgende kunnen doen:

- stimuleren en faciliteren van experimenten door boeren (inclusief nieuwe bedrijfssystemen)

- grootschalige adoptie van ICT en inzetten op Big Data, ook om duurzaamheid te managen (onder andere precisielandbouw)

- het ondersteunen van co-creatie tussen consumenten en producenten, onder andere via het stimuleren van korte ketens

- het creëren van ruimte om nieuwe verdienmodellen te ontwikkelen.

Mogelijke provinciale beleidsmaatregelen:

- de inzet van het EIP uit POP-3 voor innovatie ten aanzien van meervoudige benutting van landbouwproducten en voor samenwerking tussen ondernemers via het opzetten van kenniskringen over innovaties

- investeringssteun voor innovatieve bedrijven

- garantstelling voor investeringen van agrarische ondernemers in innovaties.

Investeer meer in data-opbouw en -verzameling ten aanzien van de (economische) inkomsten van innovaties in de grondgebonden landbouw.

\section{Korte ketens}

Organiseer de ruimtelijke ordening in de provincie meer flexibel, zodat korte ketens meer kansen krijgen. Verruim in dat kader ook de interpretatie van het begrip 'huisverkoop' zodat daar meer activiteiten onder kunnen vallen. Ondersteun ook de infrastructurele ontsluiting van betrokken bedrijven, zodat er mee ruimte is voor logistieke bewegingen die noodzakelijk zijn om korte ketens meer kansen te geven.

Investeer meer in data-opbouw en -verzameling ten aanzien van korte ketens in de grondgebonden landbouw. Hier ligt overigens ook een taak voor de kennisinstellingen zelf. 


\section{Literatuur en websites}

Baltussen, W.H.M., M.A. Dolman, R. Hoste, S.R.M. Janssens, J.W. Reijs en A.B. Smit, 2015. Grondstofefficiëntie in de zuivel-, varkensvlees-, aardappel- en suikerketen. Wageningen, LEI Wageningen UR (University \& Research centre), LEI Nota 2015-038 (in press).

Baltussen, W.H.M., M.A. Dolman, R. Hoste, S.R.M. Janssens en A.B. Smit, 2016. Gebruik van reststromen in de zuivel-, varkensvlees-, aardappel- en suikerketen. Wageningen, LEI Wageningen UR (University \& Research centre), LEI Nota (in wording).

Berkhout, P., H. Silvis en I. Terluin (red.), 2014. Landbouw-Economisch Bericht 2014, Den Haag, LEI-rapport 2014-013 (m.m.v. onder andere A.B. Smit).

Berkhout, P., M. van Asseldonk, J. Benninga, L. Gé, R. Hoste, B. Smit, 2015a. De kracht van het agrocluster. Het belang van de primaire landbouw voor het totale agrocomplex. Wageningen, LEI Wageningen UR (University \& Research centre), LEI Report 2015-032.

Berkhout, P., H. Silvis, I.J. Terluin, A. Pronk, D. Oudendag, M.J. Voskuilen en H. van der Meulen, 2015b. Het Landbouw-Economisch Bericht 2015, Den Haag, LEI Wageningen UR, 2015.

Blokland, P.W., J. Jager, M. van Leeuwen, A. Schouten en G. Venema, 2010. De grondgebonden landbouw in Zuid-Holland, structuur en ontwikkeling. Den Haag, LEI Wageningen UR.

Brouwer, F., B. Smit en R. Verburg, 2015. Economische prikkels voor vergroening in de landbouw, WOT Natuur \& Milieu, Wageningen UR, WOt-interne notitie (in press).

Harmsen, P., S. Lips, H. Bos (Wageningen UR-Food and Biobased Research), B. Smit, S. van Berkum, J. Helming en R. Jongeneel (LEI Wageningen UR), 2014. Suiker als grondstof voor de Nederlandse chemische industrie; gewassen, proces, beleid, Wageningen, FBR-rapport Nummer 1494,

Janssens, S.R.M. en A.B. Smit, 2000. Heeft precisielandbouw (de) toekomst? Den Haag, LEI, Rapport 1.00.02.

Jongeneel R., M van Leeuwen, D. Verhoog, PPS Market Outlook Agro\&Food, Medium Term Outlook 2015-2024. LEI, Den Haag, 2015 (unpublished).

Kortstee, H., N. Hamers-van den Berkmortel, K. de Grip, H. Hermans, B. Smit, R. Stokkers en M. de Vlas, 2011. Een leven lang leren. Voortdurende ontwikkeling van ondernemerscompetenties in kenniscoalities, Den Haag, LEI-rapport 2011-069.

Meer, R.W. van der, M.A. van Galen, 2015. Innovatie in de land- en tuinbouw 2014, Den Haag, LEI-rapport 2015-140.

Meulen, H. van der, et al. Kijk op multifunctionele landbouw, omzet- en impact 2007-2013, brochure, LEI Wageningen UR, 2014.

Meulen, van der, H., M. van Asseldonk, R. van der Meer en B. Smit, 2014. Ex-ante assessment Garantstelling Marktintroductie Innovaties (GMI) land- en tuinbouw, Wageningen, LEI Wageningen UR, Nota LEI 14-108.

Monteny, A., J.W. van der Schans. Verkennend onderzoek kansen opschaling korte voedselketens Rotterdam. Rotterdam, 2015.

Schans, van der, J.W. Marktverkenning regionaal voedsel Zuid-Holland. LEI Wageningen UR, Den Haag, 2012 (ongepubliceerd).

Schans, J.W. van der, J. Vader, T. Kuhlman, G. Splinter, M. Ruijs, B. Janssens en G. Venema, 2015. Kansen in de keten: naar een weerbare plantaardige sector in Noord-Holland, Den Haag, LEI-rapport 2015-140.

Silvis, H., D. Verhoog en M. Voskuilen, 2015. Omvang van het Nederlandse bos- en houtcomplex; Den Haag, LEI report 2015-060.

Smit, A.B., J.J. Stoorvogel en G.A.A. Wossink, 2000. A methodology to support the decision to invest in spatially variable nitrogen fertilisation. Netherlands Journal of Agricultural Science, 48, 273-290.

Smit, A.B., H.J.M. Kortstee, N.J. Jukema (PPO-agv), J. Meijaard (EIM), S. Oudmaijer (EIM), N. Idema, F. Pleijster (EIM), R.M. Braaksma (EIM) \& J. van Staalduinen (Van Staalduinen Communicatie), 2009. Samen werken aan samenwerking. LEI Wageningen UR, Den Haag, Rapport 2009-082, 233 pp.; http://edepot.wur.nl/50970 
Smit, A.B., C.J.A.M. de Bont, J.F.M. Helming, M.G.A. van Leeuwen, R.W. van der Meer, P. Berkhout, M. van Dijk, S.R.M. Janssens en J.H. Jager, 2011. Wel of geen suikerquotering? Economische gevolgen voor sector, keten, internationale marktverhoudingen en derde wereld, Den Haag, LEI-rapport 2011-056.

Smit, A.B., H. Prins, M. Litjens, A. van den Ham, J. Bijman en B.W. Zaalmink, 2015. Producentenorganisaties als instrument voor concurrentiekracht en innovatie; Uitbreiding van perspectief door het nieuwe GLB? Wageningen, LEI Wageningen UR (University \& Research centre), LEI Report i.w.

Veen, E., B. Breman en J.E. Jansma, 2012. november. Stadslandbouw. Een verkenning van groen en boer zijn in en om de stad. Wageningen UR, PPO AGV. 42 pp.

Verhoog, A.D., 2014. Het Nederlandse agrocomplex, editie 2014; Den Haag, LEI report 214-131. 


\section{Bijlage 1 Aanvullende structuurgegevens}

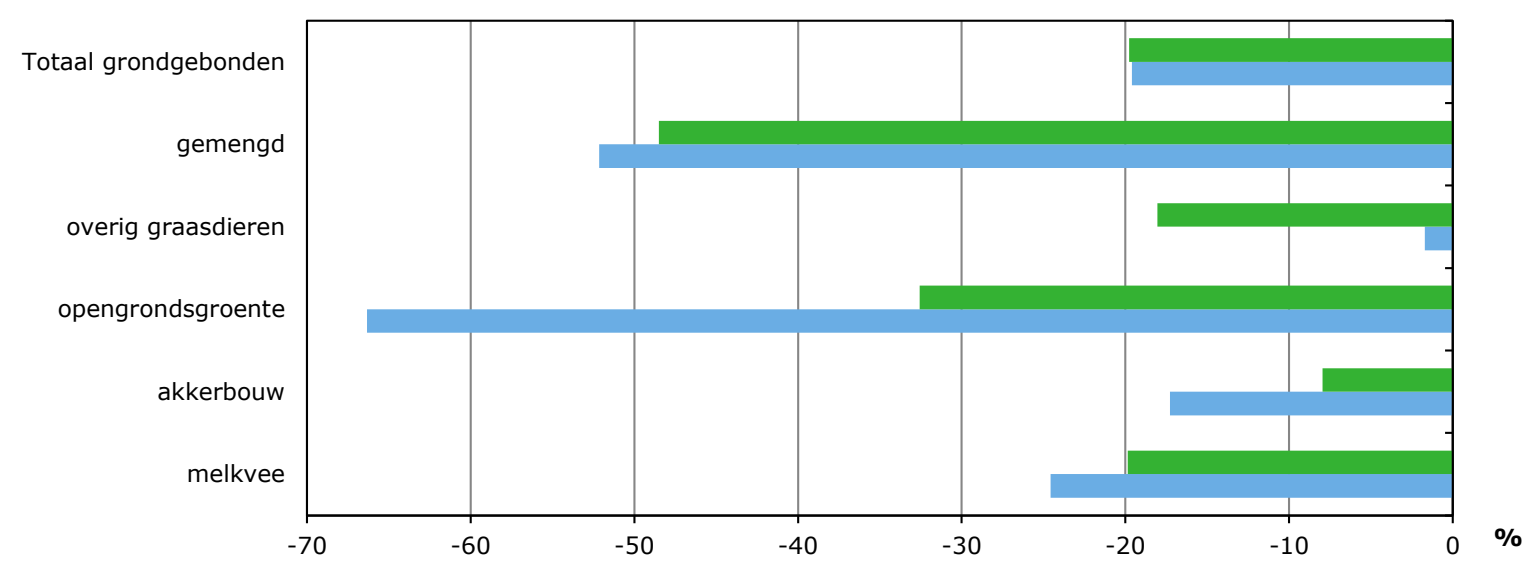

- Totaal Nederland $\quad$ Totaal Zuid-Holland

Figuur B1.1 Ontwikkeling aantallen bedrijven per type en totaal grondgebonden landbouw in 2015 ten opzichte van 2003 (in \%; index: $2003=100$ )

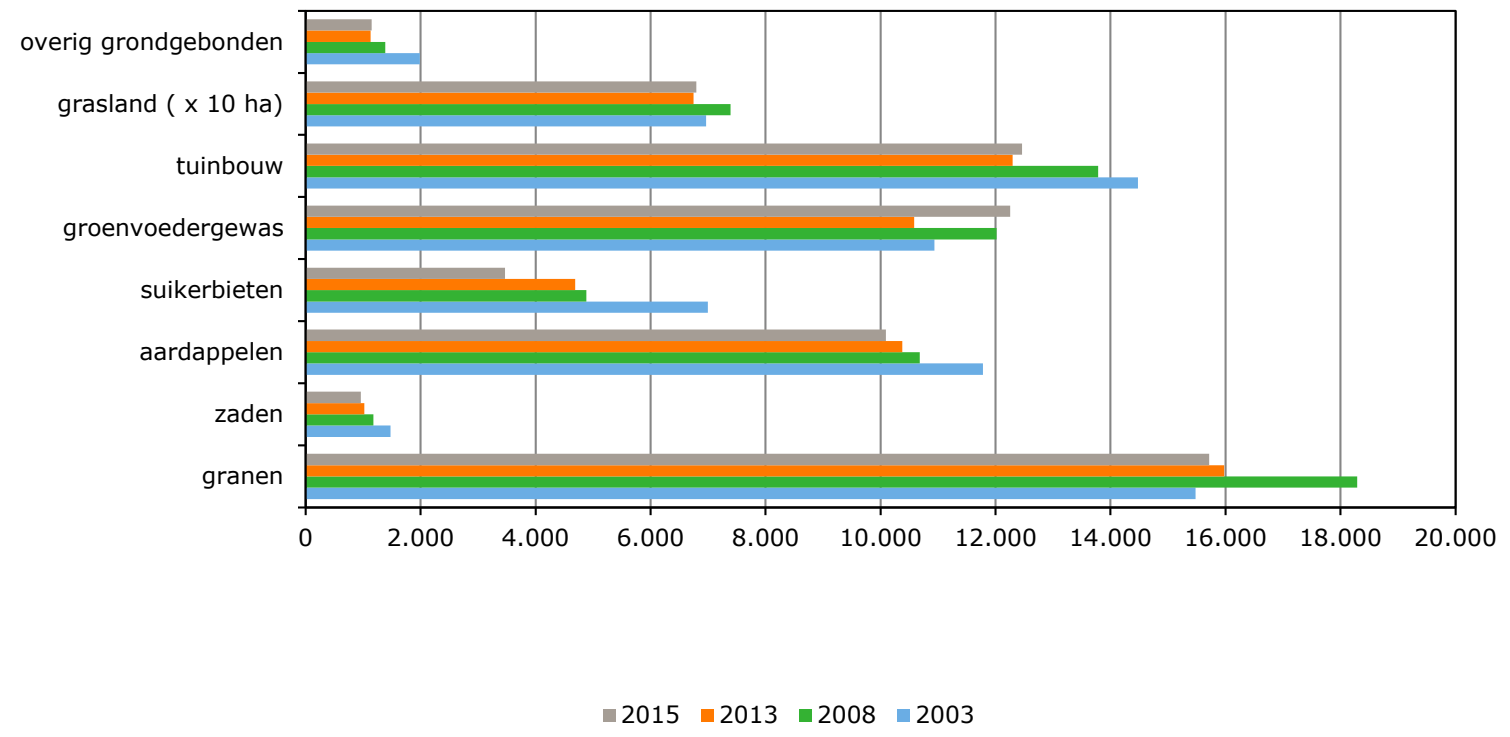

Figuur B1.2 Arealen grondgebonden gewassen in Zuid-Holland in 2003, 2008, 2013 en 2015 (ha) 


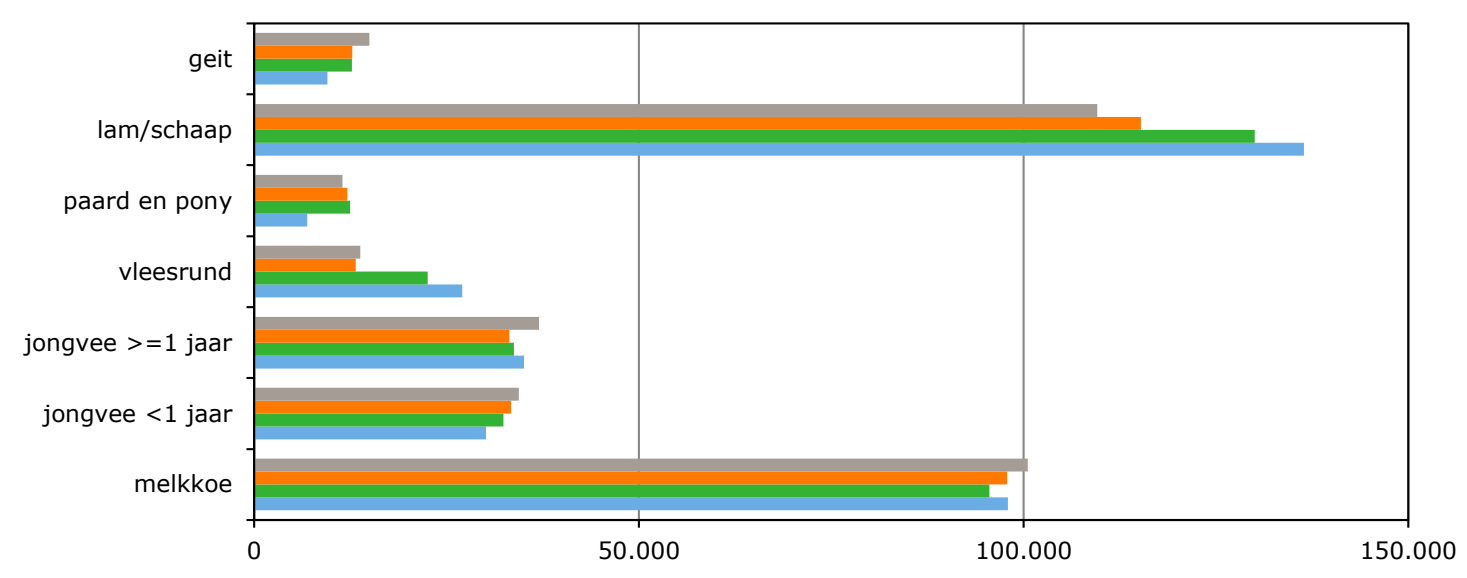

- $2015-2013=2008-2003$

Figuur B1.3 Omvang van de veestapel naar diersoort in Zuid Holland in 2003, 2008, 2013 en 2015.

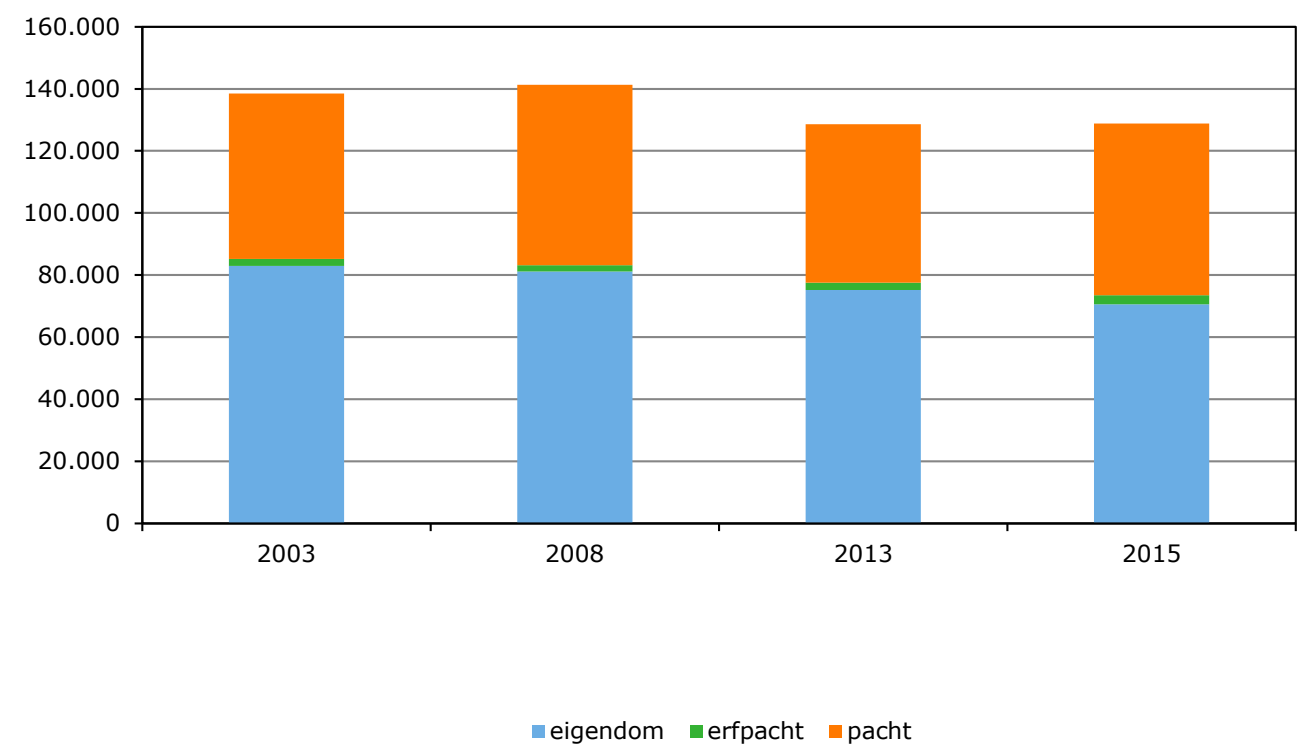

Figuur B1.4 Eigendom/pacht in 2003, 2008, 2013 en 2015 in Zuid-Holland (grondgebonden landbouw) 


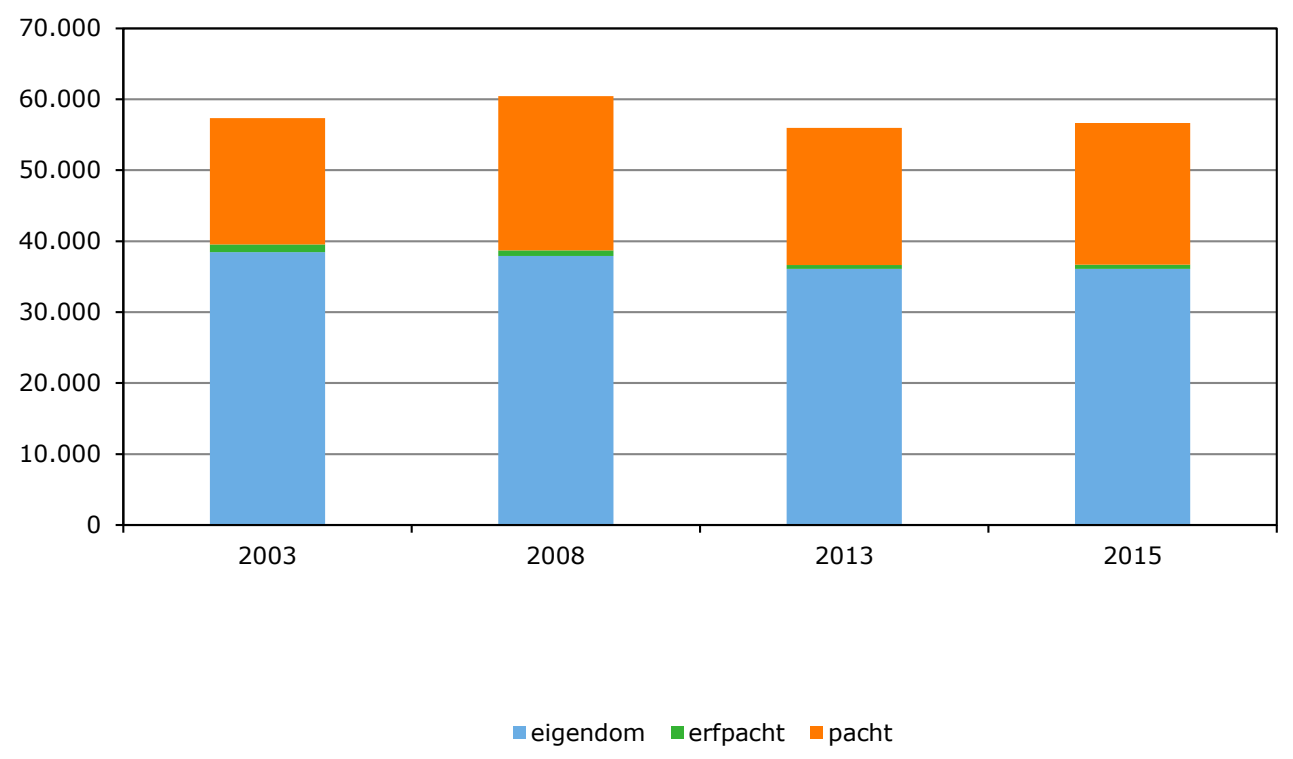

Figuur B1.5 Eigendom/pacht in 2003, 2008, 2013 en 2015 in Zuid-Holland (melkveehouderij)

\section{Tabel B1.1}

Aandelen eigendom, erfpacht en pacht in 2003, 2008, 2013 en 2015 in Zuid-Holland in de melkveehouderij

\begin{tabular}{lrrrr} 
Vorm & 2003 & 2008 & 2013 & 2015 \\
Eigendom (ha) & 38.473 & 37.929 & 36.098 & 36.090 \\
\hline Erfpacht (ha) & 1.056 & 751 & 526 & 582 \\
\hline Pacht (ha) & 17.827 & 21.759 & 19.344 & 19.995 \\
\hline Totaal (ha) & 57.356 & 60.439 & 55.969 \\
\hline
\end{tabular}

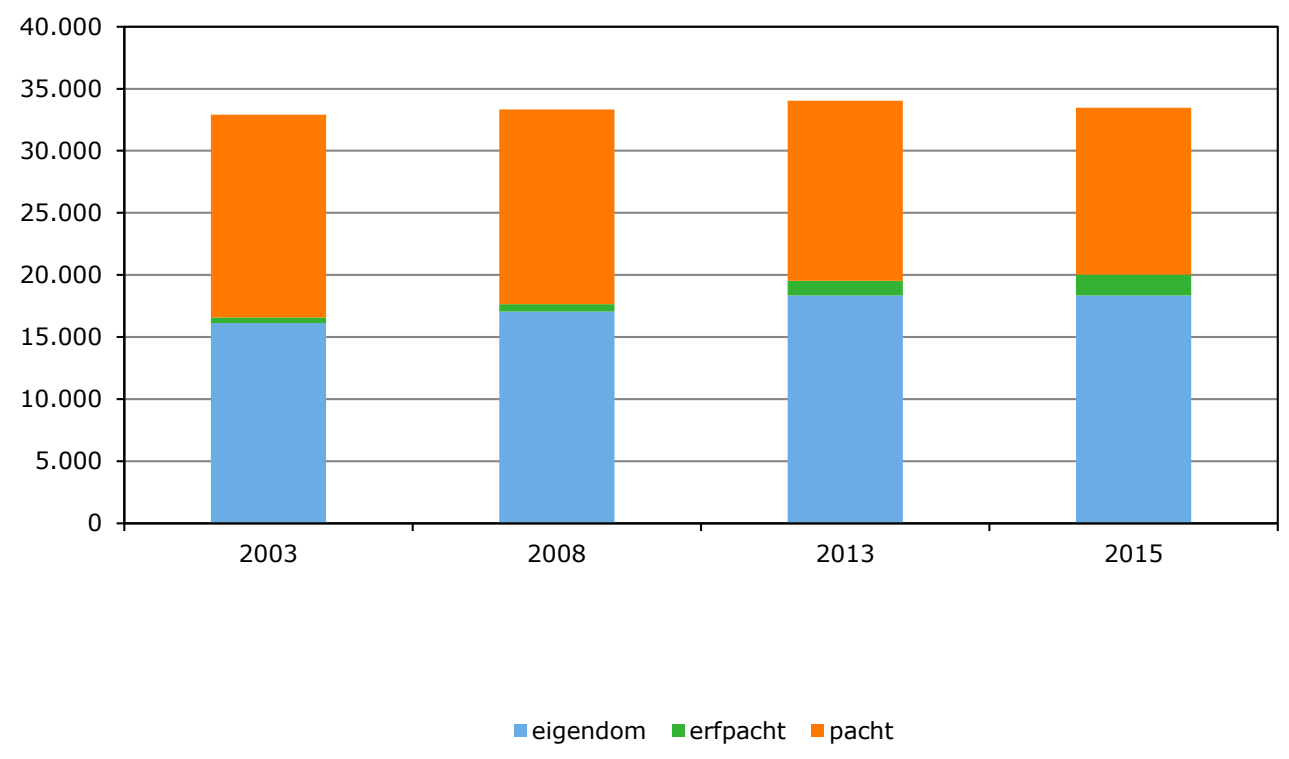

Figuur B1.6 Eigendom/pacht in 2003, 2008, 2013 en 2015 in Zuid-Holland (akkerbouw) 
Tabel B1.2

Aandelen eigendom, erfpacht en pacht in 2003, 2008, 2013 en 2015 in Zuid-Holland in de akkerbouw

\begin{tabular}{lrrrr} 
Vorm & 2003 & 2008 & 2013 & 2015 \\
Eigendom (ha) & 16.123 & 17.068 & 18.347 & 18.336 \\
\hline Erfpacht (ha) & 457 & 572 & 1.177 & 1.693 \\
\hline Pacht (ha) & 16.320 & 15.691 & 14.511 & 3.446 \\
\hline Totaal (ha) & 32.900 & 33.331 & 33.475 \\
\hline
\end{tabular}

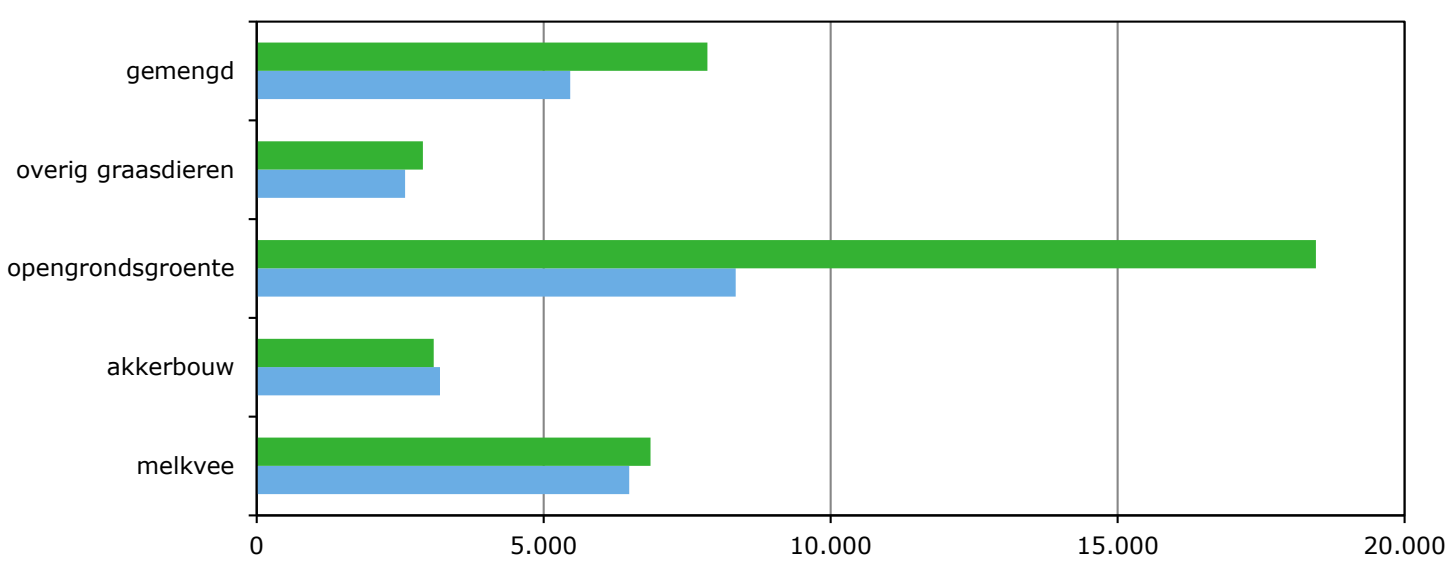

nederland $\quad$ Zuid-Holland

Figuur B1.7 Intensiteit, uitgedrukt in euro Standaardopbrengst (SO) per hectare, naar bedrijfstype in Zuid-Holland en Nederland, 2015

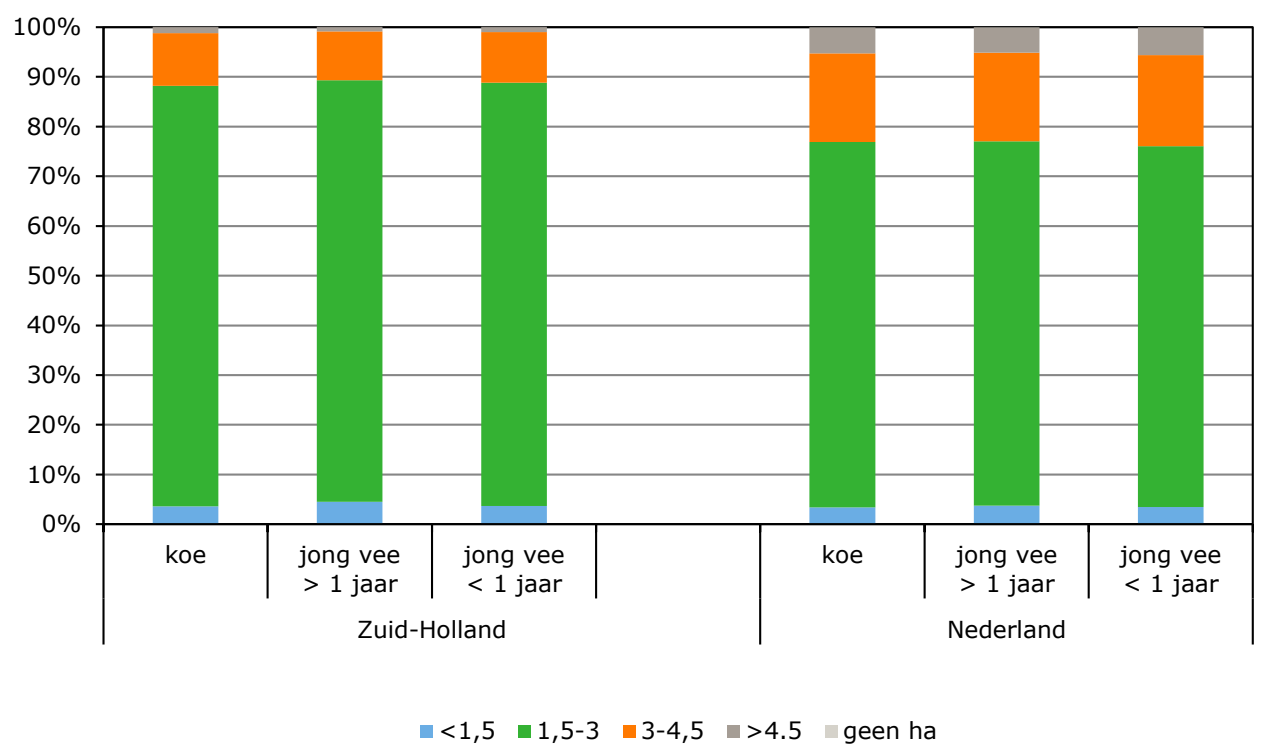

Figuur B1.8 Opbouw van de rundveestapel naar intensiteitsklasse (gve/ha) in Zuid-Holland en Nederland in 2014 


\section{Bijlage 2 Standaardopbrengst (SO) als maat voor de economische bedrijfsomvang in de land- en tuinbouw}

De SO-norm is een gestandaardiseerde opbrengst (in euro) per ha of per dier die met een gewas of diercategorie gemiddeld op jaarbasis wordt behaald. Opbrengsten uit bedrijfstoeslagen en subsidies zijn niet in de norm meegenomen en voor biologische productiemethoden zijn geen aparte normen opgesteld. De SO-norm wordt vastgesteld voor elk agrarisch product dat in de Landbouwtelling wordt opgevraagd. De agrarische producten van de Landbouwtelling van 2015, met hun normen, voorwaarden en coderingen kunnen hier gevonden worden: www3.lei.wur. nl/neg/NormenSO.aspx.

De SO-normen zijn gebaseerd op genormaliseerde vijfjaargemiddelde opbrengsten. De normen worden door LEI Wageningen UR vastgesteld in elk jaar dat Eurostat de Farm Structure Survey (FSS) uitvoert. Tussentijds kunnen wijzigingen plaatsvinden door aanpassingen in de lijst van producten die in de Landbouwtelling worden gevraagd. Voor de Landbouwtelling van 2015 zijn de normen van prijsniveau 2010 gebruikt. Deze normen zijn gebaseerd op opbrengsten en prijzen uit de jaren 20082012 In 2016 worden weer nieuwe normen berekend en beschikbaar gesteld.

De SO is niet vergelijkbaar met de nge. Deze laatste is gebaseerd op het saldo van een gewas of dier. De verhouding tussen SO en nge per gewas of dier verschilt sterk. In de intensieve veehouderij zijn de toegerekende kosten per dier (met name voer) erg groot terwijl in de akkerbouw veel vaste kosten gemaakt worden die niet in de nge zijn opgenomen. Door de verschillende verhoudingen tussen SO en nge vallen door de omschakeling van de nge- naar de So-typering bedrijven eerder onder de categorie 'intensief veehouderijbedrijf;' het aandeel in de opbrengsten is namelijk groter dan het aandeel in het saldo in vergelijking met bijvoorbeeld gewassen.

Het voordeel van SO's per bedrijf en per hectare is dat ze over alle bedrijfstypen kunnen worden vergeleken. Dit is bij bijvoorbeeld de gve niet het geval. Het aantal gve/ha is bruikbaar om de veeintensiteit te duiden. Over het algemeen geldt dat hoge SO-normen voor gewassen gepaard gaan met een hoge teelt- en bewerkingsintensiteit.

Meer achtergronden van de SO-normen en typering zie http://edepot.wur. $\mathrm{hl} / 347875$ (NSO-typering 2015 Typering van agrarische bedrijven in Nederland). 


\section{Bijlage 3 Achtergrondinformatie bij de input-outputanalyse in hoofdstuk 3}

Het agrocluster wordt in de rapportages van het LEI onderverdeeld in zes deelclusters, die zijn opgebouwd uit de volgende primaire en verwerkende sectoren:

1. Akkerbouwcluster: primaire akkerbouwsector en de verwerkende bedrijven van akkerbouwproducten: aardappelen, suikerbieten, granen, cacao, koffie, thee, plantaardige vetten en oliën;

2. Opengrondstuinbouwcluster: primaire sectoren (groenten in opengrond, bloembollen, fruit, boomkwekerij) en groente- en fruitverwerkende industrie;

3. Glastuinbouwcluster: primaire sectoren (glasgroenten, snijbloemen, planten, champignons) en de groente- en fruitverwerkende industrie;

4. Grondgebonden veehouderijcluster: primaire sectoren (rundveehouderij, schapen-en geitenhouderij) en de verwerkende bedrijven (zuivelindustrie, slachterijen);

5. Intensieve veehouderijcluster: primaire sectoren (vleeskalveren-, vleeskuikens, leghennen en varkenshouderij) en de slachterijen;

6. Visserijcluster: primaire visserijsector en de visverwerkende industrie.

De directe bijdrage van deze afzonderlijke clusters aan de toegevoegde waarde en de werkgelegenheid van de nationale economie en de economie van Zuid-Holland is eenvoudig te bepalen door het optellen van de beschikbare informatie in databronnen bij CBS, Stichting LISA en LEI. Veel lastiger is het om te bepalen hoeveel toegevoegde waarde en werkgelegenheid er indirect wordt gecreëerd bij toeleverende bedrijven. Hiervoor biedt de input-outputanalyse die op het LEI gebruikt wordt, een oplossing. Wel moet in geval van Zuid-Holland eerst nog bepaald worden hoeveel er uit toeleverende bedrijven uit de provincie zelf komt en hoeveel van bedrijven in andere provincies. Sommige toeleverende sectoren komen in Zuid-Holland helemaal niet voor, terwijl er door de verschillende landbouwsectoren wel een beroep op deze sectoren wordt gedaan. Om dit inzichtelijk te maken worden de resultaten uit de input-outputanalyse hiervoor gecorrigeerd.

De betekenis van het agrocluster kan op twee manieren worden weergegeven. Bij het LEI worden de zogenoemde 'ruime' definitie en de 'enge' definitie gebruikt. De enge definitie houdt voor de afbakening van de voedings- en genotmiddelenindustrie alleen rekening met de verwerking van in Zuid-Holland geproduceerde agrarische producten terwijl de ruime definitie de gehele voedings- en genotmiddelenindustrie meeneemt ongeacht de herkomst van de agrarische grondstoffen. Dit betekent dat de in Zuid-Holland gevestigde fruitverwerkende industrie voor $100 \%$ wordt meegenomen, ook al komt misschien een deel van het fruit uit andere provincies of zelf uit het buitenland. In deze studie gaan wij uit van de ruime definitie. 
LEI Wageningen UR

Postbus 29703

2502 LS Den Haag

T 0703358330

E publicatie.lei@wur.nl

www.wageningenUR.nl/lei

\section{Rapport}

LEI 2016-066

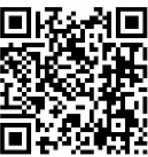

LEI Wageningen UR is een onafhankelijk, internationaal toonaangevend, sociaaleconomisch onderzoeksinstituut. De unieke data, modellen en kennis van het LEI bieden opdrachtgevers op vernieuwende wijze inzichten en integrale adviezen bij beleid en besluitvorming, en dragen uiteindelijk bij aan een duurzamere wereld. Het LEI maakt deel uit van Wageningen UR (University \& Research centre). Daarbinnen vormt het samen met het Departement Maatschappijwetenschappen van Wageningen University en het Wageningen UR Centre for Development Innovation de Social Sciences Group.

De missie van Wageningen UR (University \& Research centre) is 'To explore the potential of nature to improve the quality of life'. Binnen Wageningen UR bundelen 9 gespecialiseerde onderzoeksinstituten van stichting DLO en Wageningen University hun krachten om bij te dragen aan de oplossing van belangrijke vragen in het domein van gezonde voeding en leefomgeving. Met ongeveer 30 vestigingen, 6.500 medewerkers en 10.000 studenten behoort Wageningen UR wereldwijd tot de aansprekende kennisinstellingen binnen haar domein. De integrale benadering van de vraagstukken en de samenwerking tussen verschillende disciplines vormen het hart van de unieke Wageningen aanpak. 

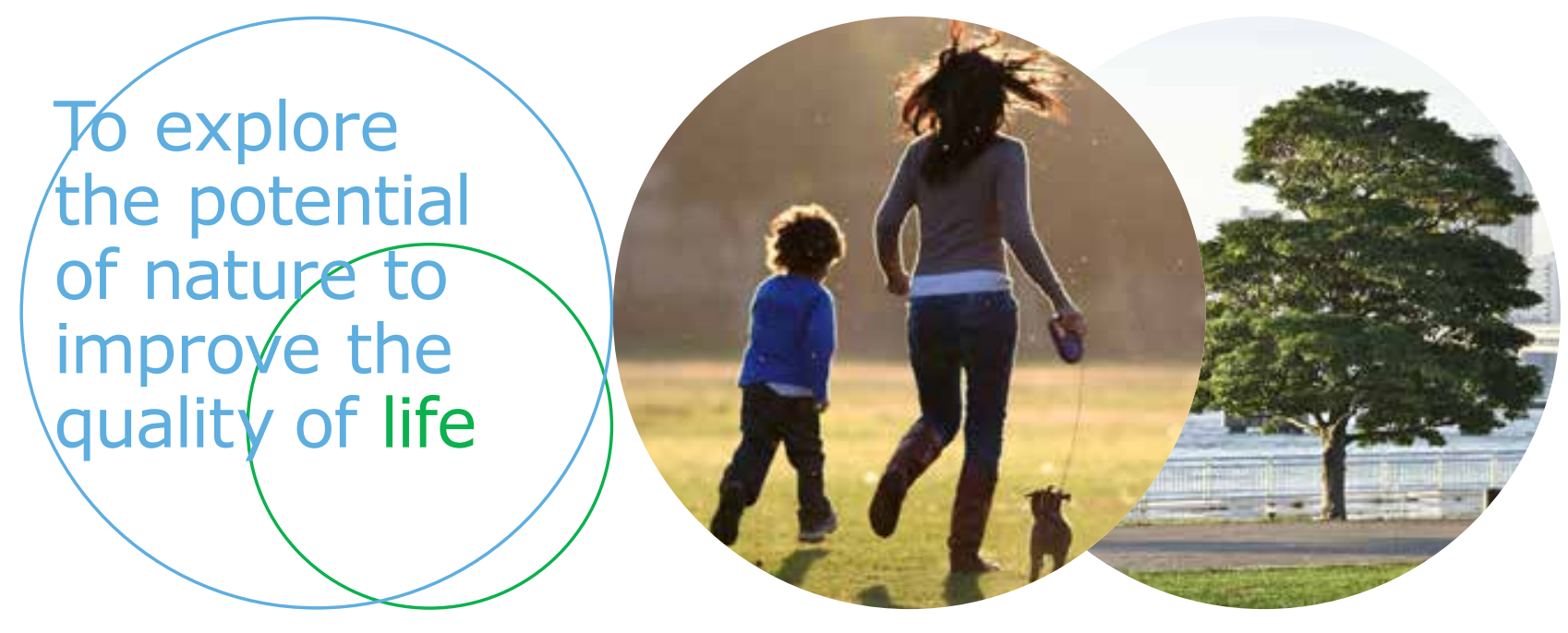

LEI Wageningen UR

Postbus 29703

2502 LS Den Haag

E publicatie.lei@wur.nl

www.wageningenUR.nl/lei

RAPPORT

LEI 2016-066

ISBN 978-94-6257-844-9
LEI Wageningen UR is een onafhankelijk, internationaal toonaangevend, sociaaleconomisch onderzoeksinstituut. De unieke data, modellen en kennis van het LEI bieden opdrachtgevers op vernieuwende wijze inzichten en integrale adviezen bij beleid en besluitvorming, en dragen uiteindelijk bij aan een duurzamere wereld. Het LEI maakt deel uit van Wageningen UR (University \& Research centre). Daarbinnen vormt het samen met het Departement Maatschappijwetenschappen van Wageningen University en het Wageningen UR Centre for Development Innovation van de Social Sciences Group.

De missie van Wageningen UR (University \& Research centre) is 'To explore the potential of nature to improve the quality of life'. Binnen Wageningen UR bundelen 9 gespecialiseerde onderzoeksinstituten van stichting DLO en Wageningen University hun krachten om bij te dragen aan de oplossing van belangrijke vragen in het domein van gezonde voeding en leefomgeving. Met ongeveer 30 vestigingen, 6.500 medewerkers en 10.000 studenten behoort Wageningen UR wereldwijd tot de aansprekende kennisinstellingen binnen haar domein. De integrale benadering van de vraagstukken en de samenwerking tussen verschillende disciplines vormen het hart van de unieke Wageningen aanpak. 